

\section{DISCLAIMER}

This report was prepared as an account of work sponsored by an agency of the United States Government. Neither the United States Government nor any agency thereof, nor any of their employees, make any warranty, express or implied, or assumes any legal liability or responsibility for the accuracy, completeness, or usefulness of any information, apparatus, product, or process disclosed, or represents that its use would not infringe privately owned rights. Reference herein to any specific commercial product, process, or service by trade name, trademark, manufacturer, or otherwise does not necessarily constitute or imply its endorsement, recommendation, or favoring by the United States Government or any agency thereof. The views and opinions of authors expressed herein do not necessarily state or reflect those of the United States Government or any agency thereof. 


\section{DISCLAIMER}

Portions of this document may be illegible in electronic image products. Images are produced from the best available original document. 
SAND 2000-0478

Unlimited Release

Printed March 2000

\title{
The Use of Carbon Fibers in Wind Turbine Blade Design: a SERI-8 Blade Example
}

\author{
Cheng-Huat Ong \& Stephen W. Tsai \\ Department of Aeronautics \& Astronautics \\ Stanford University \\ Stanford CA 94305-4035
}

Sandia Contract: BE-6196

\begin{abstract}
The benefit of introducing carbon fibers in a wind turbine blade was evaluated. The SERI-8 wind turbine blade was used as a baseline for study. A model of the blade strength and stiffness properties was created using the 3D_Beam code; the predicted geometry and structural properties were validated against available data and static test results. Different enhanced models, which represent different volumes of carbon fibers in the blade, were also studied for two design options: with and without bend-twist coupling. Our studies indicate that hybrid blades have excellent structural properties compared to the all-glass SERI-8 blade. Recurring fabrication costs were also included in the study. The cost study highlights the importance of the labor-cost to material-cost ratio in the cost benefits and penalties of fabrication of a hybrid glass and carbon blade.
\end{abstract}




\section{Acknowledgments}

This project was supported by Sandia National Laboratories under Contract No. BE-6196. The Technical Monitor is Dr. Paul S. Veers. The authors would like to thank Paul Veers and Thomas Ashwill for their participation in many beneficial discussions. The authors would like to thank James Tangler for sharing the unpublished blade cost information. 


\section{Contents}

1. SERI-8 Blade Dimensions \& Properties ................ 1

2. SERI-8 Blade Baseline Model ................................ 10

3. SERI-8 Blade Enhanced Models $\ldots \ldots \ldots \ldots \ldots \ldots \ldots \ldots \ldots . \ldots \ldots$

4. Cost Estimates for the SERI-8 Blade ….................... 54

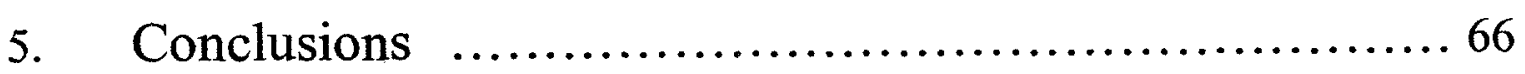

References ..................................................... 68 


\section{Chapter 1}

\section{SERI-8 Blade Dimensions \& Properties}

A SERI-8 blade is a 7.9-meter blade, which was designed by the Solar Energy Research Institute (SERI, now called the National Renewable Energy Laboratory, NREL). SERI developed a set of thin airfoils (S806A, S805A, S807 and S808) that were incorporated into a 7.9-meter blade, which was geometrically optimized for a $65 \mathrm{KW}$ wind turbine [i]. The SERI- 8 blades were designed as replacement blades for Aerostar 7.5-meter blades, which are based on the NACA $44 \mathrm{xx}$ series airfoils. The differences in geometry between Aerostar blades and SERI-8 blades are given in Tangler et al. [1] and Keller and Smith [2].

We have summarized here pertinent data from Tangler et al. [1], Keller and Smith [2], Jackson [3] and Klingenstein [4], and it was used to generate the SERI-8 baseline finite element model (the code used is 3D-Beam [5]). The structural properties read out from the references were used to validate the SERI-8 finite element model.

\subsection{Shape \& Dimensions}

A SERI-8 blade has various airfoil shapes along its span. The normalized coordinates of these thin airfoil shapes are given in Table 1.1. Table 1.2 provides the span location and chord length of a specific airfoil shape. The initial twist distribution is also given in Table 1.2. Figure 1.1 shows the general dimensions of a SERI-8 blade; the figure also highlights the shape change. 


\subsection{Section Structural Properties}

The section structural properties of the SERI-8 blade are given in Table 1.3, which for the 12-station blade include mass distribution, EI (flapping), skin cross-section area, $\mathrm{I}_{\mathrm{xx}}$ (torsion), $\mathrm{I}_{\mathrm{yy}}$ (flapping), and $\mathrm{I}_{\mathrm{zz}}$ (edgewise).

\subsection{Fabrication Information}

Figure 1.2 shows the general construction of SERI- 8 blades. At the root was a steel root fitting that was about 16 inches long and attached to a filament wound transition spar that measured about 96 inches in length. A 142-inch shear web was then attached to the transition spar. The skins of the shear webs consisted of 6-ply $\pm 45^{\circ} \mathrm{E}$ glass material. The main skin of the blade was composed of MAT, TRIAX, Core and unidirectional-roving fibers. Detailed laminating information and material data could not be found for the as-built blade. We were forced to work from laminate design information that was substantially changed before fabrication and from back calculations of properties from static test results 


\begin{tabular}{|c|c|}
\hline S805A & \\
\hline 1.0000 & -0.0031 \\
\hline 0.9900 & -0.0033 \\
\hline 0.9800 & -0.0034 \\
\hline 0.9600 & -0.0035 \\
\hline 0.9400 & -0.0037 \\
\hline 0.9200 & -0.0040 \\
\hline 0.9000 & -0.0050 \\
\hline 0.8500 & -0.0111 \\
\hline 0.8000 & -0.0182 \\
\hline 0.7500 & -0.0252 \\
\hline 0.7000 & -0.0316 \\
\hline 0.6500 & -0.0370 \\
\hline 0.6000 & -0.0411 \\
\hline 0.5500 & -0.0438 \\
\hline 0.5000 & -0.0455 \\
\hline 0.4500 & -0.0460 \\
\hline 0.4000 & -0.0462 \\
\hline 0.3500 & -0.0455 \\
\hline 0.3000 & -0.0440 \\
\hline 0.2500 & -0.0418 \\
\hline 0.2000 & -0.0388 \\
\hline 0.1500 & -0.0348 \\
\hline 0.1200 & -0.0318 \\
\hline 0.1000 & -0.0294 \\
\hline 0.0800 & -0.0268 \\
\hline 0.0600 & -0.0236 \\
\hline 0.0500 & -0.0218 \\
\hline 0.0400 & -0.0198 \\
\hline 0.0300 & -0.0174 \\
\hline 0.0199 & -0.0143 \\
\hline 0.0100 & -0.0106 \\
\hline 0.0030 & -0.0062 \\
\hline 0.0000 & -0.0003 \\
\hline 0.0027 & 0.0073 \\
\hline 0.0100 & 0.0158 \\
\hline 0.0199 & 0.0233 \\
\hline 0.0299 & 0.0291 \\
\hline 0.0400 & 0.0342 \\
\hline 0.0499 & 0.0385 \\
\hline 0.0600 & 0.0424 \\
\hline 0.0800 & 0.0492 \\
\hline 0.1000 & 0.0550 \\
\hline 0.1200 & 0.0601 \\
\hline 0.1500 & 0.0666 \\
\hline 0.2000 & 0.0751 \\
\hline 0.2500 & 0.0814 \\
\hline 0.3000 & 0.0858 \\
\hline 0.3500 & 0.0883 \\
\hline 0.4000 & 0.0889 \\
\hline 0.4500 & 0.0873 \\
\hline 0.5000 & 0.0834 \\
\hline 0.5500 & 0.0776 \\
\hline 0.6000 & 0.0705 \\
\hline 0.6500 & 0.0627 \\
\hline 0.7000 & 0.0546 \\
\hline 0.7500 & 0.0463 \\
\hline 0.8000 & 0.0378 \\
\hline 0.8500 & 0.0292 \\
\hline 0.9000 & 0.0201 \\
\hline 0.9200 & 0.0167 \\
\hline 0.9400 & 0.0133 \\
\hline 0.9600 & 0.0099 \\
\hline 0.9800 & 0.0065 \\
\hline 0.9900 & 0.0048 \\
\hline 1.0000 & 0.0031 \\
\hline
\end{tabular}

\begin{tabular}{|c|c|}
\hline \multicolumn{2}{|c|}{ S805A/S806A } \\
\hline 1.0000 & -0.0035 \\
\hline 0.9900 & -0.0037 \\
\hline 0.9800 & -0.0039 \\
\hline 0.9600 & -0.0042 \\
\hline 0.9400 & -0.0045 \\
\hline 0.9200 & -0.0050 \\
\hline 0.9000 & -0.0059 \\
\hline 0.8500 & -0.0114 \\
\hline 0.8000 & -0.0172 \\
\hline 0.7500 & -0.0227 \\
\hline 0.7000 & -0.0275 \\
\hline 0.6500 & -0.0314 \\
\hline 0.6000 & -0.0343 \\
\hline 0.5500 & -0.0363 \\
\hline 0.5000 & -0.0375 \\
\hline 0.4500 & -0.0381 \\
\hline 0.4000 & -0.0381 \\
\hline 0.3500 & -0.0376 \\
\hline 0.3000 & -0.0365 \\
\hline 0.2500 & -0.0349 \\
\hline 0.2000 & -0.0326 \\
\hline 0.1500 & -0.0295 \\
\hline 0.1200 & -0.0271 \\
\hline 0.1000 & -0.0253 \\
\hline 0.0800 & -0.0232 \\
\hline 0.0600 & -0.0207 \\
\hline 0.0500 & -0.0192 \\
\hline 0.0400 & -0.0176 \\
\hline 0.0300 & -0.0156 \\
\hline 0.0200 & -0.0130 \\
\hline 0.0100 & -0.0098 \\
\hline 0.0030 & -0.0059 \\
\hline 0.0000 & -0.0001 \\
\hline 0.0027 & 0.0071 \\
\hline 0.0100 & 0.0153 \\
\hline 0.0199 & 0.0225 \\
\hline 0.0299 & 0.0281 \\
\hline 0.0400 & 0.0329 \\
\hline 0.0499 & 0.0370 \\
\hline 0.0600 & 0.0407 \\
\hline 0.0800 & 0.0472 \\
\hline 0.1000 & 0.0528 \\
\hline 0.1200 & 0.0576 \\
\hline 0.1500 & 0.0639 \\
\hline 0.2000 & 0.0722 \\
\hline 0.2500 & 0.0784 \\
\hline 0.3000 & 0.0828 \\
\hline 0.3500 & 0.0856 \\
\hline 0.4000 & 0.0868 \\
\hline 0.4500 & 0.0861 \\
\hline 0.5000 & 0.0836 \\
\hline 0.5500 & 0.0791 \\
\hline 0.6000 & 0.0729 \\
\hline 0.6500 & 0.0653 \\
\hline 0.7000 & 0.0567 \\
\hline 0.7500 & 0.0474 \\
\hline 0.8000 & 0.0380 \\
\hline 0.8500 & 0.0286 \\
\hline 0.9000 & 0.0191 \\
\hline 0.9200 & 0.0157 \\
\hline 0.9400 & 0.0126 \\
\hline 0.9600 & 0.0095 \\
\hline 0.9800 & 0.0065 \\
\hline 0.9900 & 0.0050 \\
\hline 1.0000 & 0.0035 \\
\hline
\end{tabular}

\begin{tabular}{|c|c|}
\hline \multicolumn{2}{|c|}{ S805A/S807 } \\
\hline 1.0000 & -0.0028 \\
\hline 0.9900 & -0.0025 \\
\hline 0.9800 & -0.0021 \\
\hline 0.9600 & -0.0013 \\
\hline 0.9400 & -0.0005 \\
\hline 0.9200 & -0.0001 \\
\hline 0.9000 & -0.0004 \\
\hline 0.8500 & -0.0053 \\
\hline 0.8000 & -0.0118 \\
\hline 0.7500 & -0.0190 \\
\hline 0.7000 & -0.0266 \\
\hline 0.6500 & -0.0342 \\
\hline 0.6000 & -0.0416 \\
\hline 0.5500 & -0.0484 \\
\hline 0.5000 & -0.0547 \\
\hline 0.4500 & -0.0599 \\
\hline 0.4000 & -0.0637 \\
\hline 0.3500 & -0.0655 \\
\hline 0.3000 & -0.0651 \\
\hline 0.2500 & -0.0626 \\
\hline 0.2000 & -0.0583 \\
\hline 0.1500 & -0.0520 \\
\hline 0.1200 & -0.0471 \\
\hline 0.1000 & -0.0433 \\
\hline 0.0800 & -0.0389 \\
\hline 0.0600 & -0.0338 \\
\hline 0.0500 & .0 .0308 \\
\hline 0.0399 & -0.0276 \\
\hline 0.0300 & -0.0239 \\
\hline 0.0200 & -0.0194 \\
\hline 0.0100 & -0.0138 \\
\hline 0.0030 & -0.0078 \\
\hline 0.0000 & -0.0007 \\
\hline 0.0027 & 0.0085 \\
\hline 0.0100 & 0.0184 \\
\hline 0.0199 & 0.0272 \\
\hline 0.0299 & 0.0340 \\
\hline 0.0400 & 0.0398 \\
\hline 0.0499 & 0.0449 \\
\hline 0.0600 & 0.0494 \\
\hline 0.0800 & 0.0572 \\
\hline 0.0999 & 0.0638 \\
\hline 0.1200 & 0.0694 \\
\hline 0.1500 & 0.0762 \\
\hline 0.2000 & 0.0841 \\
\hline 0.2500 & 0.0882 \\
\hline 0.3000 & 0.0899 \\
\hline 0.3500 & 0.0898 \\
\hline 0.4000 & 0.0883 \\
\hline 0.4500 & 0.0854 \\
\hline 0.5000 & 0.0811 \\
\hline 0.5500 & 0.0756 \\
\hline 0.6000 & 0.0694 \\
\hline 0.6500 & 0.0627 \\
\hline 0.7000 & 0.0556 \\
\hline 0.7500 & 0.0481 \\
\hline 0.8000 & 0.0404 \\
\hline 0.8500 & 0.0323 \\
\hline 0.9000 & 0.0232 \\
\hline 0.9200 & 0.0193 \\
\hline 0.9400 & 0.0152 \\
\hline 0.9600 & 0.0111 \\
\hline 0.9800 & 0.0069 \\
\hline 0.9900 & 0.0049 \\
\hline 1.0000 & 0.0028 \\
\hline
\end{tabular}

\begin{tabular}{|c|c|c|c|}
\hline \multicolumn{2}{|l|}{ S806A } & \multicolumn{2}{|l|}{5807} \\
\hline 1.0000 & -0.0042 & 1.0000 & -0.0028 \\
\hline 0.9900 & -0.0044 & 0.9900 & -0.0020 \\
\hline 0.9800 & -0.0046 & 0.9800 & -0.0012 \\
\hline 0.9600 & -0.0050 & 0.9600 & 0.0007 \\
\hline 0.9400 & -0.0054 & 0.9400 & 0.0024 \\
\hline 0.9200 & -0.0059 & 0.9200 & 0.0037 \\
\hline 0.9000 & -0.0069 & 0.9000 & 0.0041 \\
\hline 0.8500 & -0.0117 & 0.8500 & 0.0005 \\
\hline 0.8000 & -0.0162 & 0.8000 & -0.0053 \\
\hline 0.7500 & -0.0202 & 0.7500 & -0.0128 \\
\hline 0.7000 & -0.0234 & 0.7000 & -0.0216 \\
\hline 0.6500 & -0.0258 & 0.6500 & -0.0315 \\
\hline 0.6000 & -0.0275 & 0.6000 & -0.0421 \\
\hline 0.5500 & -0.0287 & 0.5500 & -0.0530 \\
\hline 0.5000 & -0.0295 & 0.5000 & -0.0638 \\
\hline 0.4500 & -0.0299 & 0.4500 & -0.0736 \\
\hline 0.4000 & -0.0300 & 0.4000 & -0.0811 \\
\hline 0.3500 & -0.0297 & 0.3500 & -0.0855 \\
\hline 0.3000 & -0.0290 & 0.3000 & -0.0861 \\
\hline 0.2500 & -0.0279 & 0.2500 & -0.0834 \\
\hline 0.2000 & -0.0263 & 0.2000 & -0.0777 \\
\hline 0.1500 & -0.0242 & 0.1500 & -0.0692 \\
\hline 0.1200 & -0.0225 & 0.1200 & -0.0624 \\
\hline 0.1000 & -0.0212 & 0.1000 & -0.0571 \\
\hline 0.0800 & -0.0197 & 0.0799 & -0.0510 \\
\hline 0.0600 & -0.0177 & 0.0599 & -0.0439 \\
\hline 0.0500 & -0.0166 & 0.0500 & -0.0399 \\
\hline 0.0400 & -0.0153 & 0.0399 & -0.0354 \\
\hline 0.0300 & -0.0138 & 0.0300 & -0.0304 \\
\hline 0.0200 & -0.0116 & 0.0200 & -0.0244 \\
\hline 0.0100 & -0.0089 & 0.0100 & -0.0171 \\
\hline 0.0030 & -0.0055 & 0.0030 & -0.0093 \\
\hline 0.0000 & 0.0002 & 0.0000 & -0.0011 \\
\hline 0.0027 & 0.0069 & 0.0027 & 0.0098 \\
\hline 0.0100 & 0.0147 & 0.0099 & 0.0209 \\
\hline 0.0199 & 0.0216 & 0.0199 & 0.0310 \\
\hline 0.0299 & 0.0270 & 0.0298 & 0.0388 \\
\hline 0.0400 & 0.0315 & 0.0399 & 0.0455 \\
\hline 0.0499 & 0.0355 & 0.0499 & 0.0513 \\
\hline 0.0600 & 0.0391 & 0.0599 & 0.0564 \\
\hline 0.0800 & 0.0452 & 0.0800 & 0.0653 \\
\hline 0.1000 & 0.0506 & 0.0999 & 0.0726 \\
\hline 0.1200 & 0.0552 & 0.1199 & 0.0787 \\
\hline 0.1500 & 0.0612 & 0.1499 & 0.0859 \\
\hline 0.2000 & 0.0692 & 0.2000 & 0.0930 \\
\hline 0.2500 & 0.0754 & 0.2500 & 0.0950 \\
\hline 0.3000 & 0.0799 & 0.3000 & 0.0940 \\
\hline 0.3500 & 0.0829 & 0.3500 & 0.0913 \\
\hline 0.4000 & 0.0846 & 0.4000 & 0.0877 \\
\hline 0.4500 & 0.0850 & 0.4500 & 0.0835 \\
\hline 0.5000 & 0.0837 & 0.5000 & 0.0788 \\
\hline 0.5500 & 0.0806 & 0.5500 & 0.0737 \\
\hline 0.6000 & 0.0753 & 0.6000 & 0.0683 \\
\hline 0.6500 & 0.0680 & 0.6500 & 0.0626 \\
\hline 0.7000 & 0.0587 & 0.7000 & 0.0565 \\
\hline 0.7500 & 0.0485 & 0.7500 & 0.0500 \\
\hline 0.8000 & 0.0381 & 0.8000 & 0.0430 \\
\hline 0.8500 & 0.0279 & 0.8500 & 0.0353 \\
\hline 0.9000 & 0.0180 & 0.9000 & 0.0263 \\
\hline 0.9199 & 0.0148 & 0.9201 & 0.0220 \\
\hline 0.9399 & 0.0121 & 0.9401 & 0.0173 \\
\hline 0.9600 & 0.0094 & 0.9601 & 0.0126 \\
\hline 0.9800 & 0.0068 & 0.9801 & 0.0077 \\
\hline 0.9900 & 0.0055 & 0.9900 & 0.0052 \\
\hline 1.0000 & 0.0042 & 1.0000 & 0.0028 \\
\hline
\end{tabular}

\begin{tabular}{|c|c|}
\hline 5808 & \\
\hline 1.0000 & -0.0028 \\
\hline 0.9900 & -0.0021 \\
\hline 0.9800 & -0.0012 \\
\hline 0.9600 & 0.0006 \\
\hline 0.9400 & 0.0024 \\
\hline 0.9200 & 0.0039 \\
\hline 0.9000 & 0.0046 \\
\hline 0.8500 & 0.0014 \\
\hline 0.8000 & -0.0040 \\
\hline 0.7500 & -0.0110 \\
\hline 0.7000 & -0.0193 \\
\hline 0.6500 & -0.0287 \\
\hline 0.6000 & -0.0388 \\
\hline 0.5500 & -0.0494 \\
\hline 0.5000 & -0.0601 \\
\hline 0.4500 & -0.0707 \\
\hline 0.4000 & -0.0807 \\
\hline 0.3500 & -0.0895 \\
\hline 0.3000 & -0.0966 \\
\hline 0.2500 & -0.1008 \\
\hline 0.2000 & -0.1007 \\
\hline 0.1500 & -0.0945 \\
\hline 0.1200 & -0.0871 \\
\hline 0.1001 & -0.0805 \\
\hline 0.0800 & -0.0723 \\
\hline 0.0599 & -0.0625 \\
\hline 0.0500 & -0.0568 \\
\hline 0.0399 & -0.0503 \\
\hline 0.0300 & -0.0430 \\
\hline 0.0200 & -0.0343 \\
\hline 0.0100 & -0.0236 \\
\hline 0.0030 & -0.0125 \\
\hline 0.0001 & -0.0020 \\
\hline 0.0027 & 0.0125 \\
\hline 0.0099 & 0.0260 \\
\hline 0.0200 & 0.0381 \\
\hline 0.0300 & 0.0473 \\
\hline 0.0400 & 0.0549 \\
\hline 0.0499 & 0.0613 \\
\hline 0.0600 & 0.0671 \\
\hline 0.0800 & 0.0765 \\
\hline 0.1000 & 0.0841 \\
\hline 0.1199 & 0.0903 \\
\hline 0.1499 & 0.0975 \\
\hline 0.2000 & 0.1055 \\
\hline 0.2500 & 0.1095 \\
\hline 0.3000 & 0.1106 \\
\hline 0.3500 & 0.1094 \\
\hline 0.4000 & 0.1065 \\
\hline 0.4500 & 0.1021 \\
\hline 0.5000 & 0.0966 \\
\hline 0.5500 & 0.0901 \\
\hline 0.6000 & 0.0829 \\
\hline 0.6500 & 0.0751 \\
\hline 0.7000 & 0.0667 \\
\hline 0.7500 & 0.0578 \\
\hline 0.8000 & 0.0485 \\
\hline 0.8500 & 0.0387 \\
\hline 0.9000 & 0.0277 \\
\hline 0.9201 & 0.0229 \\
\hline 0.9401 & 0.0179 \\
\hline 0.9600 & 0.0129 \\
\hline 0.9800 & 0.0079 \\
\hline 0.9900 & 0.0054 \\
\hline 1.0000 & 0.0028 \\
\hline
\end{tabular}

Table 1.1 Normalized Airfoil Coordinates for SERI-8 Thin Airfoil Shapes

(Source: Sandia National Laboratories) 
(Rotor hub radius $=0.6 \pi, 23.62 \mathrm{in} .1 \mathrm{tt} 11.62 \mathrm{in}$ : Twist axis at $30 \%$ chord)

\begin{tabular}{|c|c|c|c|c|c|c|c|c|c|c|}
\hline $\begin{array}{c}\text { Blade } \\
\text { Station } \\
\text { No. } \\
\end{array}$ & $\begin{array}{c}\text { Blade } \\
\text { Radius } \\
\text { (in) }\end{array}$ & $\begin{array}{l}\text { Blade } \\
\text { Chord } \\
\text { c. (in) } \\
\end{array}$ & $\begin{array}{c}\text { Blade } \\
\text { Twist } \\
\text { B, (deg) }\end{array}$ & $\begin{array}{c}\text { Elade } \\
\text { Thickness } \\
t, \text { (in) }\end{array}$ & $\begin{array}{c}\text { Rotor } \\
\text { Radius } \\
\text { r. (in) } \\
\end{array}$ & $\begin{array}{c}\text { Rotor } \\
\text { Radius } \\
r,(f t) \\
\end{array}$ & $\begin{array}{c}\text { Rotor } \\
\text { Radius } \\
\text { r. (m) }\end{array}$ & $\begin{array}{c}\% \text { Rotor } \\
\text { Radius } \\
\mathbf{r} / \mathbf{R}\end{array}$ & $\begin{array}{c}\text { Chord } \\
\text { Radius } \\
\text { c/A }\end{array}$ & $\begin{array}{c}\text { Airfoil Section/ } \\
\text { Notes }\end{array}$ \\
\hline-1 & -1.38 & $\mathrm{Na}$ & $\mathrm{n} / \mathrm{a}$ & $\mathrm{n} / \mathrm{a}$ & 23.62 & 1.97 & 0.60 & 0.07 & $n / a$ & + Rotor hub radius \\
\hline 0 & 0 & 16.50 & $n / a$ & 16.50 & 25.00 & 2.08 & 0.63 & 0.07 & 0.0490 & + Blade rool Hange thik \\
\hline 1 & 6 & 17.13 & n/a & 17.13 & 31.00 & 2.58 & 0.79 & 0.09 & 0.0508 & \\
\hline 2 & 12 & 17.83 & $\mathrm{n} / \mathrm{a}$ & 17.83 & 37.00 & 3.08 & 0.94 & 0.11 & 0.0529 & \\
\hline 3 & 18 & 18.50 & $\mathrm{n} / \mathrm{a}$ & 18.50 & 43.00 & 3.58 & 1.09 & 0.13 & 0.0549 & \\
\hline 4 & 24 & 22.15 & 29.85 & 17.18 & 49.00 & 4.08 & 1.24 & 0.15 & 0.0657 & \\
\hline 5 & 30 & 25.79 & 28.03 & 15.85 & 55.00 & 4.58 & 1.40 & 0.16 & 0.0765 & \\
\hline 6 & 36 & 29.43 & 26.28 & 14.53 & 61.00 & 5.08 & 1.55 & 0.18 & 0.0873 & \\
\hline 7 & 42 & 33.08 & 24.60 & 13.21 & 67.00 & 5.58 & 1.70 & 0.20 & 0.0982 & \\
\hline 8 & 48 & 36.72 & 23.00 & 11.89 & 73.00 & 6.08 & 1.85 & 0.22 & 0.1090 & \\
\hline 9 & 54 & 40.36 & 21.46 & 10.56 & 79.00 & 6.58 & 2.01 & 0.23 & 0.1198 & \\
\hline 10 & 60 & 45.00 & 20.00 & 9.24 & 85.00 & 7.08 & 2.16 & 0.25 & 0.1306 & 5808 (@ 60.0") Max C \\
\hline 11 & 66 & 43.89 & 18.61 & 8.95 & 91.00 & 7.58 & 2.31 & 0.27 & 0.1302 & \\
\hline 12 & 72 & 43.68 & 17.28 & 8.64 & 97.00 & 8.08 & 2.46 & 0.29 & 0.1296 & \\
\hline 13 & 78 & 43.41 & 16.01 & 8.32 & 103.00 & 8.58 & 2.62 & 0.31 & 0.1288 & \\
\hline 14 & 84 & 43.09 & 14.81 & 7.99 & 109.00 & 9.08 & 2.77 & 0.32 & 0.1279 & $5807\left(@ 88.6^{\circ}\right)$ \\
\hline 15 & 90 & 42.73 & 13.67 & 7.68 & 115.00 & 9.58 & 2.92 & 0.34 & 0.1268 & \\
\hline 16 & 96 & 42.33 & 12.59 & 7.52 & 121.00 & 10.08 & 3.07 & 0.36 & 0.1256 & \\
\hline 17 & 102 & $4: .89$ & 11.57 & 7.36 & 127.00 & 10.58 & 3.23 & 0.38 & 0.1243 & \\
\hline 18 & 108 & $4: 42$ & 10.61 & 7.19 & 133.00 & 11.08 & 3.38 & 0.39 & 0.1229 & \\
\hline 19 & 114 & $\therefore 6.92$ & 9.70 & 7.01 & 139.00 & 11.58 & 3.53 & 0.41 & 0.1214 & \\
\hline 20 & 120 & 40.40 & 8.85 & 6.84 & 145.00 & 12.08 & 3.68 & 0.43 & 0.1199 & \\
\hline 21 & 126 & 25.84 & 8.04 & 6.66 & 151.00 & 12.58 & 3.84 & 0.45 & 0.1182 & \\
\hline 221 & 132 & 39.27 & 7.29 & 6.48 & 157.00 & 13.08 & 3.99 & 0.47 & 0.1165 & \\
\hline 23 & 138 & 32.66 & 6.58 & 6.30 & 163.00 & 13.58 & 4.14 & 0.48 & 0.1147 & \\
\hline 24 & 144 & 32.03 & 5.93 & 6.12 & 169.00 & 14.08 & 4.29 & 0.50 & 0.1128 & \\
\hline 25 & 150 & 37.38 & 5.31 & 5.94 & 175.00 & 14.58 & 4.44 & 0.52 & 0.1109 & \\
\hline 26 & 156 & $\varepsilon .71$ & 4.74 & 5.75 & 181.00 & 15.08 & 4.60 & 0.54 & 0.1089 & s805AR (@ 180.4") \\
\hline 27 & 162 & $3 € .02$ & 4.22 & 5.57 & 187.00 & 15.58 & 4.75 & 0.55 & 0.1069 & \\
\hline 28 & 168 & $3 \equiv .30$ & 3.73 & 5.40 & 193.00 & 16.08 & 4.90 & 0.57 & 0.1047 & \\
\hline 29 & 174 & 34.57 & 3.28 & 5.23 & 199.00 & 16.58 & 5.05 & 0.59 & 0.1026 & \\
\hline 301 & 180 & 33.81 & 2.87 & 5.06 & 205.00 & 17.08 & 5.21 & 0.61 & 0.1003 & \\
\hline 31 & 186 & 33.04 & 2.50 & 4.89 & 211.00 & 17.58 & 5.36 & 0.63 & 0.0980 & \\
\hline 321 & 192 & 32.25 & 2.16 & 4.72 & 217.00 & 18.08 & 5.51 & 0.64 & 0.0957 & \\
\hline 33 & 198 & $3: .44$ & 1.85 & 4.55 & 223.00 & 18.58 & 5.66 & 0.66 & 0.0933 & \\
\hline 34 & 2041 & s.5. 51 & 1.57 & 4.38 & 229.00 & 19.08 & 5.82 & 0.68 & 0.0908 & \\
\hline 351 & 210 & $2 \equiv .76$ & 1.33 & 4.21 & 235.00 & 19.58 & 5.97 & 0.70 & 0.0883 & \\
\hline
\end{tabular}

Table 1.2 SERI-8 Blade Planform Geometry Data [2] 
(Rotor hub radius $=0.6 \mathrm{~m}, 23.62$ in, $1 \mathrm{ft} 11.62$ in; Twist axis at $30 \%$ chord)

\begin{tabular}{|c|c|c|c|c|c|c|c|c|c|c|}
\hline $\begin{array}{c}\text { Blade } \\
\text { Station } \\
\text { No. } \\
\end{array}$ & $\begin{array}{c}\text { Blade } \\
\text { Radius } \\
\text { (in) }\end{array}$ & $\begin{array}{l}\text { Blace } \\
\text { Cherd } \\
c, \text { (in) } \\
\end{array}$ & $\begin{array}{c}\text { Blade } \\
\text { Twist } \\
\text { B. (deg) }\end{array}$ & $\begin{array}{c}\text { Blace } \\
\text { Thickness } \\
t, \text { (in) }\end{array}$ & $\begin{array}{c}\text { Rotor } \\
\text { Radius } \\
r_{1} \text { (in) }\end{array}$ & $\begin{array}{c}\text { Rotor } \\
\text { Radius } \\
r .(f t) \\
\end{array}$ & $\begin{array}{c}\text { Rotor } \\
\text { Radius } \\
\text { r. (m) }\end{array}$ & $\begin{array}{c}\% \text { Rotor } \\
\text { Radius } \\
\text { rf }\end{array}$ & $\begin{array}{c}\text { Chord } \\
\text { Radius } \\
d R\end{array}$ & $\begin{array}{c}\text { Airfoil Section/ } \\
\text { Notes }\end{array}$ \\
\hline 36 & 216 & 28.90 & 1.11 & 4.03 & 241.00 & 20.08 & 6.12 & 0.72 & 0.0858 & \\
\hline 37 & 222 & 28.02 & 0.91 & 3.86 & 247.00 & 20.58 & 6.27 & 0.73 & 0.0831 & \\
\hline 38 & 228 & 27.13 & 0.74 & 3.70 & 253.00 & 21.08 & 6.43 & 0.75 & 0.0805 & S805A (@ 232.2") \\
\hline 39 & 234 & 26.21 & 0.59 & 3.53 & 259.00 & 21.58 & 6.58 & 0.77 & 0.0778 & \\
\hline 40 & 240 & 25.29 & 0.47 & 3.35 & 265.00 & 22.08 & 6.73 & 0.79 & 0.0750 & \\
\hline 41 & 246 & 24.34 & 0.36 & 3.18 & 271.00 & 22.58 & 6.88 & 0.80 & 0.0722 & \\
\hline 42 & 252 & 23.38 & 0.27 & 3.01 & 277.00 & 23.08 & 7.04 & 0.82 & 0.0694 & To slitline at $252^{\circ}$ \\
\hline 43 & 258 & 22.41 & 0.20 & 2.85 & 283.00 & 23.58 & 7.19 & 0.84 & 0.0665 & \\
\hline 44 & 264 & 21.42 & 0.14 & 2.68 & 289.00 & 24.08 & 7.34 & 0.86 & 0.0636 & S805A6A (@ 263.8") \\
\hline 45 & 270 & 20.42 & 0.09 & 2.52 & 295.00 & 24.58 & 7.49 & 0.88 & 0.0606 & \\
\hline 46 & 276 & 19.40 & 0.06 & 2.35 & 301.00 & 25.08 & 7.65 & 0.89 & 0.0576 & \\
\hline 47 & 282 & 18.37 & 0.03 & 2.19 & 307.00 & 25.58 & 7.80 & 0.91 & 0.0545 & \\
\hline 48 & 288 & 37.32 & 0.02 & 2.04 & 313.00 & 26.08 & 7.95 & 0.93 & 0.0514 & \\
\hline 49 & 294 & 16.25 & 0.01 & 1.88 & 319.00 & 26.58 & 8.10 & 0.95 & 0.0482 & S806A (@ 296.0 \\
\hline 50 & 300 & 15.19 & 0.00 & 1.75 & 325.00 & 27.08 & 8.25 & 0.96 & 0.0451 & \\
\hline 511 & 306 & 14.10 & 0.00 & 1.62 & 331.00 & 27.58 & 8.41 & 0.98 & 0.0418 & \\
\hline 52 & 312 & 13.00 & 0.00 & 1.50 & 337.00 & 28.08 & 8.56 & 1.00 & 0.0386 & S806A (@ 3i2.0") \\
\hline
\end{tabular}

Table 1.2 (continue) SERI-8 Blade Planform Geometry Data [2] 


\section{SERI $7.9 \mathrm{~m}$ Thin Airfoil Blade}

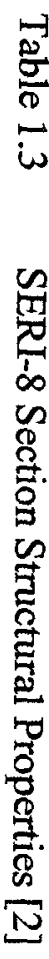

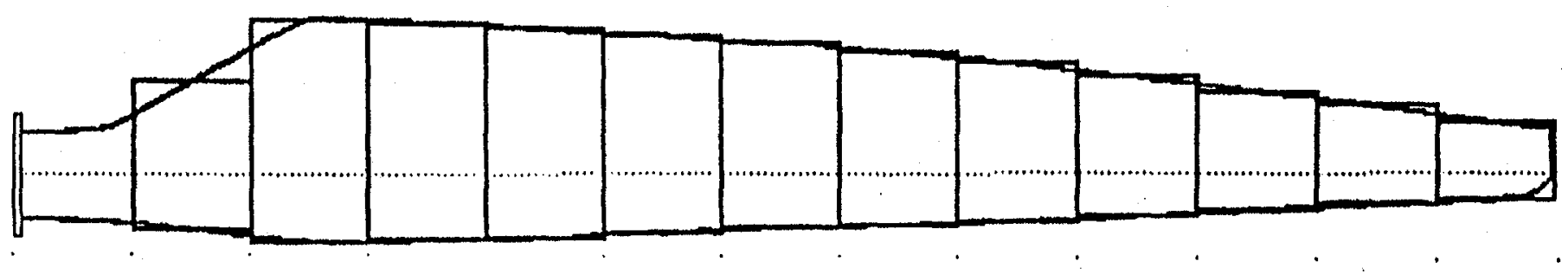

\begin{tabular}{|c|c|c|c|c|c|c|c|c|c|c|c|c|c|}
\hline Part & 1 & 2 & 3 & 4 & 5 & 6 & 7 & 8 & 9 & 10 & 11 & 12 & 13 \\
\hline Station, in & 12 & 36 & 60 & 84 & 108 & 132 & 156 & 180 & 204 & 228 & 252 & 276 & 300 \\
\hline Min. $m$ & 0.000 & 0.610 & 1.219 & 1.829 & 2.438 & 3.048 & 3.658 & 4.267 & 4.877 & 5.486 & .096 & 6.706 & 7.315 \\
\hline$m$ & 0.305 & 0.914 & 1.524 & 2.134 & 2.743 & 3.353 & 3.962 & 4.572 & 5.182 & 5.791 & 6.401 & 7.010 & 7.620 \\
\hline$a x, m$ & 0.610 & 1.219 & 1.829 & 2.438 & 3.048 & 3.658 & 4.267 & 4.877 & 5.486 & 6.096 & 6.706 & 7.315 & 7.925 \\
\hline s. $16 m$ & 184.09 & 67.05 & 62.64 & 49.13 & 36.38 & 31.10 & 28.72 & 25.75 & 27.75 & 38.41 & 53.85 & 27.18 & 10.35 \\
\hline $\mathrm{kg}$ & B3.50 & 30.41 & 28.41 & 22.28 & 16.50 & 14.11 & 13.03 & 11.68 & 12.59 & 17.42 & 24.43 & 12.33 & 4.69 \\
\hline in & 17.83 & 29.43 & 44.00 & 43.09 & 41.42 & 39.27 & 36.71 & & 30 & & 23.38 & 19.40 & 15.19 \\
\hline 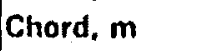 & 0.453 & 0.748 & 1.118 & 1.094 & 1.052 & 0.997 & 0.932 & 0.859 & 0.777 & 0.689 & 0.594 & 0.493 & 0.386 \\
\hline oss, $m$ & 0.453 & 0.369 & 0.235 & 0.203 & 0.183 & 0.165 & 0.146 & 0.129 & 0.111 & 0.094 & 0.076 & 0.060 & 0.044 \\
\hline Thick, m & 0.226 & 0.185 & 0.117 & 0.101 & 0.091 & 0.082 & 0.073 & 64 & 0.056 & 0.047 & 0.038 & 0.030 & 0.022 \\
\hline k/Chord & 1.000 & 0.494 & 0.210 & 0.185 & 0.174 & 0.165 & 0.157 & 0.150 & 0.143 & & 0.129 & 0.121 & 0.115 \\
\hline loe, $m$ & 0.226 & 0.289 & 0.346 & 0.331 & 0.319 & 0.300 & 0.263 & 0.258 & 0.242 & 0. & 0.181 & 0.162 & 0.123 \\
\hline lge, m & 0.226 & 0.459 & 0.772 & 0.7 & 0.733 & 0.697 & 0.663 & 0.601 & 0.535 & 0.481 & 0.413 & 0.331 & 0.263 \\
\hline $\log$ & 29.85 & 26.28 & 20.00 & 14.81 & 10.61 & 7.29 & 4.74 & 2.87 & 1.57 & 0.74 & 0.27 & 0.06 & 0.00 \\
\hline 90.Twist & 60.15 & 63.72 & 70.00 & 75.19 & 73.39 & 82.71 & 85.26 & 87.13 & 88.43 & 89.26 & 89.73 & 89.94 & 90.00 \\
\hline TOp-TE-Yr & 0.084 & 0.329 & 0.685 & 0.712 & 0.704 & 0.681 & 0.655 & 0.597 & 0.534 & 0.480 & 0.413 & 0.331 & 0.263 \\
\hline Top-TE-Zr & -0.309 & 0.368 & -0.374 & -0.293 & .0 .225 & -0.170 & -0.128 & -0.094 & .0 .070 & -0.053 & -0.040 & -0.030 & -0.022 \\
\hline
\end{tabular}




\section{SERI 7.9m Thin Airfoil Blade Stiffness Properties}

\begin{tabular}{|c|c|c|c|c|c|c|c|c|c|c|c|c|c|}
\hline Part & 1 & 2 & 3 & 4 & 5 & 6 & 7 & 8 & 9 & 10 & 11 & 12 & 13 \\
\hline Beam mld, in & 0 & 24 & 48 & 72 & 96 & 120 & 144 & 168 & 192 & 216 & 240 & 264 & 288 \\
\hline Beam mid, $m$ & .0 .305 & 0.305 & 0.914 & 1.524 & 2.134 & 2.743 & 3.353 & 3.962 & 4.572 & 5.182 & 5.791 & 6.401 & 7.010 \\
\hline Area, in ${ }^{-2} 2$ & 312.72 & 298.72 & 342.73 & 296.26 & 249.88 & 216.92 & 182.70 & 149.64 & 119.49 & 91.43 & 66.51 & 45.06 & 27.74 \\
\hline Aroa, $m \cdot 2$ & 0.2018 & 0.1927 & 0.2211 & 0.1911 & 0.1612 & 0.1399 & 0.1179 & 0.0965 & 0.0771 & 0.0590 & 0.0429 & 0.0291 & 0.0179 \\
\hline El. Flap, Ibt.in $2 \times 10+7$ & 137.00 & 331.00 & 375.00 & 114.00 & 69.30 & 52.00 & 42.70 & 34.60 & 23.30 & 10.50 & 2.17 & 2.17 & 2.17 \\
\hline El-Flop, $N-m^{-2} 2 \times 10+5$ & 39.32 & 94.99 & 107.62 & 32.72 & 19.89 & 14.92 & 12.25 & 9.93 & 6.69 & 3.01 & 0.62 & 0.62 & 0.62 \\
\hline Halt Chord, m & 0.226 & 0.374 & 0.559 & 0.547 & 0.526 & 0.499 & 0.466 & 0.429 & 0.389 & 0.345 & 0.297 & 0.246 & 0.193 \\
\hline Haif Thick, m & 0.226 & 0.185 & 0.117 & 0.101 & 0.091 & 0.082 & 0.073 & 0.064 & 0.056 & 0.047 & 0.038 & 0.030 & 0.022 \\
\hline \# Skin Layers & $n / a$ & 7.00 & 10.50 & 11.50 & 11.00 & 7.50 & 7.00 & 6.00 & 5.50 & 5.00 & 3.75 & 3.80 & 3.60 \\
\hline Skin Thick, m & 0.011 & 0.007 & 0.011 & 0.012 & 0.012 & 0.008 & 0.007 & 0.006 & 0.006 & 0.005 & 0.004 & 0.004 & 0.004 \\
\hline Skin X-Area, $m^{-}=2$ & 0.0154 & 0.0128 & 0.0232 & 0.0243 & 0.0222 & 0.0143 & 0.0124 & 0.0097 & 0.0080 & 0.0064 & 0.0041 & 0.0034 & 0.0025 \\
\hline $1 \times x$-Yors, $m^{-4} 4 \times 10.6$ & 752.95 & 972.90 & 2567.78 & 2466.36 & 2032.59 & 1173.60 & 875.43 & 577.20 & 385.67 & 239.53 & 113.24 & 63.72 & 28.25 \\
\hline lyy-Flap, $m^{\wedge} 4 \times 10.6$ & 376.47 & 245.69 & 193.47 & 149.79 & 110.25 & 59.84 & 40.79 & 24.96 & 15.40 & 8.76 & 3.78 & 1.87 & 0.74 \\
\hline 12x-Edpo, $m^{-4} 4 \times 10.6$ & 376.47 & 727.21 & 2374.31 & 2316.57 & 1922.34 & 1113.76 & 834.64 & 552.23 & 370.27 & 230.78 & 109.47 & 61.85 & 27.51 \\
\hline E. GPa & 10.44 & 38.66 & 55.63 & 21.84 & 18.04 & 24.94 & 30.04 & 39.78 & 43.43 & 34.40 & 16.49 & 33.37 & 84.63 \\
\hline E.psix $\times 1$ & 15.15 & 56.08 & 80.68 & 31.68 & 26.16 & 36.17 & 43.57 & 57.69 & 62.99 & 49.90 & 23.92 & 48.40 & 122.75 \\
\hline G. GPa & 12.00 & 12.00 & 12.00 & 12.00 & 12.00 & 12.00 & 12.00 & 12.00 & 12.00 & 12.00 & 12.00 & 12.00 & 12.00 \\
\hline Twist, deg & 29.85 & 26.28 & 20.00 & 14.81 & 10.61 & 7.29 & 4.74 & 2.87 & 1.57 & 0.74 & 0.27 & 0.06 & 0.00 \\
\hline 90.Twist & 60.15 & 63.72 & 70.00 & 75.19 & 79.39 & B2.71 & 85.26 & 87.13 & 88.43 & 89.26 & 89.73 & 89.94 & 90.00 \\
\hline Twist, rad & 0.52 & 0.46 & 0.35 & 0.26 & 0.19 & 0.13 & 0.08 & 0.05 & 0.03 & 0.01 & 0.00 & 0.00 & 0.00 \\
\hline Beam Length, m & 0.362 & 0.732 & 0.610 & 0.610 & 0.610 & 0.610 & 0.610 & 0.610 & 0.610 & 0.610 & 0.610 & 0.610 & 0.610 \\
\hline
\end{tabular}




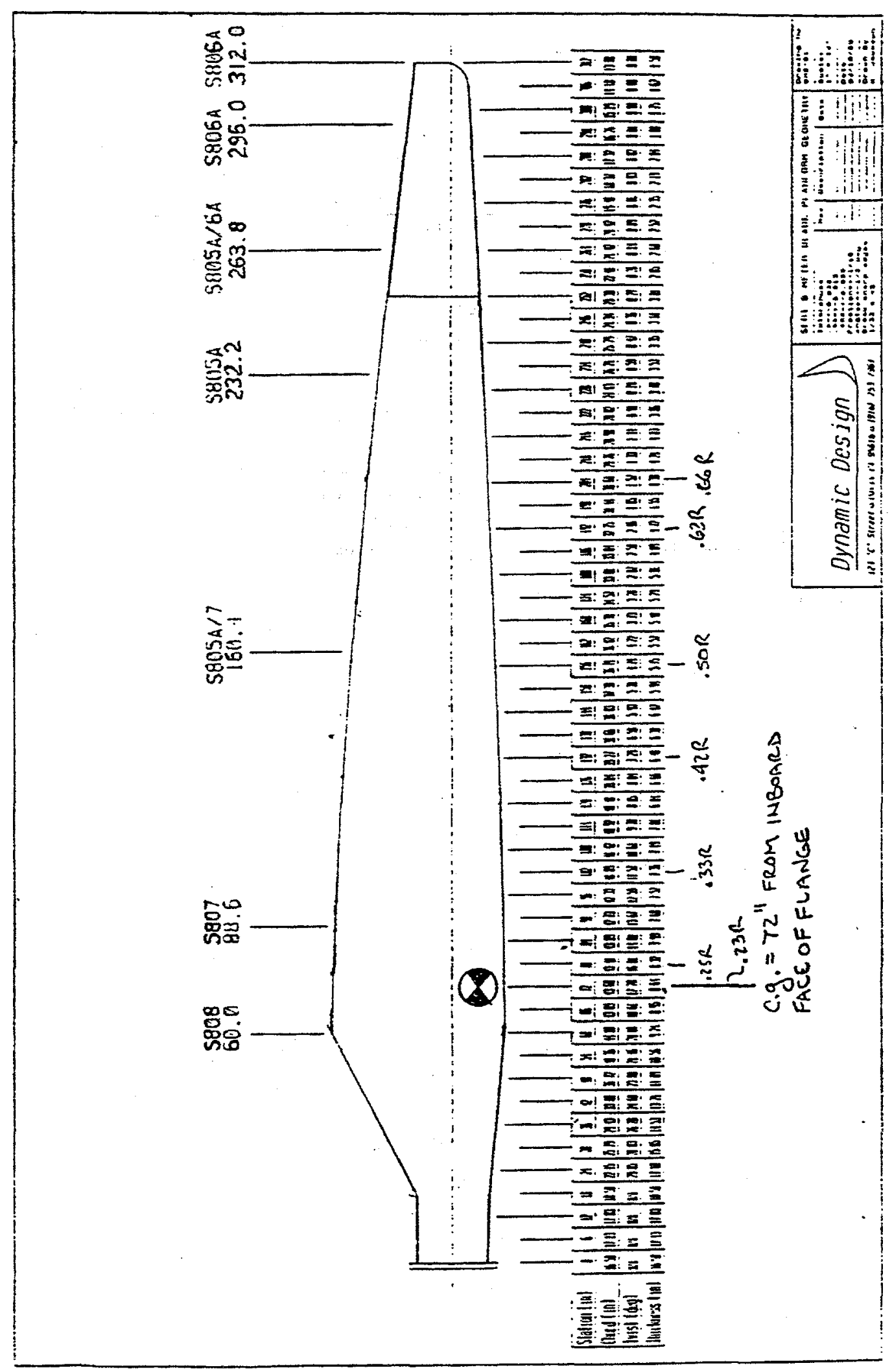

Figure 1.1 SERI-8 General Dimensions [3] 


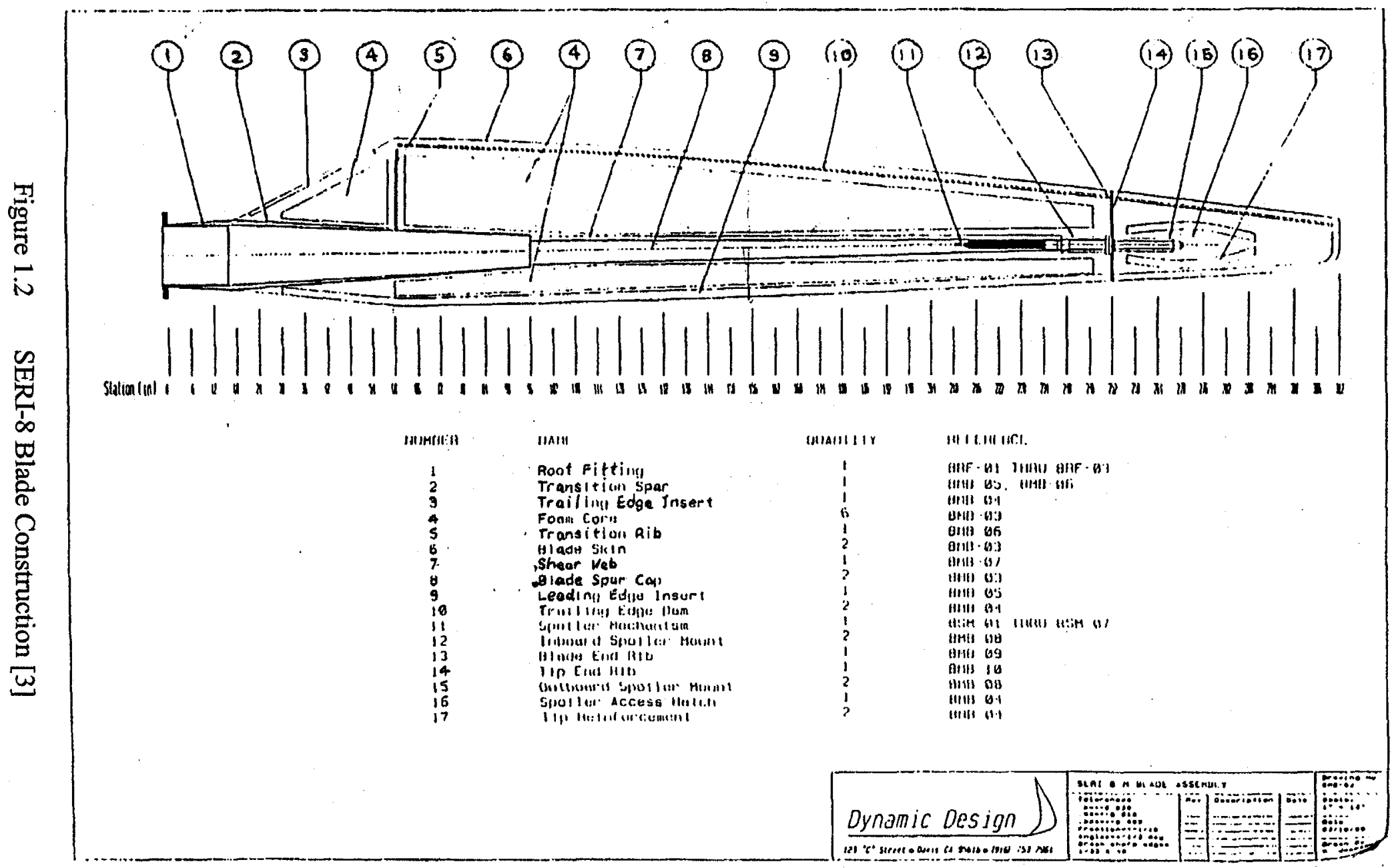




\section{Chapter 2}

\section{SERI-8 Blade Baseline Model}

The 3D-Beam [5] code was used to create the SERI-8 blade baseline finite element model. This code was also used to study enhanced models: a model with glass fibers being incrementally replaced by carbon fibers and one in which carbon fibers are placed at an off-axis direction for bend-induced-twist design.

In this chapter, we highlight our model's constraints and assumptions, and compare its predictions with data given in Keller and Smith [2], Jackson [3], and Klingenstein [4].

\subsection{Modeling Constraints and Assumptions}

The modeling constraints and assumptions are as follows:

a. Because data on lamination, such as schedule and material properties, is incomplete in Keller and Smith [2] and Jackson [3], we made a reasonable guess about both. As indicated in Jackson [3], the materials used were MAT, TRIAX and unidirectional-roving fibers; the material properties of these materials were not given in Jackson [3]. We used the material properties given by TPI [6], which is blade manufacturer. The material properties of three essential materials: MAT, TRIAX and unidirectional fiber, are shown in Table 2.1. We estimated the laminate schedule for the blade skin by matching the geometry and structural properties given in the works cited here.

b. The original design of the SERI-8 blade had foam core placed at various locations along the skin (see Figure 1.2) to increase local EI properties and to increase buckling strength; however, the foam core has negligible effect on overall EI properties and the baseline model does not include it. 
c. The original blade design also had a 96-inch long filament wound transition spar to which a 142-inch shear web was then attached. The skins of the shear webs consisted of 6-ply $\pm 45^{\circ}$ E-glass material. For the baseline blade model, a spar is assumed to be placed at the blade axis from station 12 to the end of the blade; the skin of the spar is assumed to have four layers of TRIAX material (see Table 2.1 also).

d. The original blade design had two ribs, located at stations 60 and 252, which are a transition rib and a blade/tip end rib, respectively. They were not modeled because of the 3D_Beam's limitations. In addition, the baseline model assumes that the blade structure is continuous; however, the actual blade construction was made up of two components: the main blade and the spoiler. The discontinuity occurred at station 252 .

e. The blade model is divided into twelve equal-span 24-inch components; the same division as in Keller and Smith [2]. The cross-section shape and chordwise length of each component are assumed to be the same at the midsection of that component.

\subsection{Modeling Results and Comparisons}

Comparisons between the 3D_Beam prediction and the reference data were made in three general areas: geometric properties, structural properties, and results of static tests. The geometric properties being studied are skin cross-section area and area moment of inertia $\left(I_{x x}, I_{y y} \& I_{z z}\right)$; all these properties do not require material information. The structural properties being studied are $\mathrm{EI}_{\mathrm{yy}}$ (flapping) and mass distribution along the blade span. Estimations of these properties require both material and geometric properties.

The estimated geometric properties -- skin cross-section area, $\mathrm{I}_{\mathrm{yy}}, \mathrm{I}_{\mathrm{zz}}$ and $\mathrm{I}_{\mathrm{xx}}$-- are shown in Figures 2.1 to 2.4 respectively. The estimated skin cross-section area and $\mathrm{I}_{\mathrm{yy}}$ agree very well with the results given in Keller and Smith [2] and Jackson [3]; however, the estimated $I_{x x}$ and $I_{z z}$ are higher than the results reported there.

The estimated structural properties -- $\mathrm{EI}_{\mathrm{yy}}$ and weight distribution -- are shown in Figures 2.5 and 2.6 respectively. The major differences between estimated and reported 
results are near the root and at station 60 , where there was a rib that was not modeled by the 3D_Beam code and may be the reason the estimated $\mathrm{EI}_{\mathrm{yy}}$ is lower than the reported value. It is also unclear whether the reported structural properties considered the effect of the steel root fitting. Inclusion of a steel root fitting in the estimate increases both weight and $\mathrm{EI}_{\mathrm{yy}}$ near the root area. The weight comparison near the root improves after the effect of a root fitting is included; however, there is a huge $\mathrm{EI}_{\mathrm{yy}}$ difference near the root.

After having reasonably matched geometric and structural properties, the estimated static deflection and that reported in Klingenstein [4] were compared. The load was applied at the tip (station 312), and the root was clamped. The comparisons also included the estimated results without root fitting, though it is believed the test was done on a complete SERI-8 blade (with root fitting). The estimated results (with root fitting) agree well with the reported test results (see Figure 2.7).

\subsection{Laminate Schedule for Baseline SERI-8 Model}

The final laminate schedule for the baseline SERI-8 model is shown on Table 2.2. The composition of the lay-up is about $80 \%$ unidirectional-roving fibers, $17 \%$ TRIAX, and $3 \%$ MAT. 
Table 2.1 Material Properties Data [6]

\begin{tabular}{|c|c|c|c|}
\hline \multicolumn{2}{|c|}{$\mathrm{E}_{1}=$ Longitudinal Modulus (msi) } & \multicolumn{2}{|c|}{$\mathrm{X}_{\mathrm{T}}=$ Axial Failure Stress - Tension $(\mathrm{ksi})$} \\
\hline \multicolumn{2}{|c|}{$\mathrm{E}_{2}=$ Transverse Modulus (msi) } & \multicolumn{2}{|c|}{$\mathrm{X}_{\mathrm{C}}=$ Axial Failure Stress - Compression (ksi) } \\
\hline \multicolumn{2}{|c|}{$\mathrm{G}_{12}=$ In-plane Shear Modulus (msi) } & \multicolumn{2}{|c|}{$\mathrm{Y}_{\mathrm{T}}=$ Transverse Failure Stress - Tension (ksi) } \\
\hline \multicolumn{2}{|c|}{$v_{12}=$ Poisson's Ratio } & \multicolumn{2}{|c|}{$\mathrm{Y}_{\mathrm{C}}=$ Transverse Failure Stress - Compression $(\mathrm{ksi})$} \\
\hline \multicolumn{2}{|c|}{$\mathrm{t}=$ thickness $\left(10^{-3} \mathrm{in}\right)$} & \multicolumn{2}{|c|}{$\mathrm{S}=$ Shear Failure Stress (ksi) } \\
\hline Material & $\begin{array}{l}\text { DDB340 } \\
\text { (TRIAX) }\end{array}$ & $\begin{array}{c}\mathrm{C} 260 \\
\text { (Unidirectional) }\end{array}$ & MAT \\
\hline$E_{1}$ & 3.93 & 6.14 & 1.1 \\
\hline $\mathrm{E}_{2}$ & 1.64 & 1.41 & 1.1 \\
\hline $\mathrm{G}_{12}$ & 0.94 & 0.94 & 0.94 \\
\hline$v_{12}$ & 0.3 & 0.3 & 0.3 \\
\hline $\mathrm{X}_{\mathrm{T}}$ & 88.2 & 103 & 19 \\
\hline $\mathrm{X}_{\mathrm{C}}$ & 53.1 & 49.8 & 20 \\
\hline $\mathrm{Y}_{\mathrm{T}}$ & 13.6 & 2.3 & 19 \\
\hline $\mathrm{Y}_{\mathrm{C}}$ & 15 & 2.3 & 20 \\
\hline $\mathrm{S}$ & 15 & 3.6 & 13 \\
\hline $\mathrm{t}$ & 15 & 5 & 5 \\
\hline
\end{tabular}


Table 2.2 Laminate Lay-up for SERI-8 Baseline Model

\begin{tabular}{|c|c|c|c|c|}
\hline Station & Laminate Lay-up & $\begin{array}{c}\text { Volume } \\
\text { Fraction of } \\
\text { C260 Material }\end{array}$ & $\begin{array}{c}\text { Volume } \\
\text { Fraction of } \\
\text { TRIAX }\end{array}$ & $\begin{array}{l}\text { Volume } \\
\text { Fraction of } \\
\text { MAT }\end{array}$ \\
\hline $0-24$ & $\begin{array}{l}2 \times \text { XAT; } \\
4 \text { x TRIAX; } \\
75 \text { x C260 }\left(90^{\circ}\right)\end{array}$ & $84.3 \%$ & $13.5 \%$ & $2.2 \%$ \\
\hline $24-48$ & $\begin{array}{l}2 \times \text { MAT; } \\
4 \times \text { TRIAX; } \\
40 \times \text { C } 260\left(0^{\circ}\right)\end{array}$ & $74.1 \%$ & $22.2 \%$ & $3.7 \%$ \\
\hline $48-72$ & $\begin{array}{l}2 \times \text { MAT; } \\
4 \times \text { TRIAX; } \\
60 \times \text { C } 260\left(0^{\circ}\right) \\
\end{array}$ & $81.1 \%$ & $16.2 \%$ & $2.7 \%$ \\
\hline $72-96$ & $\begin{array}{l}2 \times \text { MAT; } \\
3 \times \text { TRIAX; } \\
80 \times \text { C } 260\left(0^{\circ}\right)\end{array}$ & $87.9 \%$ & $9.9 \%$ & $2.2 \%$ \\
\hline $96-120$ & $\begin{array}{l}2 \text { x MAT; } \\
3 \text { x TRIAX; } \\
70 \times \text { C } 260\left(0^{\circ}\right)\end{array}$ & $86.4 \%$ & $11.1 \%$ & $2.5 \%$ \\
\hline $120-168$ & $\begin{array}{l}2 \times \text { MAT; } \\
2 \times \text { TRIAX; } \\
55 \times \text { C } 260\left(0^{\circ}\right)\end{array}$ & $87.3 \%$ & $9.5 \%$ & $3.2 \%$ \\
\hline $168-192$ & $\begin{array}{l}2 \times \text { MAT; } \\
2 \times \text { TRIAX; } \\
42 \times \text { C } 260\left(0^{\circ}\right) \\
\end{array}$ & $84.0 \%$ & $12.0 \%$ & $4.0 \%$ \\
\hline $192-240$ & $\begin{array}{l}2 \times \text { MAT; } \\
2 \times \text { TRIAX; } \\
30 \times \mathrm{C} 260\left(0^{\circ}\right)\end{array}$ & $78.9 \%$ & $15.8 \%$ & $5.3 \%$ \\
\hline $240-288$ & $\begin{array}{l}2 \times \text { MAT; } \\
2 \times \text { TRIAX; } \\
25 \times \text { C } 260\left(0^{\circ}\right)\end{array}$ & $75.8 \%$ & $18.2 \%$ & $6.1 \%$ \\
\hline $288-312$ & $\begin{array}{l}2 \times \text { MAT; } \\
6 \times \text { TRIAX }\end{array}$ & $0.0 \%$ & $90.0 \%$ & $10.0 \%$ \\
\hline Spar & $4 \times$ TRIAX & $0.0 \%$ & $100.0 \%$ & $0.0 \%$ \\
\hline
\end{tabular}

*: The first number is the number of layers (i.e. $2 \times$ MAT means 2 layers of MAT material). 


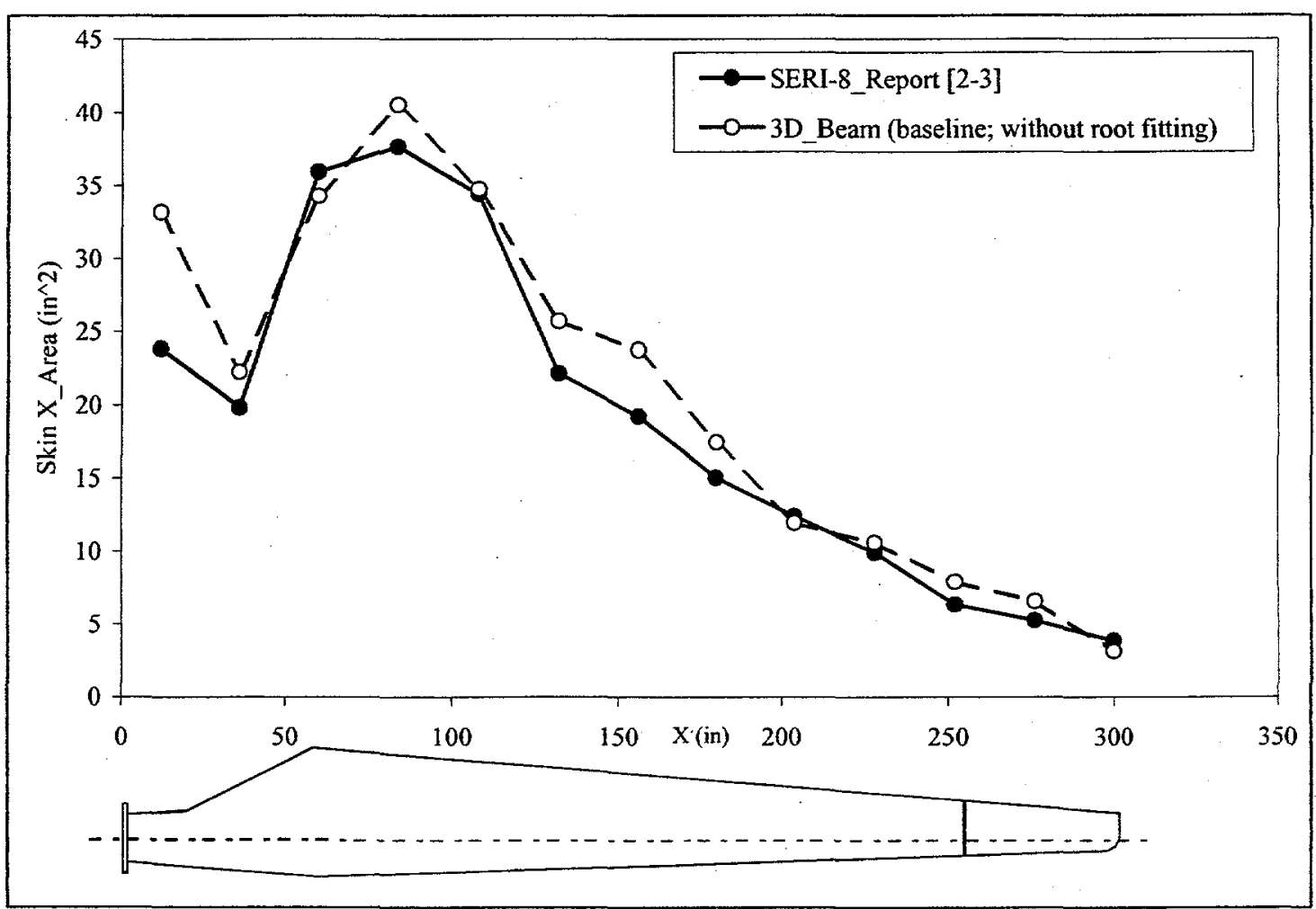

Figure 2.1 Skin Cross-section Area Distribution along a SERI-8 Blade

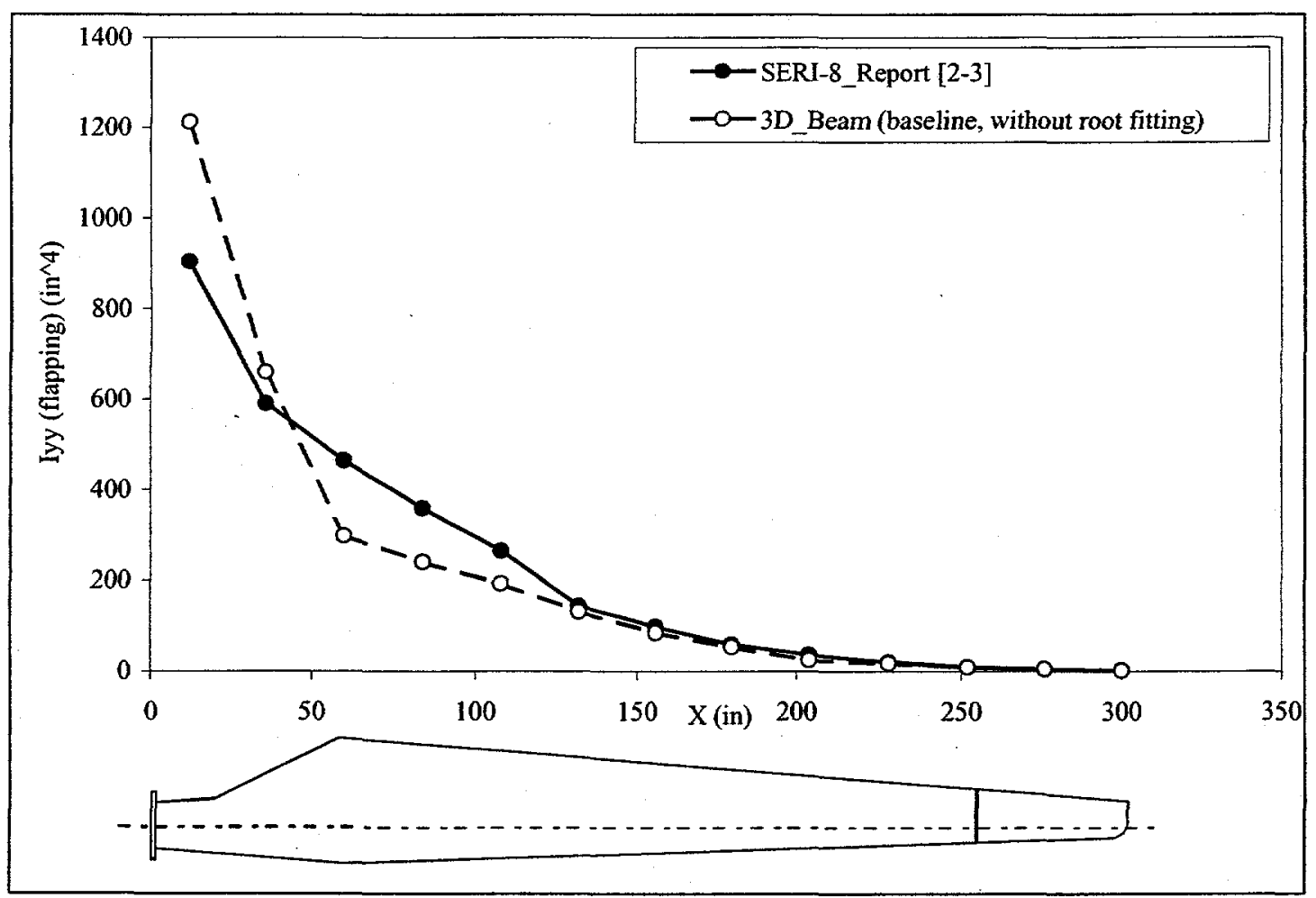

Figure 2.2 Iyy Distribution along a SERI-8 Blade 


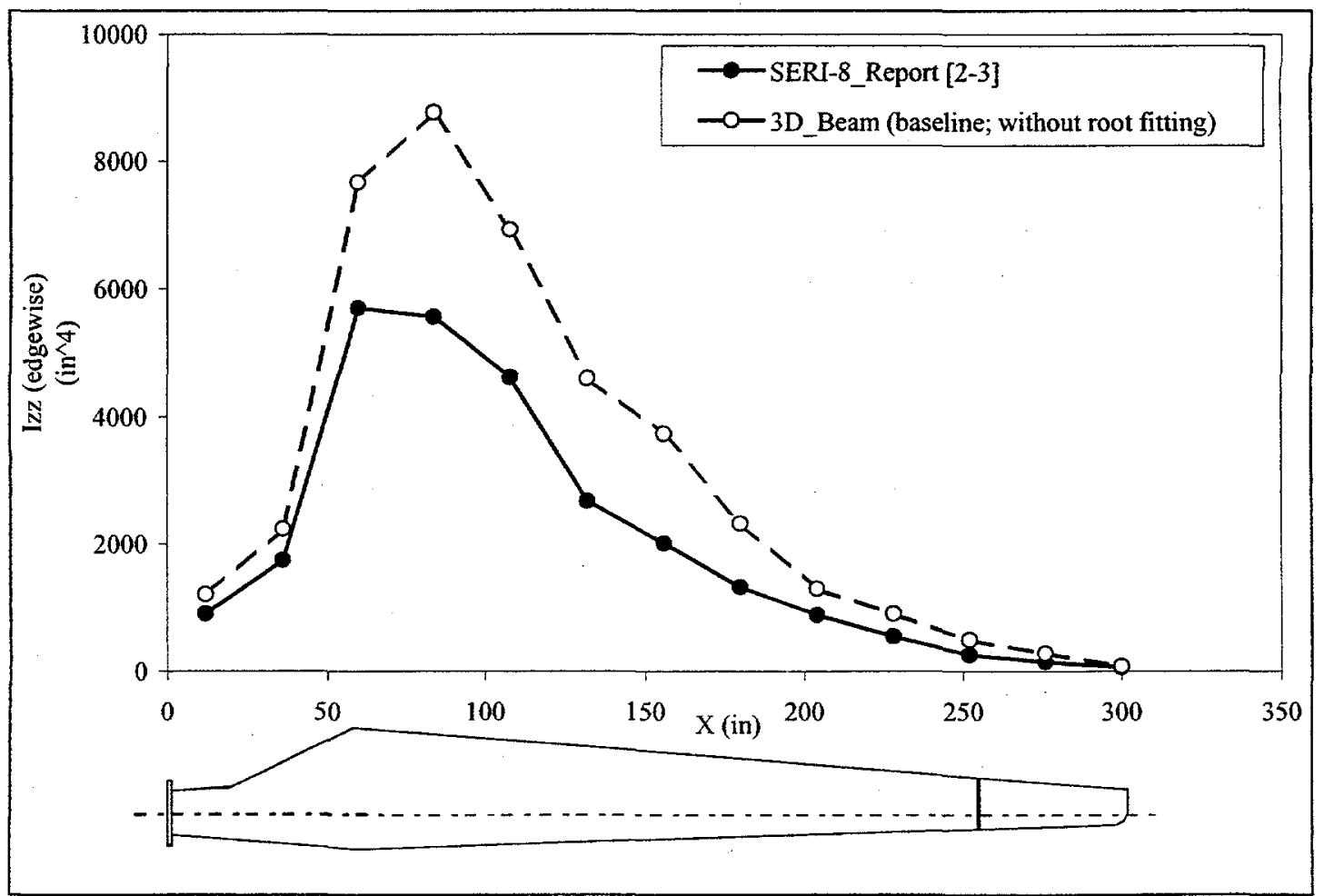

Figure 2.3 $\quad I_{z z}$ Distribution along a SERI-8 Blade

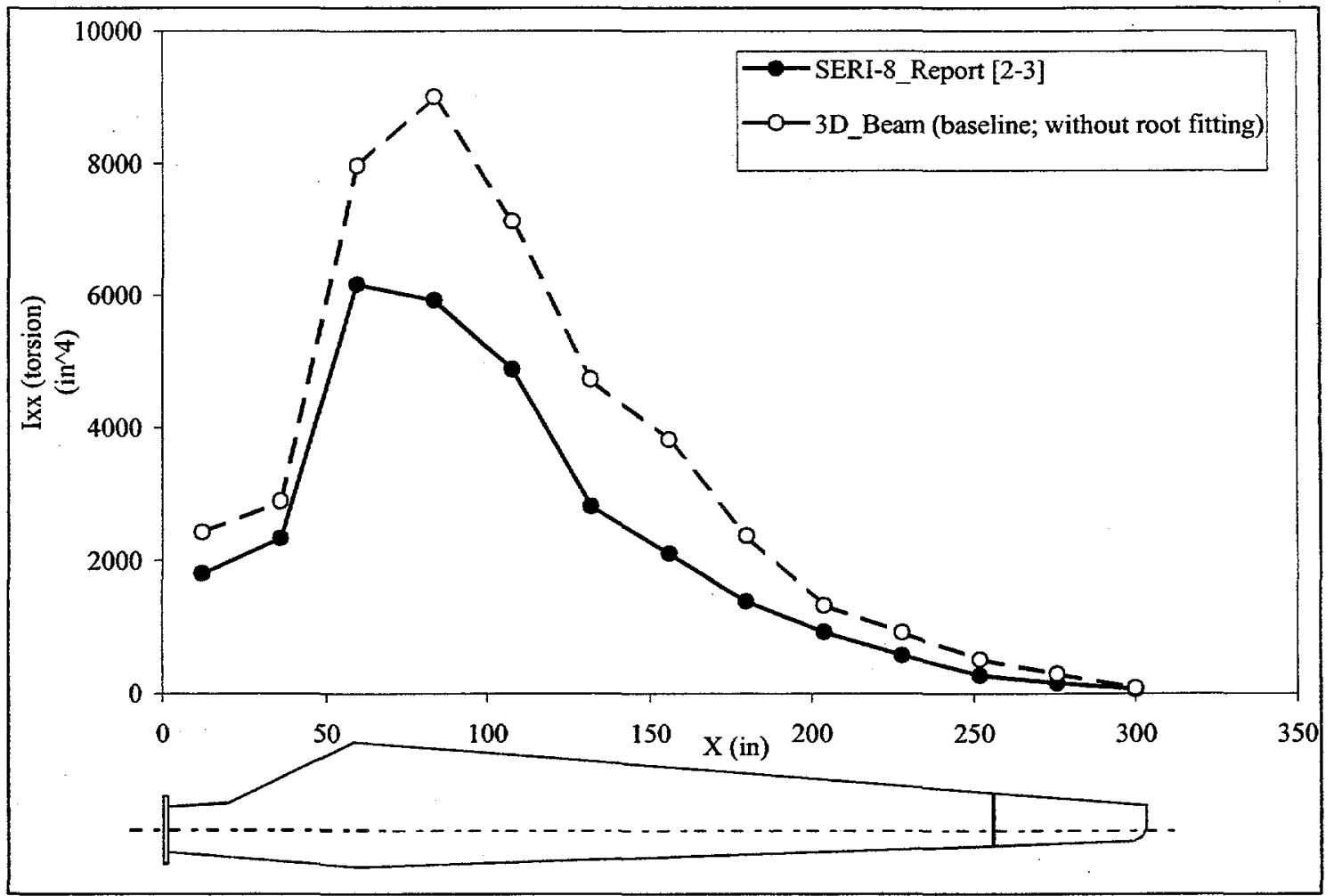

Figure 2.4 $I_{x x}$ Distribution along a SERI-8 Blade 


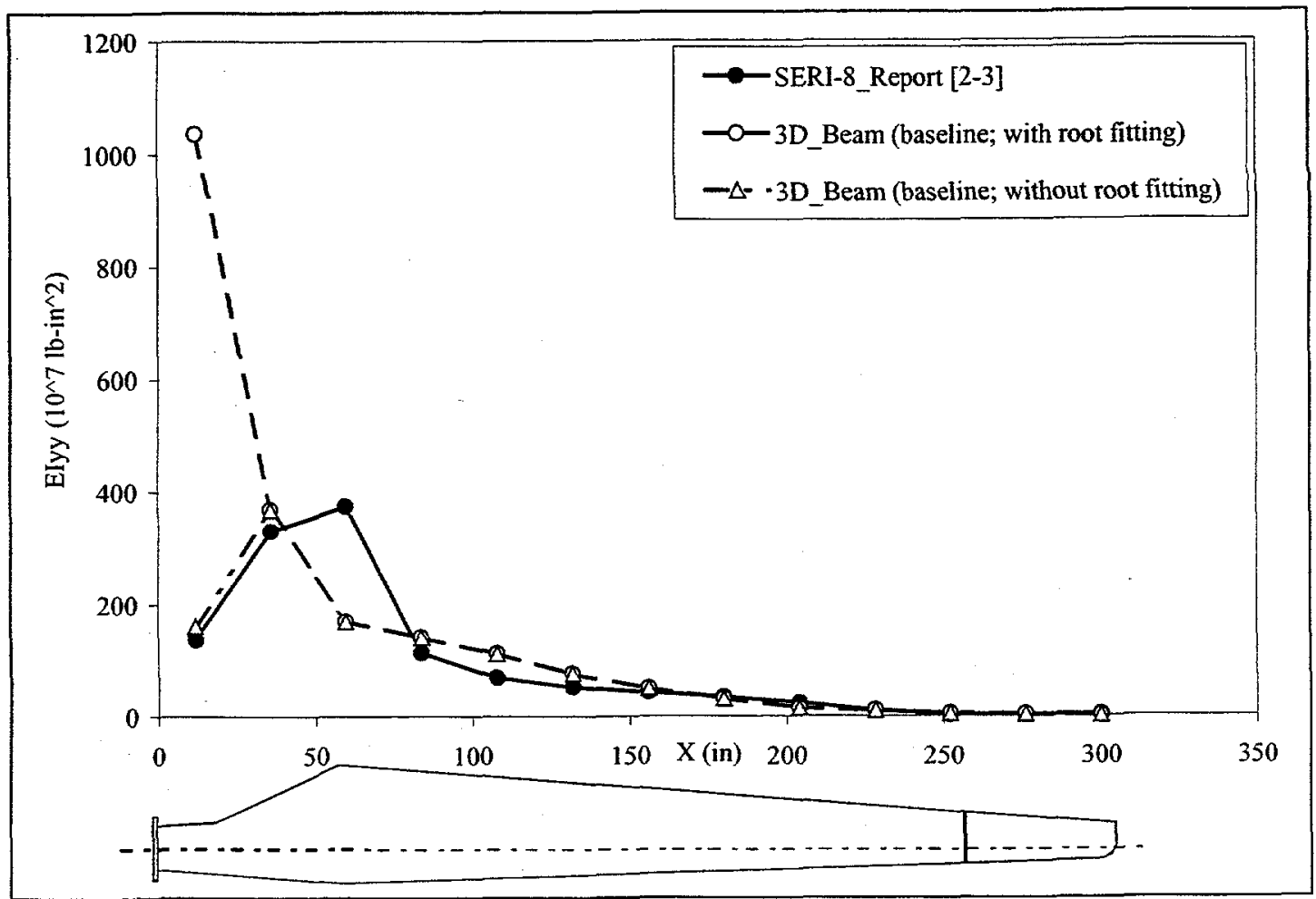

Figure 2.5 $\mathrm{EI}_{\mathrm{yy}}$ Distribution along a SERI-8 Blade

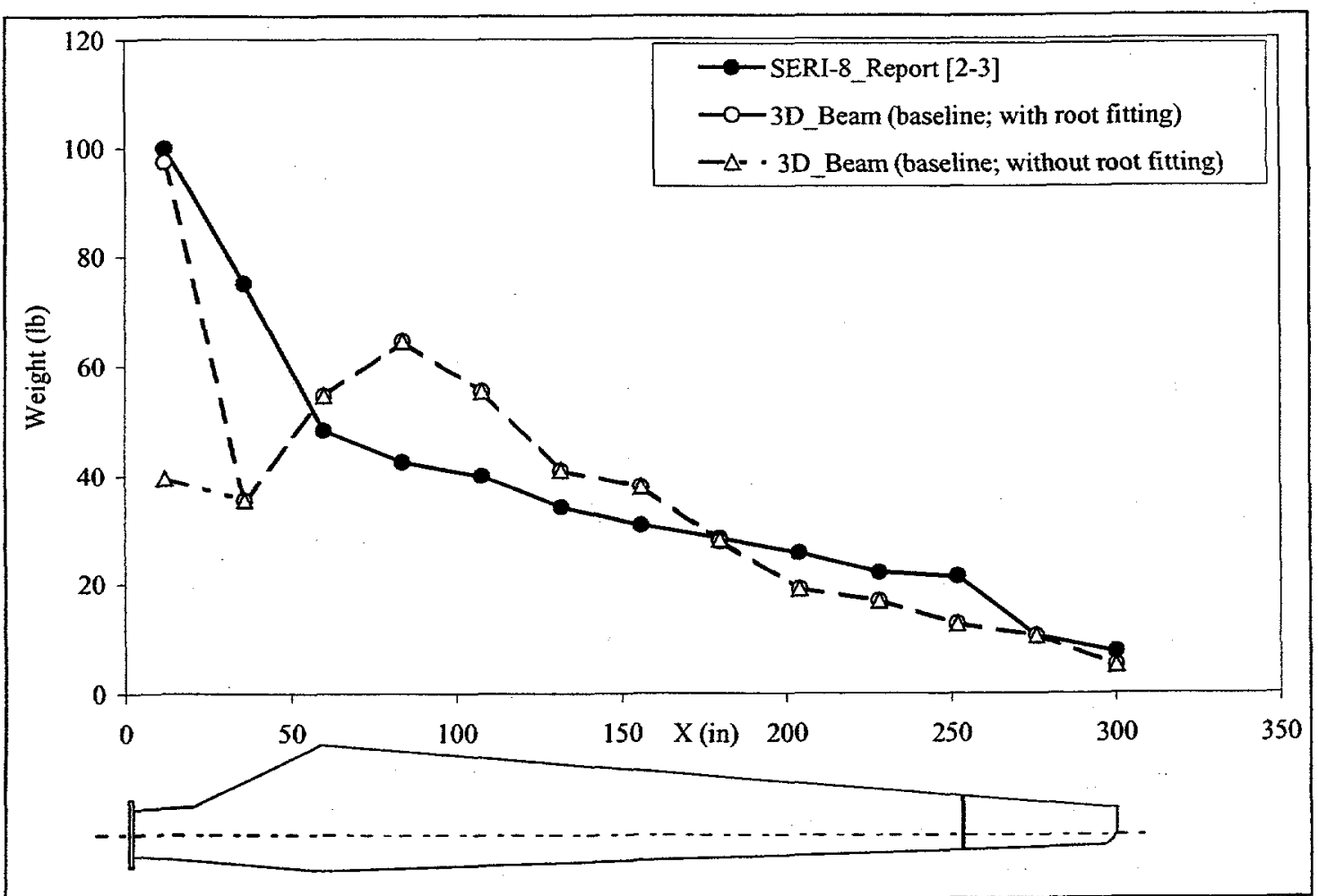

Figure 2.6 Weight Distribution along a SERI-8 Blade 


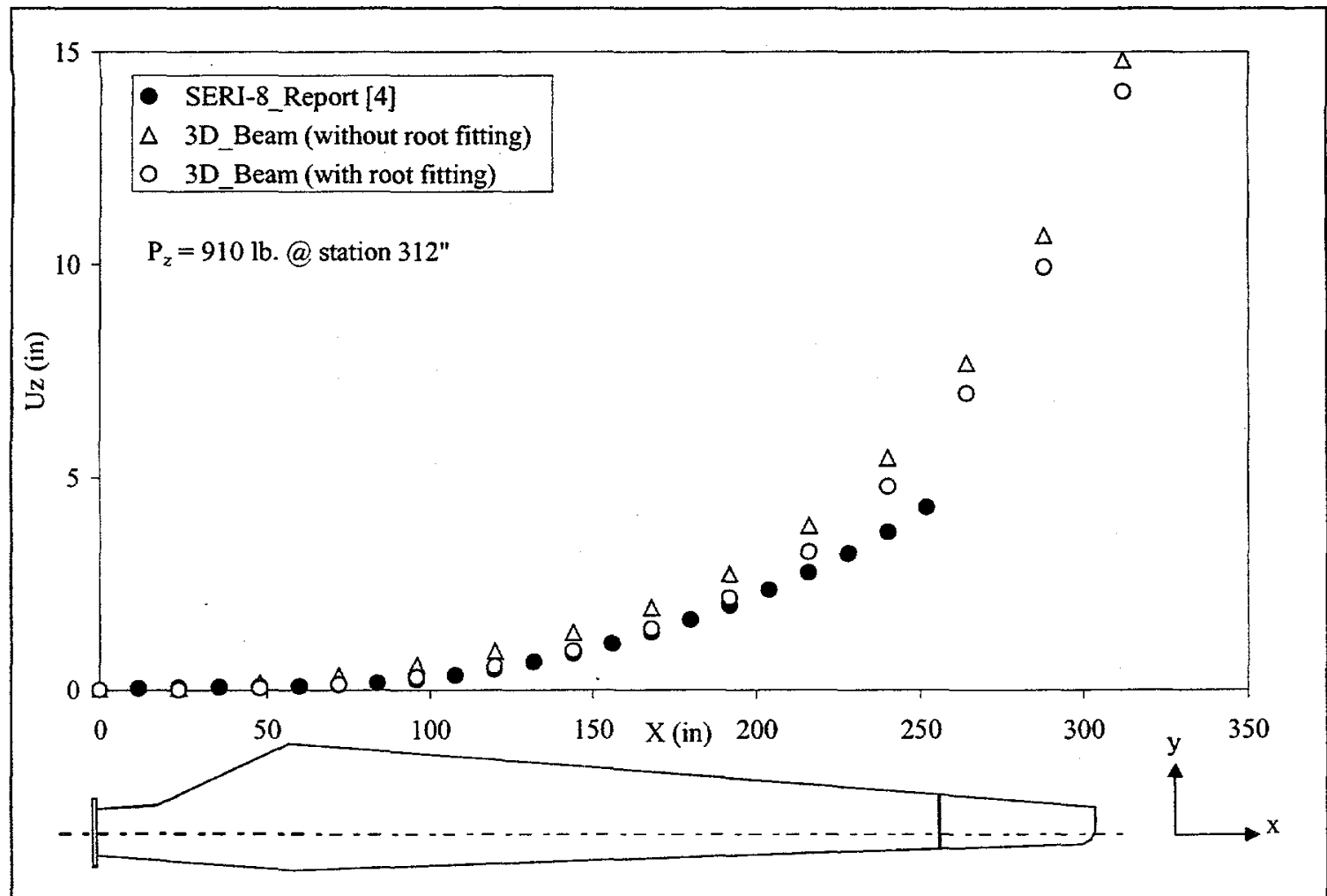

Figure 2.7 Vertical Deflection along the Blade for a Point Load of 910 lbs. applied at Station 312. 


\section{Chapter 3}

\section{SERI-8 Blade Enhanced Models}

The baseline model, which is discussed in the previous chapter, was modified to study the effect of using carbon fibers with and without bend-twist-coupled design. The evaluation parameters not only included geometric and structural properties, but also a cost model that is discussed in a subsequent chapter.

The laminate lay-up for the baseline model is composed of roughly $80 \%$ unidirectional glass fibers, $17 \%$ TRIAX and 3\% MAT (see Table 2.2). The criterion for transforming the baseline model to an enhanced model (with and without bend-twistcoupled design) is to maintain the same flapping stiffness (EI $\mathrm{yy}_{\mathrm{y}}$, see Figure 3.1). To achieve the design criterion for the enhanced models, it is more efficient to replace unidirectional glass fibers with unidirectional carbon fibers and leave the TRIAX and MAT materials untouched.

\subsection{Generation of Enhanced Models}

The procedures to generate an enhanced model (with and without bend-twistcoupled design) are as follows:

a. Only unidirectional glass fibers are replaced.

b. The blade is divided into 13 equal lengths of 24 -inch blade elements. The laminate lay-up for the first (station 0 - 24) and last (station 288 - 312) blade elements remains unchanged. The last blade element only has MAT and TRIAX materials. The first blade element is a part of the transition spar in the real blade design.

c. An incremental volume fraction (based on the volume of individual blade elements) of unidirectional glass fibers of each blade element is removed from the baseline model. 
d. An equivalent amount of volume of unidirectional carbon fibers (material properties are given in Table 3.1) is substituted for the removed glass fibers. The volume of carbon fibers required for each blade element is determined by maintaining the same $\mathrm{EI}_{\mathrm{yy}}$ for that blade element.

e. In bend-twist-coupled design, all unidirectional carbon fibers are orientated from 0 degrees to 20 degrees to achieve higher bend-twist coupling. Additional carbon fibers are added to maintain the same $\mathrm{EI}_{\mathrm{yy}}$.

\subsection{Loading Conditions for Failure Analysis}

In addition, to evaluate the geometric and structural properties, it is also important to know the enhanced model is able to withstand extreme wind conditions. The extreme wind design load generally used for wind turbine blade design is 70 meters/second wind speed, with $\mathrm{C}_{\mathrm{d}}=1.7$.

As the current 3D_Beam model cannot handle a distributed load (such as pressure load), we must transform the distributed load to nodal forces using an energy method. Figure 3.2 shows the nodal force distribution along the blade after the transformation.

\subsection{Results \& Discussions}

Tables 3.2 - 3.11 show the laminate lay-up for various blade configurations, which incrementally replace unidirectional glass fibers with unidirectional carbon fibers. Configurations shown in Tables 3.2 - 3.6 are for blade models designed without bendtwist-coupling. Configurations shown in Tables $3.7-3.11$ are for blade models designed for bend-twist-coupling.

The main advantage of replacing glass fibers with carbon fibers is reduction in blade weight, as shown in Figure 3.3 - 3.4. A lighter blade design could have many advantages, including ease of handling and transportation, as well as lowering tower head mass. The skin cross-section area (Figure 3.5) and area moments of inertia (Figures 3.6 3.8) are also reduced. The same reductions are also seen in blade configurations designed for bend-twist coupling. Additional parameters being evaluated in bend-twist-coupled 
configurations were the cross-coupling parameter $(\alpha)$ [7], bend-induced twist distribution and vertical deflection $\left(U_{z}\right)$ under the design wind condition.

Figure 3.9 shows the cross-coupling parameter $(\alpha)$ distribution for various bendtwist-coupled configurations. The cross-coupling parameter is seen to be nearly constant for a bend-twist-coupled configuration, although the volumes of carbon fibers for each blade element change along the blade (see Tables $3.7-3.11$ ). This observation reinforces one of the findings in a previous project [7] -- the cross-coupling parameter depends on the volume fraction of the anisotropy layers and does not depend on the actual volume of the anisotropy layers.

A bend-twist-coupled blade is more flexible than a normal blade without bendtwist-coupled design, although both blades have the same flapping stiffness property $\left(E I_{y y}\right)$. Consequently, a bend-twist-coupled blade will have a higher deflection than a normal blade. Figure 3.10 shows the vertical deflection distribution along SERI- 8 blades for various bend-twist-coupled configurations subjected to a wind load of 70 meters/second. The bend-induced twist distribution for the same wind condition for various bend-twist-coupled configurations is shown on Figure 3.11.

One bend-twist-coupled blade configuration was chosen for failure analysis and the selection criterion is based primarily on the highest bend-induced twist angle. The selected configuration was the blade model having $100 \%$ unidirectional glass fibers replacement; in addition, failure analysis was carried out for the baseline configuration for comparison's sake.

Since each blade element (total of 13 blade elements) has different geometry and structural properties, the failure may not occur at the root area. Thus, it was necessary to carry out a failure analysis for each blade element for the baseline configuration and the selected bend-twist-coupled (twist-to-feather) configuration shown in Figures 3.12 and 3.13. Failure occurs when the failure index is more than one [5]. Each blade element is modeled by 28 brick-elements for the skin and 1 brick-element for the spar. Except blade element number ' 1 ' (between station 0 and 24), the brick-element number for the spar (the spar begins from station 24) is designated as number ' 29 '. Both figures indicate that the likely failure location for both configurations (baseline and the selected bend-twistcoupled configurations) is near the root area. In addition, the factor of safety, which is in 
inverse proportion to the failure index, is about two for the two configurations under the same severe wind condition.

Figures 3.14 - 3.26 show the estimated failure index (top diagram), and the shape and brick-element numbering (bottom diagram) in each blade element for the baseline configuration as well as both twist-to-stall and twist-to-feather coupled designs. The highest overall failure index (most likely to fail) occurs in the baseline design at element 9. The failure index is 0.50 resulting in a design factor of safety of 2.0 . The maximum failure index for the twist-to-stall design is 0.32 at element 2 , and for the twist-to-feather design is 0.41 at element 6 . In every case except one, the twist-to-stall maximum failure index is lower than the baseline; the exception is at element 2 (see Figure 3.15). The twist to feather failure index is higher than the baseline for elements 2-7 (see Figures 3.15 3.20 ), and lower for elements 8-12 (see Figures $3.21-3.25$ ). The failure indices for most of the "Brick" elements all along the blade are higher for the bend-twist-coupled blades than that of the baseline configuration, although well below the local maximums.

The bend-twist-coupled designs also shift the location of maximum failure index at each section. The highest index occurs at the leading edge brick-element for the baseline and twist-to-feather configurations, and is usually at the middle brick-element for the twist-to-stall configuration.

The failure prediction assumes that the joint between the two halves of the bendtwist blade is seamless. In fact, there is a discontinuity of the 20-degree fibers at the seam. The failure index similarly treats all "Brick" elements as equally strong and does not recognize the weak connection at the joint. To strengthen the joint at the seam, it is suggested that a staggered overlap joining method [7] or some other joint reinforcement technique be adopted. 
Table 3.1 Material Properties Data for CFRP AS/H3501

\begin{tabular}{|c|c|}
\hline $\mathrm{E}_{\mathrm{x}}=$ Longitudinal Modulus (msi) & $\mathrm{X}_{\mathrm{T}}=$ Axial Failure Stress - Tension $(\mathrm{ksi})$ \\
\hline$E_{y}=$ Transverse Modulus (msi) & $\mathrm{X}_{\mathrm{C}}=$ Axial Failure Stress - Compression (ksi) \\
\hline$G_{x y}=$ In-plane Shear Modulus (msi) & $\mathrm{Y}_{\mathrm{T}}=$ Transverse Failure Stress - Tension $(\mathrm{ksi})$ \\
\hline$v_{x}=$ Poisson's Ratio & $\mathrm{Y}_{\mathrm{C}}=$ Transverse Failure Stress - Compression $(\mathrm{ksi})$ \\
\hline $\mathrm{t}=$ thickness $\left(10^{-3} \mathrm{in}\right)$ & $\mathrm{S}=$ Shear Failure Stress (ksi) \\
\hline Material & CFRP AS/H3501 \\
\hline $\mathrm{E}_{\mathrm{x}}$ & 20.0 \\
\hline $\mathrm{E}_{\mathrm{y}}$ & 1.3 \\
\hline $\mathrm{G}_{\mathrm{xy}}$ & 1.03 \\
\hline$v_{\mathrm{x}}$ & 0.3 \\
\hline$X_{T}$ & 209.8 \\
\hline $\mathrm{X}_{\mathrm{C}}$ & 209.8 \\
\hline $\mathrm{Y}_{\mathrm{T}}$ & 7.5 \\
\hline $\mathrm{Y}_{\mathrm{C}}$ & 29.9 \\
\hline$S$ & 13.5 \\
\hline $\mathrm{t}$ & 4.925 \\
\hline
\end{tabular}


Table 3.2 Laminate Lay-up for SERI-8 Enhanced Model (without bend-twistcoupling) with $20 \%$ Unidirectional Glass Replacement.

\begin{tabular}{|c|c|c|c|c|c|}
\hline Station & Laminate Lay-up ${ }^{*}$ & $\begin{array}{l}\text { Volume } \\
\text { Fraction of } \\
\text { AS/H3501 }\end{array}$ & $\begin{array}{c}\text { Volume } \\
\text { Fraction of } \\
\text { C260 Material }\end{array}$ & $\begin{array}{l}\text { Volume } \\
\text { Fraction of } \\
\text { TRIAX }\end{array}$ & $\begin{array}{l}\text { Volume } \\
\text { Fraction of } \\
\text { MAT }\end{array}$ \\
\hline $0-24$ & $\begin{array}{l}2 \times \text { MAT; } 4 \times \text { TRIAX; } \\
75 \times \text { C } 260\left(90^{\circ}\right)\end{array}$ & $0.0 \%$ & $84.3 \%$ & $13.5 \%$ & $2.2 \%$ \\
\hline $24-48$ & $\begin{array}{l}2 \times \text { MAT; } 4 \times \text { TRIAX; } \\
32 \times \text { C } 260\left(0^{\circ}\right) ; \\
2 \times \text { AS/H } 3501\left(0^{\circ}\right)\end{array}$ & $4.2 \%$ & $66.7 \%$ & $25.0 \%$ & $4.2 \%$ \\
\hline $48-72$ & $\begin{array}{l}2 \times \text { MAT; } 4 \times \text { TRIAX; } \\
48 \times \text { C260 }\left(0^{\circ}\right) \\
3 \times \text { AS/H3501 }\left(0^{\circ}\right)\end{array}$ & $4.6 \%$ & $73.8 \%$ & $18.5 \%$ & $3.1 \%$ \\
\hline $72-96$ & $\begin{array}{l}2 \times \mathrm{MAT} ; 3 \times \mathrm{TRIAX} ; \\
64 \times \mathrm{C} 260\left(0^{\circ}\right) ; \\
4 \times \mathrm{AS} / \mathrm{H} 3501\left(0^{\circ}\right)\end{array}$ & $5.1 \%$ & $81.0 \%$ & $11.4 \%$ & $2.5 \%$ \\
\hline $96-120$ & $\begin{array}{l}2 \times \text { MAT } ; 3 \times \text { TRIAX; } \\
56 \times \mathrm{C} 260\left(0^{\circ}\right) \\
3 \times \mathrm{AS} / \mathrm{H} 3501\left(0^{\circ}\right)\end{array}$ & $4.3 \%$ & $80.0 \%$ & $12.9 \%$ & $2.9 \%$ \\
\hline $120-144$ & $\begin{array}{l}2 \times \text { MAT } ; 2 \times \text { TRIAX; } \\
44 \times \text { C } 260\left(0^{\circ}\right) ; \\
3 \times \text { AS } / \mathrm{H} 3501\left(0^{\circ}\right)\end{array}$ & $5.5 \%$ & $80.0 \%$ & $10.9 \%$ & $3.6 \%$ \\
\hline $144-168$ & $\begin{array}{l}2 \times \text { MAT; } 2 \times \text { TRIAX; } \\
44 \times \text { C260 }\left(0^{\circ}\right) ; \\
3 \times \text { AS/H } 3501\left(0^{\circ}\right)\end{array}$ & $5.5 \%$ & $80.0 \%$ & $10.9 \%$ & $3.6 \%$ \\
\hline $168-192$ & $\begin{array}{l}2 \times \text { MAT; } 2 \times \text { TRIAX; } \\
34 \times \text { C260 }\left(0^{\circ}\right) ; \\
2 \times \text { AS } / \mathrm{H} 3501\left(0^{\circ}\right)\end{array}$ & $4.5 \%$ & $77.3 \%$ & $13.6 \%$ & $4.5 \%$ \\
\hline $192-216$ & $\begin{array}{l}2 \times \text { MAT } ; 2 \times \text { TRIAX; } \\
24 \times \text { C } 260\left(0^{\circ}\right) ; \\
2 \times \text { AS/H } 3501\left(0^{\circ}\right)\end{array}$ & $5.9 \%$ & $70.6 \%$ & $17.6 \%$ & $5.9 \%$ \\
\hline $216-240$ & $\begin{array}{l}2 \times \text { MAT; } 2 \times \text { TRIAX; } \\
24 \times \text { C260 }\left(0^{\circ}\right) ; \\
2 \times \text { AS/H } 3501\left(0^{\circ}\right)\end{array}$ & $5.9 \%$ & $70.6 \%$ & $17.6 \%$ & $5.9 \%$ \\
\hline $240-264$ & $\begin{array}{l}2 \times \mathrm{MAT} ; 2 \times \mathrm{TRIAX} ; \\
20 \times \mathrm{C} 260\left(0^{\circ}\right) ; \\
1 \times \mathrm{AS} / \mathrm{H} 3501\left(0^{\circ}\right)\end{array}$ & $3.4 \%$ & $69.0 \%$ & $20.7 \%$ & $6.9 \%$ \\
\hline $264-288$ & $\begin{array}{l}2 \times \text { MAT; } 2 \times \text { TRIAX; } \\
20 \times \mathrm{C} 260\left(0^{\circ}\right) ; \\
1 \times \mathrm{AS} / \mathrm{H} 3501\left(0^{\circ}\right)\end{array}$ & $3.4 \%$ & $69.0 \%$ & $20.7 \%$ & $6.9 \%$ \\
\hline $288-312$ & $2 \mathrm{x}$ MAT; $6 \times$ TRIAX & $0.0 \%$ & $0.0 \%$ & $90.0 \%$ & $10.0 \%$ \\
\hline Spar & $4 \times$ TRIAX & $0.0 \%$ & $0.0 \%$ & $90.0 \%$ & $10.0 \%$ \\
\hline
\end{tabular}

*: The first number is the number of layers (i.e: $2 \times$ MAT means 2 layers of MAT material). 
Table 3.3 Laminate Lay-up for SERI-8 Enhanced Model (without bend-twistcoupling) with $40 \%$ Unidirectional Glass Replacement

\begin{tabular}{|c|c|c|c|c|c|}
\hline Station & Laminate Lay-up $^{*}$ & $\begin{array}{c}\text { Volume } \\
\text { Fraction of } \\
\text { AS/H3501 }\end{array}$ & $\begin{array}{c}\text { Volume } \\
\text { Fraction of } \\
\text { C260 Material } \\
\end{array}$ & $\begin{array}{c}\text { Volume } \\
\text { Fraction of } \\
\text { TRLAX }\end{array}$ & $\begin{array}{c}\text { Volume } \\
\text { Fraction of } \\
\text { MAT }\end{array}$ \\
\hline $0-24$ & $\begin{array}{l}2 \times \text { MAT; } 4 \times \text { TRIAX; } \\
75 \times \text { C } 260\left(90^{\circ}\right)\end{array}$ & $0.0 \%$ & $84.3 \%$ & $13.5 \%$ & $2.2 \%$ \\
\hline $24-48$ & $\begin{array}{l}2 \times \text { MAT; } 4 \times \text { TRIAX; } \\
24 \times \text { C } 260\left(0^{\circ}\right) ; \\
5 \times \text { AS/H3501 }\left(0^{\circ}\right)\end{array}$ & $11.6 \%$ & $55.8 \%$ & $27.9 \%$ & $4.7 \%$ \\
\hline $48-72$ & $\begin{array}{l}2 \times \text { MAT; } 4 \times \text { TRIAX; } \\
36 \times \text { C } 260\left(0^{\circ}\right) ; \\
5 \times \text { AS/H3501 }\left(0^{\circ}\right)\end{array}$ & $9.1 \%$ & $65.5 \%$ & $21.8 \%$ & $3.6 \%$ \\
\hline $72-96$ & $\begin{array}{l}2 \times \text { MAT; } 3 \times \text { TRIAX; } \\
48 \times \text { C } 260\left(0^{\circ}\right) ; \\
8 \times \text { AS/H3501 }\left(0^{\circ}\right)\end{array}$ & $11.9 \%$ & $71.6 \%$ & $13.4 \%$ & $3.0 \%$ \\
\hline $96-120$ & $\begin{array}{l}2 \times \text { MAT; } 3 \times \text { TRIAX; } \\
42 \times \text { C } 260\left(0^{\circ}\right) ; \\
7 \times \text { AS } / \mathrm{H} 3501\left(0^{\circ}\right)\end{array}$ & $11.7 \%$ & $70.0 \%$ & $15.0 \%$ & $3.3 \%$ \\
\hline $120-144$ & $\begin{array}{l}2 \times \text { MAT; } 2 \times \text { TRIAX; } \\
33 \times \text { C } 260\left(0^{\circ}\right) ; \\
7 \times \text { AS/H3501 }\left(0^{\circ}\right)\end{array}$ & $14.6 \%$ & $68.8 \%$ & $12.5 \%$ & $4.2 \%$ \\
\hline $144-168$ & $\begin{array}{l}2 \times \text { MAT; } 2 \times \text { TRIAX; } \\
33 \times \text { C } 260\left(0^{\circ}\right) ; \\
7 \times \text { AS/H3501 }\left(0^{\circ}\right)\end{array}$ & $14.6 \%$ & $68.8 \%$ & $12.5 \%$ & $4.2 \%$ \\
\hline $168-192$ & $\begin{array}{l}2 \times \text { MAT; } 2 \times \text { TRIAX; } \\
25 \times \text { C } 260\left(0^{\circ}\right) ; \\
5 \times \text { AS/H3501 }\left(0^{\circ}\right)\end{array}$ & $13.2 \%$ & $65.8 \%$ & $15.8 \%$ & $5.3 \%$ \\
\hline $192-216$ & $\begin{array}{l}2 \times \text { MAT; } 2 \times \text { TRIAX; } \\
18 \times \text { C } 260\left(0^{\circ}\right) ; \\
4 \times \text { AS } / \mathrm{H} 3501\left(0^{\circ}\right)\end{array}$ & $13.3 \%$ & $60.0 \%$ & $20.0 \%$ & $6.7 \%$ \\
\hline $216-240$ & $\begin{array}{l}2 \times \text { MAT; } 2 \times \text { TRIAX; } \\
18 \times \text { C } 260\left(0^{\circ}\right) ; \\
4 \times \text { AS } / H 3501\left(0^{\circ}\right)\end{array}$ & $13.3 \%$ & $60.0 \%$ & $20.0 \%$ & $6.7 \%$ \\
\hline $240-264$ & $\begin{array}{l}2 \times \text { MAT; } 2 \times \text { TRIAX; } \\
15 \times \text { C } 260\left(0^{\circ}\right) ; \\
4 \times \text { AS } / H 3501\left(0^{\circ}\right)\end{array}$ & $14.8 \%$ & $55.6 \%$ & $22.2 \%$ & $7.4 \%$ \\
\hline $264-288$ & $\begin{array}{l}2 \times \mathrm{MAT} ; 2 \times \mathrm{TRIAX} ; \\
15 \times \mathrm{C} 260\left(0^{\circ}\right) ; \\
4 \times \mathrm{AS} / \mathrm{H} 3501\left(0^{\circ}\right)\end{array}$ & $14.8 \%$ & $55.6 \%$ & $22.2 \%$ & $7.4 \%$ \\
\hline $288-312$ & $2 \times$ MAT; $6 \times$ TRIAX & $0.0 \%$ & $0.0 \%$ & $90.0 \%$ & $10.0 \%$ \\
\hline Spar & $4 \times$ TRIAX & $0.0 \%$ & $0.0 \%$ & $90.0 \%$ & $10.0 \%$ \\
\hline
\end{tabular}

*: The first number is the number of layers (i.e. $2 \times$ MAT means 2 layers of MAT material). 
Table 3.4 Laminate Lay-up for SERI-8 Enhanced Model (without bend-twistcoupling) with $60 \%$ Unidirectional Glass Replacement

\begin{tabular}{|c|c|c|c|c|c|}
\hline Station & Laminate Lay-up & $\begin{array}{c}\text { Volume } \\
\text { Fraction of } \\
\text { AS/H3501 }\end{array}$ & $\begin{array}{c}\text { Volume } \\
\text { Fraction of } \\
\text { C260 Material }\end{array}$ & $\begin{array}{l}\text { Volume } \\
\text { Fraction of } \\
\text { TRIAX }\end{array}$ & $\begin{array}{l}\text { Volume } \\
\text { Fraction of } \\
\text { MAT }\end{array}$ \\
\hline $0-24$ & $\begin{array}{l}2 \text { x MAT; } 4 \text { x TRIAX; } \\
75 \text { x C } 260\left(90^{\circ}\right)\end{array}$ & $0.0 \%$ & $84.3 \%$ & $13.5 \%$ & $2.2 \%$ \\
\hline $24-48$ & $\begin{array}{l}2 \times \text { MAT; } 4 \times \text { TRIAX; } \\
16 \times \text { C260 }\left(0^{\circ}\right) ; \\
8 \times \mathrm{AS} / \mathrm{H} 3501\left(0^{\circ}\right)\end{array}$ & $21.1 \%$ & $42.1 \%$ & $31.6 \%$ & $5.3 \%$ \\
\hline $48-72$ & $\begin{array}{l}2 \times \text { MAT; } 4 \text { x TRIAX; } \\
24 \times \text { C } 260\left(0^{\circ}\right) ; \\
12 \times \text { AS/H3501 }\left(0^{\circ}\right)\end{array}$ & $24.0 \%$ & $48.0 \%$ & $24.0 \%$ & $4.0 \%$ \\
\hline $72-96$ & $\begin{array}{l}2 \times \text { MAT; } 3 \times \text { TRIAX; } \\
32 \times \text { C } 260\left(0^{\circ}\right) ; \\
16 \times \text { AS } / H 3501\left(0^{\circ}\right)\end{array}$ & $27.1 \%$ & $54.2 \%$ & $15.3 \%$ & $3.4 \%$ \\
\hline $96-120$ & $\begin{array}{l}2 \times \text { MAT; } 3 \times \text { TRIAX; } \\
28 \times \text { C } 260\left(0^{\circ}\right) ; \\
14 \times \text { AS/H } 3501\left(0^{\circ}\right)\end{array}$ & $26.4 \%$ & $52.8 \%$ & $17.0 \%$ & $3.8 \%$ \\
\hline $120-144$ & $\begin{array}{l}2 \times \text { MAT; } 2 \times \text { TRIAX; } \\
22 \times \mathrm{C} 260\left(0^{\circ}\right) ; \\
11 \times \mathrm{AS} / \mathrm{H} 3501\left(0^{\circ}\right)\end{array}$ & $26.8 \%$ & $53.7 \%$ & $14.6 \%$ & $4.9 \%$ \\
\hline $144-168$ & $\begin{array}{l}2 \times \text { MAT } ; 2 \times \text { TRIAX; } \\
22 \times \mathrm{C} 260\left(0^{\circ}\right) ; \\
11 \times \mathrm{AS} / \mathrm{H} 3501\left(0^{\circ}\right)\end{array}$ & $26.8 \%$ & $53.7 \%$ & $14.6 \%$ & $4.9 \%$ \\
\hline $168-192$ & $\begin{array}{l}2 \times \text { MAT; } 2 \times \text { TRIAX; } \\
17 \times \text { C } 260\left(0^{\circ}\right) ; \\
8 \times \text { AS/H } 3501\left(0^{\circ}\right) \\
\end{array}$ & $24.2 \%$ & $51.5 \%$ & $18.2 \%$ & $6.1 \%$ \\
\hline $192-216$ & $\begin{array}{l}2 \times \text { MAT } ; 2 \times \text { TRLAX; } \\
12 \times \mathrm{C} 260\left(0^{\circ}\right) ; \\
6 \times \mathrm{AS} / \mathrm{H} 3501\left(0^{\circ}\right) \\
\end{array}$ & $23.1 \%$ & $46.2 \%$ & $23.1 \%$ & $7.7 \%$ \\
\hline $216-240$ & $\begin{array}{l}2 \times \text { MAT; } 2 \times \text { TRIAX; } \\
12 \times \text { C } 260\left(0^{\circ}\right) ; \\
6 \times \text { AS } / H 3501\left(0^{\circ}\right) \\
\end{array}$ & $23.1 \%$ & $46.2 \%$ & $23.1 \%$ & $7.7 \%$ \\
\hline $240-264$ & $\begin{array}{l}2 \times \text { MAT } ; 2 \times \text { TRIAX; } \\
10 \times \mathrm{C} 260\left(0^{\circ}\right) ; \\
5 \times \mathrm{AS} / \mathrm{H} 3501\left(0^{\circ}\right)\end{array}$ & $21.7 \%$ & $43.5 \%$ & $26.1 \%$ & $8.7 \%$ \\
\hline $264-288$ & $\begin{array}{l}2 \times \text { MAT; } 2 \times \text { TRIAX; } \\
10 \times \mathrm{C} 260\left(0^{\circ}\right) ; \\
5 \times \mathrm{AS} / \mathrm{H} 3501\left(0^{\circ}\right)\end{array}$ & $21.7 \%$ & $43.5 \%$ & $26.1 \%$ & $8.7 \%$ \\
\hline $288-312$ & 2 x MAT; 6 x TRIAX & $0.0 \%$ & $0.0 \%$ & $90.0 \%$ & $10.0 \%$ \\
\hline Spar & $4 \times$ TRIAX & $0.0 \%$ & $0.0 \%$ & $90.0 \%$ & $10.0 \%$ \\
\hline
\end{tabular}

*: The first number is the number of layers (i.e. 2 x MAT means 2 layers of MAT material). 
Table 3.5 Laminate Lay-up for SERI-8 Enhanced Model (without bend-twistcoupling) with $80 \%$ Unidirectional Glass Replacement

\begin{tabular}{|c|c|c|c|c|c|}
\hline Station & Laminate Lay-up ${ }^{*}$ & $\begin{array}{l}\text { Volume } \\
\text { Fraction of } \\
\text { AS/H3501 }\end{array}$ & $\begin{array}{c}\text { Volume } \\
\text { Fraction of } \\
\text { C260 Material }\end{array}$ & $\begin{array}{l}\text { Volume } \\
\text { Fraction of } \\
\text { TRIAX }\end{array}$ & $\begin{array}{l}\text { Volume } \\
\text { Fraction of } \\
\text { MAT }\end{array}$ \\
\hline $0-24$ & $\begin{array}{l}2 \times \text { MAT; } 4 \times \text { TRIAX; } \\
75 \times \text { C } 260\left(90^{\circ}\right)\end{array}$ & $0.0 \%$ & $84.3 \%$ & $13.5 \%$ & $2.2 \%$ \\
\hline $24-48$ & $\begin{array}{l}2 \times \mathrm{MAT} ; 4 \times \text { TRIAX; } \\
8 \times \mathrm{C} 260\left(0^{\circ}\right) \\
10 \times \mathrm{AS} / \mathrm{H} 3501\left(0^{\circ}\right)\end{array}$ & $31.3 \%$ & $25.0 \%$ & $37.5 \%$ & $6.3 \%$ \\
\hline $48-72$ & $\begin{array}{l}2 \times \mathrm{MAT} ; 4 \times \mathrm{TRIAX} ; \\
12 \times \mathrm{C} 260\left(0^{\circ}\right) ; \\
15 \times \mathrm{AS} / \mathrm{H} 3501\left(0^{\circ}\right) \\
\end{array}$ & $36.6 \%$ & $29.3 \%$ & $29.3 \%$ & $4.9 \%$ \\
\hline $72-96$ & $\begin{array}{l}2 \times \mathrm{MAT} ; 3 \times \mathrm{TRIAX} \\
16 \times \mathrm{C} 260\left(0^{\circ}\right) ; \\
20 \times \mathrm{AS} / \mathrm{H} 3501\left(0^{\circ}\right)\end{array}$ & $42.6 \%$ & $34.0 \%$ & $19.1 \%$ & $4.3 \%$ \\
\hline $96-120$ & $\begin{array}{l}2 \times \mathrm{MAT} ; 3 \times \text { TRIAX; } \\
14 \times \mathrm{C} 260\left(0^{\circ}\right) ; \\
18 \times \mathrm{AS} / \mathrm{H} 3501\left(0^{\circ}\right) \\
\end{array}$ & $41.9 \%$ & $32.6 \%$ & $20.9 \%$ & $4.7 \%$ \\
\hline $120-144$ & $\begin{array}{l}2 \times \mathrm{MAT} ; 2 \times \mathrm{TRIAX} \\
11 \times \mathrm{C} 260\left(0^{\circ}\right) \\
14 \times \mathrm{AS} / \mathrm{H} 3501\left(0^{\circ}\right)\end{array}$ & $42.4 \%$ & $33.3 \%$ & $18.2 \%$ & $6.1 \%$ \\
\hline $144-168$ & $\begin{array}{l}2 \times \text { MAT; } 2 \times \text { TRIAX; } \\
11 \times \text { C } 260\left(0^{\circ}\right) ; \\
14 \times \text { AS } / H 3501\left(0^{\circ}\right)\end{array}$ & $42.4 \%$ & $33.3 \%$ & $18.2 \%$ & $6.1 \%$ \\
\hline $168-192$ & $\begin{array}{l}2 \times \mathrm{MAT} ; 2 \times \mathrm{TRIAX} \\
8 \times \mathrm{C} 260\left(0^{\circ}\right) ; \\
10 \times \mathrm{AS} / \mathrm{H} 3501\left(0^{\circ}\right) \\
\end{array}$ & $38.5 \%$ & $30.8 \%$ & $23.1 \%$ & $7.7 \%$ \\
\hline $192-216$ & $\begin{array}{l}2 \times \text { MAT; } 2 \times \text { TRIAX; } \\
6 \times \mathrm{C} 260\left(0^{\circ}\right) ; \\
7 \times \text { AS } / \mathrm{H} 3501\left(0^{\circ}\right) \\
\end{array}$ & $33.3 \%$ & $28.6 \%$ & $28.6 \%$ & $9.5 \%$ \\
\hline $216-240$ & $\begin{array}{l}2 \times \mathrm{MAT} ; 2 \times \text { TRIAX; } \\
6 \times \mathrm{C} 260\left(0^{\circ}\right) \\
7 \times \mathrm{AS} / \mathrm{H} 3501\left(0^{\circ}\right)\end{array}$ & $33.3 \%$ & $28.6 \%$ & $28.6 \%$ & $9.5 \%$ \\
\hline $240-264$ & $\begin{array}{l}2 \times \mathrm{MAT} ; 2 \times \mathrm{TRIAX} \\
5 \times \mathrm{C} 260\left(0^{\circ}\right) \\
6 \times \mathrm{AS} / \mathrm{H} 3501\left(0^{\circ}\right)\end{array}$ & $31.6 \%$ & $26.3 \%$ & $31.6 \%$ & $10.5 \%$ \\
\hline $264-288$ & $\begin{array}{l}2 \times \text { MAT; } 2 \times \text { TRIAX; } \\
5 \times \mathrm{C} 260\left(0^{\circ}\right) \\
6 \times \mathrm{AS} / \mathrm{H} 3501\left(0^{\circ}\right)\end{array}$ & $31.6 \%$ & $26.3 \%$ & $31.6 \%$ & $10.5 \%$ \\
\hline $288-312$ & $2 \times$ MAT; $6 \times$ TRIAX & $0.0 \%$ & $0.0 \%$ & $90.0 \%$ & $10.0 \%$ \\
\hline Spar & $4 \times$ TRIAX & $0.0 \%$ & $0.0 \%$ & $90.0 \%$ & $10.0 \%$ \\
\hline
\end{tabular}

*: The first number is the number of layers (i.e. $2 \times$ MAT means 2 layers of MAT material). 
Table 3.6 Laminate Lay-up for SERI-8 Enhanced Model (without bend-twistcoupling) with $100 \%$ Unidirectional Glass Replacement

\begin{tabular}{|c|c|c|c|c|c|}
\hline Station & Laminate Lay-up ${ }^{*}$ & $\begin{array}{l}\text { Volume } \\
\text { Fraction of } \\
\text { AS/H3501 }\end{array}$ & $\begin{array}{c}\text { Volume } \\
\text { Fraction of } \\
\text { C260 Material }\end{array}$ & $\begin{array}{l}\text { Volume } \\
\text { Fraction of } \\
\text { TRIAX }\end{array}$ & $\begin{array}{l}\text { Volume } \\
\text { Fraction of } \\
\text { MAT }\end{array}$ \\
\hline $0-24$ & $\begin{array}{l}2 \times \text { MAT } ; 4 \times \text { TRIAX; } \\
75 \times \text { C } 260\left(90^{\circ}\right)\end{array}$ & $0.0 \%$ & $84.3 \%$ & $13.5 \%$ & $2.2 \%$ \\
\hline $24-48$ & $\begin{array}{l}2 \times \text { MAT; } 4 \times \text { TRIAX; } \\
12 \times \text { AS } / \mathrm{H} 3501\left(0^{\circ}\right)\end{array}$ & $46.2 \%$ & $0.0 \%$ & $46.2 \%$ & $7.7 \%$ \\
\hline $48-72$ & $\begin{array}{l}2 \times \text { MAT } ; 4 \times \text { TRIAX; } \\
19 \times \text { AS } / \mathrm{H} 3501\left(0^{\circ}\right)\end{array}$ & $57.6 \%$ & $0.0 \%$ & $36.4 \%$ & $6.1 \%$ \\
\hline $72-96$ & $\begin{array}{l}2 \times \text { MAT } ; 3 \times \text { TRIAX; } \\
25 \times \text { AS } / \mathrm{H} 3501\left(0^{\circ}\right)\end{array}$ & $69.4 \%$ & $0.0 \%$ & $25.0 \%$ & $5.6 \%$ \\
\hline $96-120$ & $\begin{array}{l}2 \times \text { MAT; } 3 \times \text { TRIAX; } \\
22 \times \text { AS } / H 3501\left(0^{\circ}\right)\end{array}$ & $66.7 \%$ & $0.0 \%$ & $27.3 \%$ & $6.1 \%$ \\
\hline $120-144$ & $\begin{array}{l}2 \times \mathrm{MAT} ; 2 \times \text { TRIAX; } \\
17 \times \mathrm{AS} / \mathrm{H} 3501\left(0^{\circ}\right)\end{array}$ & $68.0 \%$ & $0.0 \%$ & $24.0 \%$ & $8.0 \%$ \\
\hline $144-168$ & $\begin{array}{l}2 \times \text { MAT } ; 2 \times \text { TRIAX; } \\
17 \times \text { AS } / \mathrm{H} 3501\left(0^{\circ}\right)\end{array}$ & $68.0 \%$ & $0.0 \%$ & $24.0 \%$ & $8.0 \%$ \\
\hline $168-192$ & $\begin{array}{l}2 \times \text { MAT } ; 2 \times \text { TRIAX; } \\
13 \times \text { AS } / \mathrm{H} 3501\left(0^{\circ}\right)\end{array}$ & $61.9 \%$ & $0.0 \%$ & $28.6 \%$ & $9.5 \%$ \\
\hline $192-216$ & $\begin{array}{l}2 \times \text { MAT } ; 2 \times \text { TRIAX; } \\
9 \times \text { AS } / \mathrm{H} 3501\left(0^{\circ}\right)\end{array}$ & $52.9 \%$ & $0.0 \%$ & $35.3 \%$ & $11.8 \%$ \\
\hline $216-240$ & $\begin{array}{l}2 \times \text { MAT; } 2 \times \text { TRIAX; } \\
9 \times \text { AS } / \mathrm{H} 3501\left(0^{\circ}\right)\end{array}$ & $52.9 \%$ & $0.0 \%$ & $35.3 \%$ & $11.8 \%$ \\
\hline $240-264$ & $\begin{array}{l}2 \times \text { MAT; } 2 \times \text { TRIAX; } \\
7 \times \text { AS } / \mathrm{H} 3501\left(0^{\circ}\right)\end{array}$ & $46.7 \%$ & $0.0 \%$ & $40.0 \%$ & $13.3 \%$ \\
\hline $264-288$ & $\begin{array}{l}2 \times \mathrm{MAT} ; 2 \times \text { TRIAX; } \\
7 \times \text { AS } / \mathrm{H} 3501\left(0^{\circ}\right)\end{array}$ & $46.7 \%$ & $0.0 \%$ & $40.0 \%$ & $13.3 \%$ \\
\hline $288-312$ & $2 \times$ MAT; $6 \times$ TRIAX & $0.0 \%$ & $0.0 \%$ & $90.0 \%$ & $10.0 \%$ \\
\hline Spar & $4 \times$ TRIAX & $0.0 \%$ & $0.0 \%$ & $90.0 \%$ & $10.0 \%$ \\
\hline
\end{tabular}

*: The first number is the number of layers (i.e. $2 \times$ MAT means 2 layers of MAT material). 
Table 3.7 Laminate Lay-up for SERI-8 Enhanced Model (with bend-twist-coupling) with $20 \%$ Unidirectional Glass Replacement

\begin{tabular}{|c|c|c|c|c|c|}
\hline Station & Laminate Lay-up ${ }^{*}$ & $\begin{array}{l}\text { Volume } \\
\text { Fraction of } \\
\text { AS/H3501 }\end{array}$ & $\begin{array}{c}\text { Volume } \\
\text { Fraction of } \\
\text { C260 Material }\end{array}$ & $\begin{array}{l}\text { Volume } \\
\text { Fraction of } \\
\text { TRIAX }\end{array}$ & $\begin{array}{l}\text { Volume } \\
\text { Fraction of } \\
\text { MAT }\end{array}$ \\
\hline $0-24$ & $\begin{array}{l}2 \text { x MAT; } 4 \text { x TRIAX; } \\
75 \text { x C } 260\left(90^{\circ}\right)\end{array}$ & $0.0 \%$ & $84.3 \%$ & $13.5 \%$ & $2.2 \%$ \\
\hline $24-48$ & $\begin{array}{l}2 \times \text { MAT; } 4 \times \text { TRIAX; } \\
32 \text { x C260 }\left(0^{\circ}\right) ; \\
4 \times \text { AS/H } 3501\left(20^{\circ}\right)\end{array}$ & $8.0 \%$ & $64.0 \%$ & $24.0 \%$ & $4.0 \%$ \\
\hline $48-72$ & $\begin{array}{l}2 \times \text { MAT; } 4 \times \text { TRIAX; } \\
48 \times \text { C } 260\left(0^{\circ}\right) ; \\
5 \times \text { AS/H } 3501\left(20^{\circ}\right)\end{array}$ & $7.5 \%$ & $71.6 \%$ & $17.9 \%$ & $3.0 \%$ \\
\hline $72-96$ & $\begin{array}{l}2 \times \text { MAT; } 3 \times \text { TRIAX; } \\
64 \times \text { C } 260\left(0^{\circ}\right) ; \\
6 \times \text { AS/H } 3501\left(20^{\circ}\right)\end{array}$ & $7.4 \%$ & $79.0 \%$ & $11.1 \%$ & $2.5 \%$ \\
\hline $96-120$ & $\begin{array}{l}2 \times \text { MAT; } 3 \times \text { TRIAX; } \\
56 \times \text { C } 260\left(0^{\circ}\right) ; \\
5 \times \text { AS/H } 3501\left(20^{\circ}\right)\end{array}$ & $6.9 \%$ & $77.8 \%$ & $12.5 \%$ & $2.8 \%$ \\
\hline $120-144$ & $\begin{array}{l}2 \times \text { MAT; } 2 \times \text { TRIAX; } \\
44 \times \text { C } 260\left(0^{\circ}\right) ; \\
5 \times \text { AS/H3501 }\left(20^{\circ}\right)\end{array}$ & $8.8 \%$ & $77.2 \%$ & $10.5 \%$ & $3.5 \%$ \\
\hline $144-168$ & $\begin{array}{l}2 \times \text { MAT; } 2 \times \text { TRIAX; } \\
44 \times \text { C } 260\left(0^{\circ}\right) ; \\
5 \times \text { AS/H } 3501\left(20^{\circ}\right)\end{array}$ & $8.8 \%$ & $77.2 \%$ & $10.5 \%$ & $3.5 \%$ \\
\hline $168-192$ & $\begin{array}{l}2 \times \text { MAT; } 2 \times \text { TRIAX; } \\
34 \times \text { C } 260\left(0^{\circ}\right) ; \\
4 \times \text { AS/H } 3501\left(20^{\circ}\right)\end{array}$ & $8.7 \%$ & $73.9 \%$ & $13.0 \%$ & $4.3 \%$ \\
\hline $192-216$ & $\begin{array}{l}2 \times \mathrm{MAT} ; 2 \times \mathrm{TRIAX} ; \\
24 \times \mathrm{C} 260\left(0^{\circ}\right) ; \\
3 \times \mathrm{AS} / \mathrm{H} 3501\left(20^{\circ}\right)\end{array}$ & $8.6 \%$ & $68.6 \%$ & $17.1 \%$ & $5.7 \%$ \\
\hline $216-240$ & $\begin{array}{l}2 \times \text { MAT; } 2 \times \text { TRIAX; } \\
24 \times \text { C } 260\left(0^{\circ}\right) ; \\
3 \times \text { AS/H } 3501\left(20^{\circ}\right)\end{array}$ & $8.6 \%$ & $68.6 \%$ & $17.1 \%$ & $5.7 \%$ \\
\hline $240-264$ & $\begin{array}{l}2 \times \text { MAT; } 2 \times \text { TRIAX; } \\
20 \times \text { C } 260\left(0^{\circ}\right) ; \\
2 \times \text { AS/H } 3501\left(20^{\circ}\right)\end{array}$ & $6.7 \%$ & $66.7 \%$ & $20.0 \%$ & $6.7 \%$ \\
\hline $264-288$ & $\begin{array}{l}2 \times \text { MAT; } 2 \times \text { TRIAX; } \\
20 \times \text { C260 }\left(0^{\circ}\right) ; \\
2 \times \text { AS/H } 3501\left(20^{\circ}\right)\end{array}$ & $6.7 \%$ & $66.7 \%$ & $20.0 \%$ & $6.7 \%$ \\
\hline $288-312$ & $2 \times$ MAT; 6 x TRIAX & $0.0 \%$ & $0.0 \%$ & $90.0 \%$ & $10.0 \%$ \\
\hline Spar & $4 \times$ TRIAX & $0.0 \%$ & $0.0 \%$ & $90.0 \%$ & $10.0 \%$ \\
\hline
\end{tabular}

*: The first number is the number of layers (i.e. $2 \times$ MAT means 2 layers of MAT material). 
Table 3.8 Laminate Lay-up for SERI-8 Enhanced Model (with bend-twist-coupling) with 40\% Unidirectional Glass Replacement

\begin{tabular}{|c|c|c|c|c|c|}
\hline Station & Laminate Lay-up & $\begin{array}{l}\text { Volume } \\
\text { Fraction of } \\
\text { AS/H3501 }\end{array}$ & $\begin{array}{c}\text { Volume } \\
\text { Fraction of } \\
\text { C260 Material }\end{array}$ & $\begin{array}{l}\text { Volume } \\
\text { Fraction of } \\
\text { TRIAX }\end{array}$ & $\begin{array}{l}\text { Volume } \\
\text { Fraction of } \\
\text { MAT }\end{array}$ \\
\hline $0-24$ & $\begin{array}{l}2 \times \text { MAT; } 4 \times \text { TRIAX; } \\
75 \times \mathrm{C} 260\left(90^{\circ}\right)\end{array}$ & $0.0 \%$ & $84.3 \%$ & $13.5 \%$ & $2.2 \%$ \\
\hline $24-48$ & $\begin{array}{l}2 \times \text { MAT; } 4 \times \text { TRIAX; } \\
24 \times \text { C } 260\left(0^{\circ}\right) \\
7 \times \text { AS/H3501 }\left(20^{\circ}\right)\end{array}$ & $15.6 \%$ & $53.3 \%$ & $26.7 \%$ & $4.4 \%$ \\
\hline $48-72$ & $\begin{array}{l}2 \times \text { MAT; } 4 \times \text { TRIAX; } \\
36 \times \mathrm{C} 260\left(0^{\circ}\right) ; \\
10 \times \mathrm{AS} / \mathrm{H} 3501\left(20^{\circ}\right)\end{array}$ & $16.7 \%$ & $60.0 \%$ & $20.0 \%$ & $3.3 \%$ \\
\hline $72-96$ & $\begin{array}{l}2 \times \text { MAT; } 3 \times \text { TRIAX; } \\
48 \times \text { C } 260\left(0^{\circ}\right) ; \\
13 \times \text { AS } / \mathrm{H} 3501\left(20^{\circ}\right)\end{array}$ & $18.1 \%$ & $66.7 \%$ & $12.5 \%$ & $2.8 \%$ \\
\hline $96-120$ & $\begin{array}{l}2 \times \text { MAT; } 3 \times \text { TRIAX; } \\
42 \times \mathrm{C} 260\left(0^{\circ}\right) ; \\
12 \times \mathrm{AS} / \mathrm{H} 3501\left(20^{\circ}\right)\end{array}$ & $18.5 \%$ & $64.6 \%$ & $13.8 \%$ & $3.1 \%$ \\
\hline $120-144$ & $\begin{array}{l}2 \times \text { MAT; } 2 \times \text { TRIAX; } \\
33 \times \text { C } 260\left(0^{\circ}\right) \\
9 \times \text { AS } / \mathrm{H} 3501\left(20^{\circ}\right)\end{array}$ & $18.0 \%$ & $66.0 \%$ & $12.0 \%$ & $4.0 \%$ \\
\hline $144-168$ & $\begin{array}{l}2 \times \mathrm{MAT} ; 2 \times \text { TRIAX; } \\
33 \times \mathrm{C} 260\left(0^{\circ}\right) ; \\
9 \times \mathrm{AS} / \mathrm{H} 3501\left(20^{\circ}\right)\end{array}$ & $18.0 \%$ & $66.0 \%$ & $12.0 \%$ & $4.0 \%$ \\
\hline $168-192$ & $\begin{array}{l}2 \times \text { MAT; } 2 \times \text { TRIAX; } \\
25 \times \mathrm{C} 260\left(0^{\circ}\right) ; \\
7 \times \text { AS } / \mathrm{H} 3501\left(20^{\circ}\right)\end{array}$ & $17.5 \%$ & $62.5 \%$ & $15.0 \%$ & $5.0 \%$ \\
\hline $192-216$ & $\begin{array}{l}2 \times \text { MAT; } 2 \times \text { TRIAX; } \\
18 \times \text { C } 260\left(0^{\circ}\right) \\
5 \times \text { AS/H } 3501\left(20^{\circ}\right)\end{array}$ & $16.1 \%$ & $58.1 \%$ & $19.4 \%$ & $6.5 \%$ \\
\hline $216-240$ & $\begin{array}{l}2 \times \text { MAT; } 2 \times \text { TRIAX; } \\
18 \times \mathrm{C} 260\left(0^{\circ}\right) ; \\
5 \times \mathrm{AS} / \mathrm{H} 3501\left(20^{\circ}\right)\end{array}$ & $16.1 \%$ & $58.1 \%$ & $19.4 \%$ & $6.5 \%$ \\
\hline $240-264$ & $\begin{array}{l}2 \times \text { MAT; } 2 \times \text { TRIAX; } \\
15 \times \text { C } 260\left(0^{\circ}\right) ; \\
5 \times \text { AS/H } 3501\left(20^{\circ}\right)\end{array}$ & $17.9 \%$ & $53.6 \%$ & $21.4 \%$ & $7.1 \%$ \\
\hline $264-288$ & $\begin{array}{l}2 \times \text { MAT; } 2 \times \text { TRIAX; } \\
15 \times \text { C } 260\left(0^{\circ}\right) ; \\
5 \times \text { AS/H3501 }\left(20^{\circ}\right)\end{array}$ & $17.9 \%$ & $53.6 \%$ & $21.4 \%$ & $7.1 \%$ \\
\hline $288-312$ & $2 \times$ MAT; $6 \times$ TRIAX & $0.0 \%$ & $0.0 \%$ & $90.0 \%$ & $10.0 \%$ \\
\hline Spar & $4 \times$ TRIAX & $0.0 \%$ & $0.0 \%$ & $90.0 \%$ & $10.0 \%$ \\
\hline
\end{tabular}

*: The first number is the number of layers (i.e. $2 \times$ MAT means 2 layers of MAT material). 
Table 3.9 Laminate Lay-up for SERI-8 Enhanced Model (with bend-twist-coupling) with $60 \%$ Unidirectional Glass Replacement

\begin{tabular}{|c|c|c|c|c|c|}
\hline Station & Laminate Lay-up & $\begin{array}{l}\text { Volume } \\
\text { Fraction of } \\
\text { AS/H3501 }\end{array}$ & $\begin{array}{c}\text { Volume } \\
\text { Fraction of } \\
\text { C260 Material }\end{array}$ & $\begin{array}{l}\text { Volume } \\
\text { Fraction of } \\
\text { TRIAX }\end{array}$ & $\begin{array}{l}\text { Volume } \\
\text { Fraction of } \\
\text { MAT }\end{array}$ \\
\hline $0-24$ & $\begin{array}{l}2 \text { x MAT; } 4 \text { x TRIAX; } \\
75 \text { x C260 }\left(90^{\circ}\right)\end{array}$ & $0.0 \%$ & $84.3 \%$ & $13.5 \%$ & $2.2 \%$ \\
\hline $24-48$ & $\begin{array}{l}2 \times \mathrm{MAT} ; 4 \times \text { TRIAX; } \\
16 \times \mathrm{C} 260\left(0^{\circ}\right) ; \\
11 \times \mathrm{AS} / \mathrm{H} 3501\left(20^{\circ}\right)\end{array}$ & $26.8 \%$ & $39.0 \%$ & $29.3 \%$ & $4.9 \%$ \\
\hline $48-72$ & $\begin{array}{l}2 \times \text { MAT; } 4 \times \text { TRIAX; } \\
24 \times \text { C } 260\left(0^{\circ}\right) ; \\
20 \times \text { AS/H3501 }\left(20^{\circ}\right)\end{array}$ & $34.5 \%$ & $41.4 \%$ & $20.7 \%$ & $3.4 \%$ \\
\hline $72-96$ & $\begin{array}{l}2 \times \mathrm{MAT} ; 3 \times \text { TRIAX; } \\
32 \times \mathrm{C} 260\left(0^{\circ}\right) ; \\
20 \times \mathrm{AS} / \mathrm{H} 3501\left(20^{\circ}\right)\end{array}$ & $31.7 \%$ & $50.8 \%$ & $14.3 \%$ & $3.2 \%$ \\
\hline $96-120$ & $\begin{array}{l}2 \times \mathrm{MAT} ; 3 \times \text { TRIAX; } \\
28 \times \mathrm{C} 260\left(0^{\circ}\right) ; \\
18 \times \mathrm{AS} / \mathrm{H} 3501\left(20^{\circ}\right)\end{array}$ & $31.6 \%$ & $49.1 \%$ & $15.8 \%$ & $3.5 \%$ \\
\hline $120-144$ & $\begin{array}{l}2 \times \text { MAT; } 2 \times \text { TRIAX; } \\
22 \times \text { C } 260\left(0^{\circ}\right) ; \\
14 \times \text { AS } / \mathrm{H} 3501\left(20^{\circ}\right)\end{array}$ & $31.8 \%$ & $50.0 \%$ & $13.6 \%$ & $4.5 \%$ \\
\hline $144-168$ & $\begin{array}{l}2 \times \text { MAT; } 2 \times \text { TRIAX; } \\
22 \times \text { C } 260\left(0^{\circ}\right) ; \\
14 \times \text { AS } / \mathrm{H} 3501\left(20^{\circ}\right)\end{array}$ & $31.8 \%$ & $50.0 \%$ & $13.6 \%$ & $4.5 \%$ \\
\hline $168-192$ & $\begin{array}{l}2 \times \text { MAT; } 2 \times \text { TRIAX; } \\
17 \times \text { C } 260\left(0^{\circ}\right) \\
11 \times \text { AS/H3501 }\left(20^{\circ}\right)\end{array}$ & $30.6 \%$ & $47.2 \%$ & $16.7 \%$ & $5.6 \%$ \\
\hline $192-216$ & $\begin{array}{l}2 \times \mathrm{MAT} ; 2 \times \text { TRIAX; } \\
12 \times \mathrm{C} 260\left(0^{\circ}\right) \\
8 \times \mathrm{AS} / \mathrm{H} 3501\left(20^{\circ}\right)\end{array}$ & $28.6 \%$ & $42.9 \%$ & $21.4 \%$ & $7.1 \%$ \\
\hline $216-240$ & $\begin{array}{l}2 \times \mathrm{MAT} ; 2 \times \text { TRIAX; } \\
12 \times \mathrm{C} 260\left(0^{\circ}\right) ; \\
8 \times \mathrm{AS} / \mathrm{H} 3501\left(20^{\circ}\right)\end{array}$ & $28.6 \%$ & $42.9 \%$ & $21.4 \%$ & $7.1 \%$ \\
\hline $240-264$ & $\begin{array}{l}2 \times \mathrm{MAT} ; 2 \times \text { TRIAX; } \\
10 \times \mathrm{C} 260\left(0^{\circ}\right) ; \\
7 \times \mathrm{AS} / \mathrm{H} 3501\left(20^{\circ}\right)\end{array}$ & $28.0 \%$ & $40.0 \%$ & $24.0 \%$ & $8.0 \%$ \\
\hline $264-288$ & $\begin{array}{l}2 \times \mathrm{MAT} ; 2 \times \text { TRIAX; } \\
10 \times \mathrm{C} 260\left(0^{\circ}\right) ; \\
7 \times \mathrm{AS} / \mathrm{H} 3501\left(20^{\circ}\right)\end{array}$ & $28.0 \%$ & $40.0 \%$ & $24.0 \%$ & $8.0 \%$ \\
\hline $288-312$ & $2 \times$ MAT; $6 \times$ TRIAX & $0.0 \%$ & $0.0 \%$ & $90.0 \%$ & $10.0 \%$ \\
\hline Spar & $4 \mathrm{x}$ TRIAX & $0.0 \%$ & $0.0 \%$ & $90.0 \%$ & $10.0 \%$ \\
\hline
\end{tabular}

*: The first number is the number of layers (i.e. $2 \times$ MAT means 2 layers of MAT material). 
Table 3.10 Laminate Lay-up for SERI-8 Enhanced Model (with bend-twist-coupling) with $80 \%$ Unidirectional Glass Replacement

\begin{tabular}{|c|c|c|c|c|c|}
\hline Station & Laminate Lay-up* & $\begin{array}{c}\text { Volume } \\
\text { Fraction of } \\
\text { AS/H3501 }\end{array}$ & $\begin{array}{c}\text { Volume } \\
\text { Fraction of } \\
\text { C260 Material }\end{array}$ & $\begin{array}{l}\text { Volume } \\
\text { Fraction of } \\
\text { TRIAX }\end{array}$ & $\begin{array}{l}\text { Volume } \\
\text { Fraction of } \\
\text { MAT }\end{array}$ \\
\hline $0-24$ & $\begin{array}{l}2 \times \text { MAT; } 4 \times \text { TRIAX; } \\
75 \times \text { C } 260\left(90^{\circ}\right)\end{array}$ & $0.0 \%$ & $84.3 \%$ & $13.5 \%$ & $2.2 \%$ \\
\hline $24-48$ & $\begin{array}{l}2 \times \text { MAT } ; 4 \times \text { TRIAX; } \\
8 \times \text { C } 260\left(0^{\circ}\right) ; \\
14 \times \text { AS } / \mathrm{H} 3501\left(20^{\circ}\right)\end{array}$ & $38.9 \%$ & $22.2 \%$ & $33.3 \%$ & $5.6 \%$ \\
\hline $48-72$ & $\begin{array}{l}2 \times \mathrm{MAT} ; 4 \times \mathrm{TRIAX} \\
12 \times \mathrm{C} 260\left(0^{\circ}\right) ; \\
20 \times \mathrm{AS} / \mathrm{H} 3501\left(20^{\circ}\right)\end{array}$ & $43.5 \%$ & $26.1 \%$ & $26.1 \%$ & $4.3 \%$ \\
\hline $72-96$ & $\begin{array}{l}2 \times \text { MAT } ; 3 \times \text { TRIAX; } \\
16 \times \mathrm{C} 260\left(0^{\circ}\right) \\
26 \times \mathrm{AS} / \mathrm{H} 3501\left(20^{\circ}\right)\end{array}$ & $49.1 \%$ & $30.2 \%$ & $17.0 \%$ & $3.8 \%$ \\
\hline $96-120$ & $\begin{array}{l}2 \times \mathrm{MAT} ; 3 \times \text { TRIAX; } \\
14 \times \mathrm{C} 260\left(0^{\circ}\right) \\
23 \times \mathrm{AS} / \mathrm{H} 3501\left(20^{\circ}\right)\end{array}$ & $47.9 \%$ & $29.2 \%$ & $18.8 \%$ & $4.2 \%$ \\
\hline $120-144$ & $\begin{array}{l}2 \times \mathrm{MAT} ; 2 \times \text { TRIAX; } \\
11 \times \mathrm{C} 260\left(0^{\circ}\right) ; \\
19 \times \mathrm{AS} / \mathrm{H} 3501\left(20^{\circ}\right)\end{array}$ & $50.0 \%$ & $28.9 \%$ & $15.8 \%$ & $5.3 \%$ \\
\hline $144-168$ & $\begin{array}{l}2 \times \mathrm{MAT} ; 2 \times \text { TRIAX; } \\
11 \times \mathrm{C} 260\left(0^{\circ}\right) \\
18 \times \mathrm{AS} / \mathrm{H} 3501\left(20^{\circ}\right)\end{array}$ & $48.6 \%$ & $29.7 \%$ & $16.2 \%$ & $5.4 \%$ \\
\hline $168-192$ & $\begin{array}{l}2 \times \text { MAT } ; 2 \times \text { TRIAX; } \\
8 \times \text { C } 260\left(0^{\circ}\right) ; \\
14 \times \text { AS } / \mathrm{H} 3501\left(20^{\circ}\right)\end{array}$ & $46.7 \%$ & $26.7 \%$ & $20.0 \%$ & $6.7 \%$ \\
\hline $192-216$ & $\begin{array}{l}2 \times \mathrm{MAT} ; 2 \times \text { TRIAX; } \\
6 \times \mathrm{C} 260\left(0^{\circ}\right) \\
11 \times \mathrm{AS} / \mathrm{H} 3501\left(20^{\circ}\right)\end{array}$ & $44.0 \%$ & $24.0 \%$ & $24.0 \%$ & $8.0 \%$ \\
\hline $216-240$ & $\begin{array}{l}2 \times \text { MAT; } 2 \times \text { TRIAX; } \\
6 \times \text { C } 260\left(0^{\circ}\right) ; \\
10 \times \text { AS } / \mathrm{H} 3501\left(20^{\circ}\right)\end{array}$ & $41.7 \%$ & $25.0 \%$ & $25.0 \%$ & $8.3 \%$ \\
\hline $240-264$ & $\begin{array}{l}2 \times \mathrm{MAT} ; 2 \times \text { TRIAX; } \\
5 \times \mathrm{C} 260\left(0^{\circ}\right) ; \\
9 \times \mathrm{AS} / \mathrm{H} 3501\left(20^{\circ}\right)\end{array}$ & $40.9 \%$ & $22.7 \%$ & $27.3 \%$ & $9.1 \%$ \\
\hline $264-288$ & $\begin{array}{l}2 \times \text { MAT; } 2 \times \text { TRIAX; } \\
5 \times \text { C } 260\left(0^{\circ}\right) ; \\
8 \times \text { AS/H3501 }\left(20^{\circ}\right)\end{array}$ & $38.1 \%$ & $23.8 \%$ & $28.6 \%$ & $9.5 \%$ \\
\hline $288-312$ & 2 x MAT; 6 x TRIAX & $0.0 \%$ & $0.0 \%$ & $90.0 \%$ & $10.0 \%$ \\
\hline Spar & $4 \times$ TRIAX & $0.0 \%$ & $0.0 \%$ & $90.0 \%$ & $10.0 \%$ \\
\hline
\end{tabular}

*: The first number is the number of layers (i.e. $2 \times$ MAT means 2 layers of MAT material). 
Table 3.11 Laminate Lay-up for SERI-8 Enhanced Model (with bend-twist-coupling) with $100 \%$ Unidirectional Glass Replacement

\begin{tabular}{|c|c|c|c|c|c|}
\hline Station & Laminate Lay-up ${ }^{*}$ & $\begin{array}{c}\text { Volume } \\
\text { Fraction of } \\
\text { AS/H3501 }\end{array}$ & $\begin{array}{c}\text { Volume } \\
\text { Fraction of } \\
\text { C260 Material }\end{array}$ & $\begin{array}{l}\text { Volume } \\
\text { Fraction of } \\
\text { TRIAX }\end{array}$ & $\begin{array}{l}\text { Volume } \\
\text { Fraction of } \\
\text { MAT }\end{array}$ \\
\hline $0-24$ & $\begin{array}{l}2 \times \text { MAT } ; 4 \text { x TRIAX; } \\
75 \times \text { C } 260\left(90^{\circ}\right)\end{array}$ & $0.0 \%$ & $84.3 \%$ & $13.5 \%$ & $2.2 \%$ \\
\hline $24-48$ & $\begin{array}{l}2 \times \text { MAT; } 4 \times \text { TRIAX; } \\
18 \times \text { AS/H3501 }\left(20^{\circ}\right)\end{array}$ & $56.3 \%$ & $0.0 \%$ & $37.5 \%$ & $6.3 \%$ \\
\hline $48-72$ & $\begin{array}{l}2 \times \text { MAT } ; 4 \times \text { TRIAX; } \\
26 \times \text { AS/H3501 }\left(20^{\circ}\right)\end{array}$ & $65.0 \%$ & $0.0 \%$ & $30.0 \%$ & $5.0 \%$ \\
\hline $72-96$ & $\begin{array}{l}2 \times \text { MAT } ; 3 \times \text { TRIAX; } \\
33 \times \text { AS/H3501 }\left(20^{\circ}\right)\end{array}$ & $75.0 \%$ & $0.0 \%$ & $20.5 \%$ & $4.5 \%$ \\
\hline $96-120$ & $\begin{array}{l}2 \times \text { MAT; } 3 \times \text { TRIAX; } \\
29 \times \text { AS } / H 3501\left(20^{\circ}\right)\end{array}$ & $72.5 \%$ & $0.0 \%$ & $22.5 \%$ & $5.0 \%$ \\
\hline $120-144$ & $\begin{array}{l}2 \times \text { MAT; } 2 \times \text { TRIAX; } \\
23 \times \text { AS/H3501 }\left(20^{\circ}\right)\end{array}$ & $74.2 \%$ & $0.0 \%$ & $19.4 \%$ & $6.5 \%$ \\
\hline $144-168$ & $\begin{array}{l}2 \times \text { MAT } ; 2 \times \text { TRIAX; } \\
23 \times \text { AS } / \mathrm{H} 3501\left(20^{\circ}\right)\end{array}$ & $74.2 \%$ & $0.0 \%$ & $19.4 \%$ & $6.5 \%$ \\
\hline $168-192$ & $\begin{array}{l}2 \times \text { MAT } ; 2 \times \text { TRIAX; } \\
18 \times \text { AS } / \mathrm{H} 3501\left(20^{\circ}\right)\end{array}$ & $69.2 \%$ & $0.0 \%$ & $23.1 \%$ & $7.7 \%$ \\
\hline $192-216$ & $\begin{array}{l}2 \times \text { MAT; } 2 \times \text { TRIAX; } \\
13 \times \text { AS/H3501 }\left(20^{\circ}\right)\end{array}$ & $61.9 \%$ & $0.0 \%$ & $28.6 \%$ & $9.5 \%$ \\
\hline $216-240$ & $\begin{array}{l}2 \times \text { MAT; } 2 \times \text { TRIAX; } \\
13 \times \text { AS/H3501 }\left(20^{\circ}\right)\end{array}$ & $61.9 \%$ & $0.0 \%$ & $28.6 \%$ & $9.5 \%$ \\
\hline $240-264$ & $\begin{array}{l}2 \times \text { MAT; } 2 \times \text { TRIAX; } \\
11 \times \text { AS } / \mathrm{H} 3501\left(20^{\circ}\right)\end{array}$ & $57.9 \%$ & $0.0 \%$ & $31.6 \%$ & $10.5 \%$ \\
\hline $264-288$ & $\begin{array}{l}2 \times \mathrm{MAT} ; 2 \times \text { TRIAX; } \\
10 \times \mathrm{AS} / \mathrm{H} 3501\left(20^{\circ}\right)\end{array}$ & $55.6 \%$ & $0.0 \%$ & $33.3 \%$ & $11.1 \%$ \\
\hline $288-312$ & $2 \times$ MAT; $6 \times$ TRIAX & $0.0 \%$ & $0.0 \%$ & $90.0 \%$ & $10.0 \%$ \\
\hline Spar & $4 \mathrm{x}$ TRIAX & $0.0 \%$ & $0.0 \%$ & $90.0 \%$ & $10.0 \%$ \\
\hline
\end{tabular}

*: The first number is the number of layers (i.e. $2 \times$ MAT means 2 layers of MAT material). 


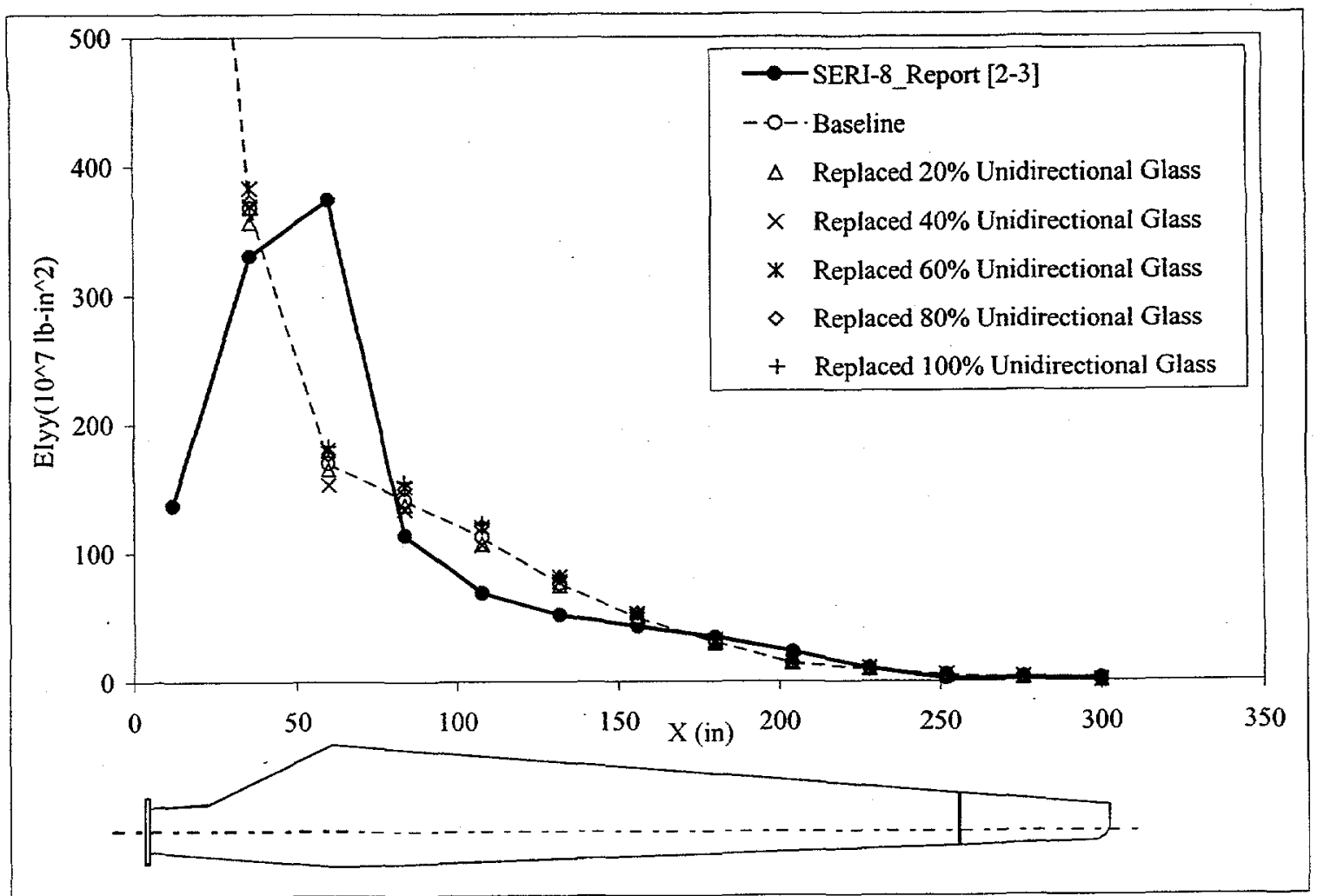

Figure 3.1 Enhanced Models Having the Same $\mathrm{EI}_{\mathrm{yy}}$ Distribution

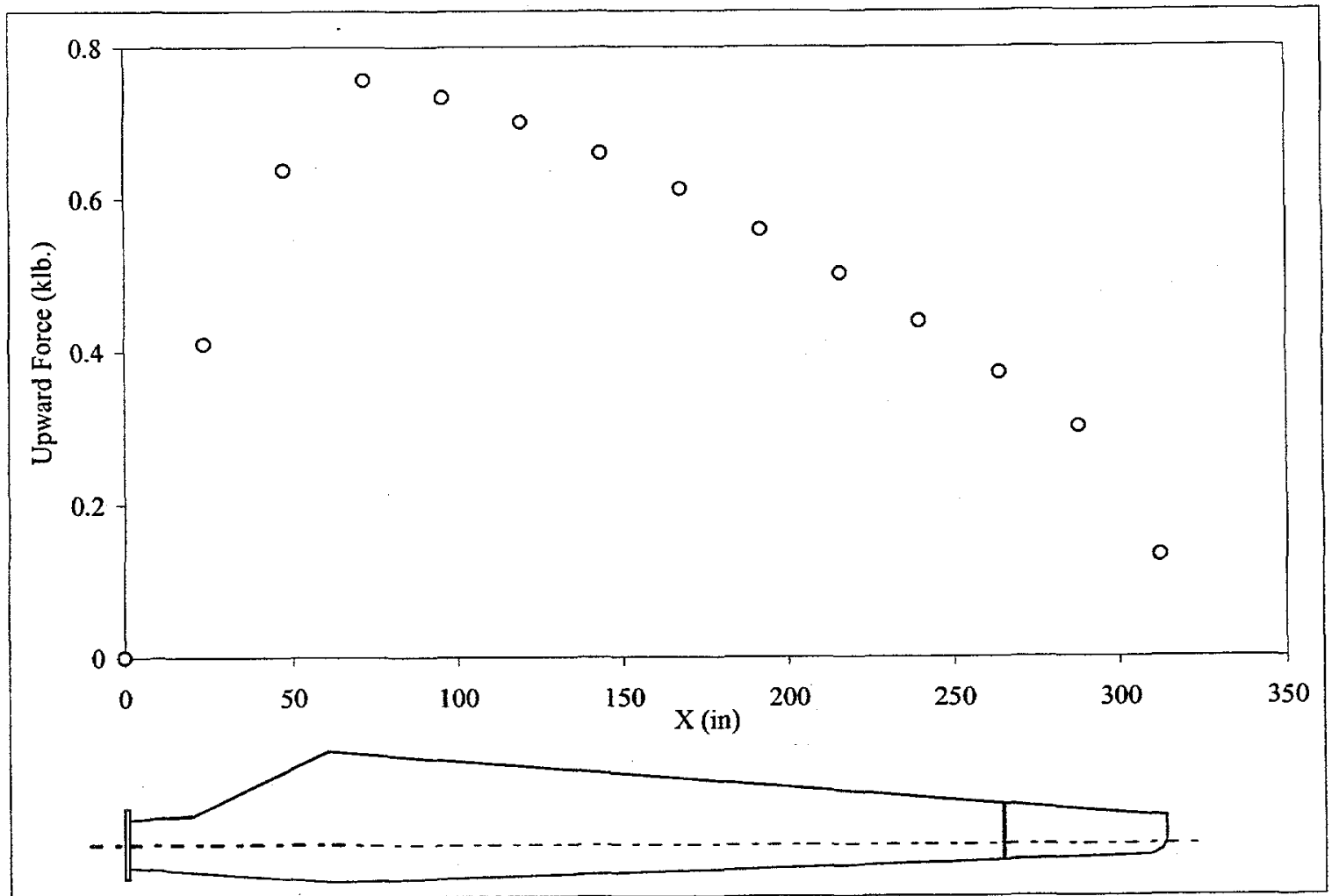

Figure 3.2 Nodal Force Distribution Input for 3D_Beam Code 


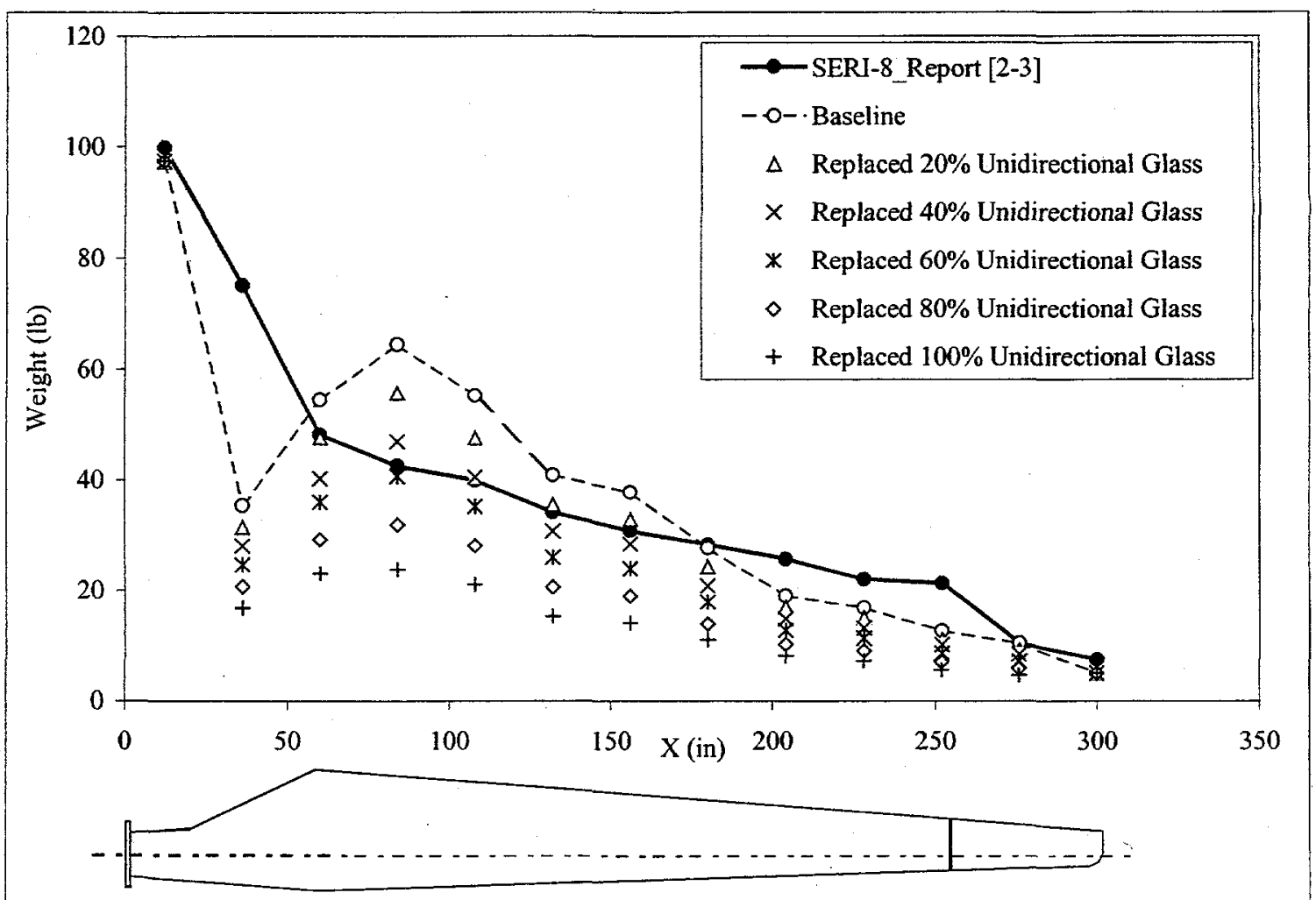

Figure 3.3 Weight Distribution for Various Configurations

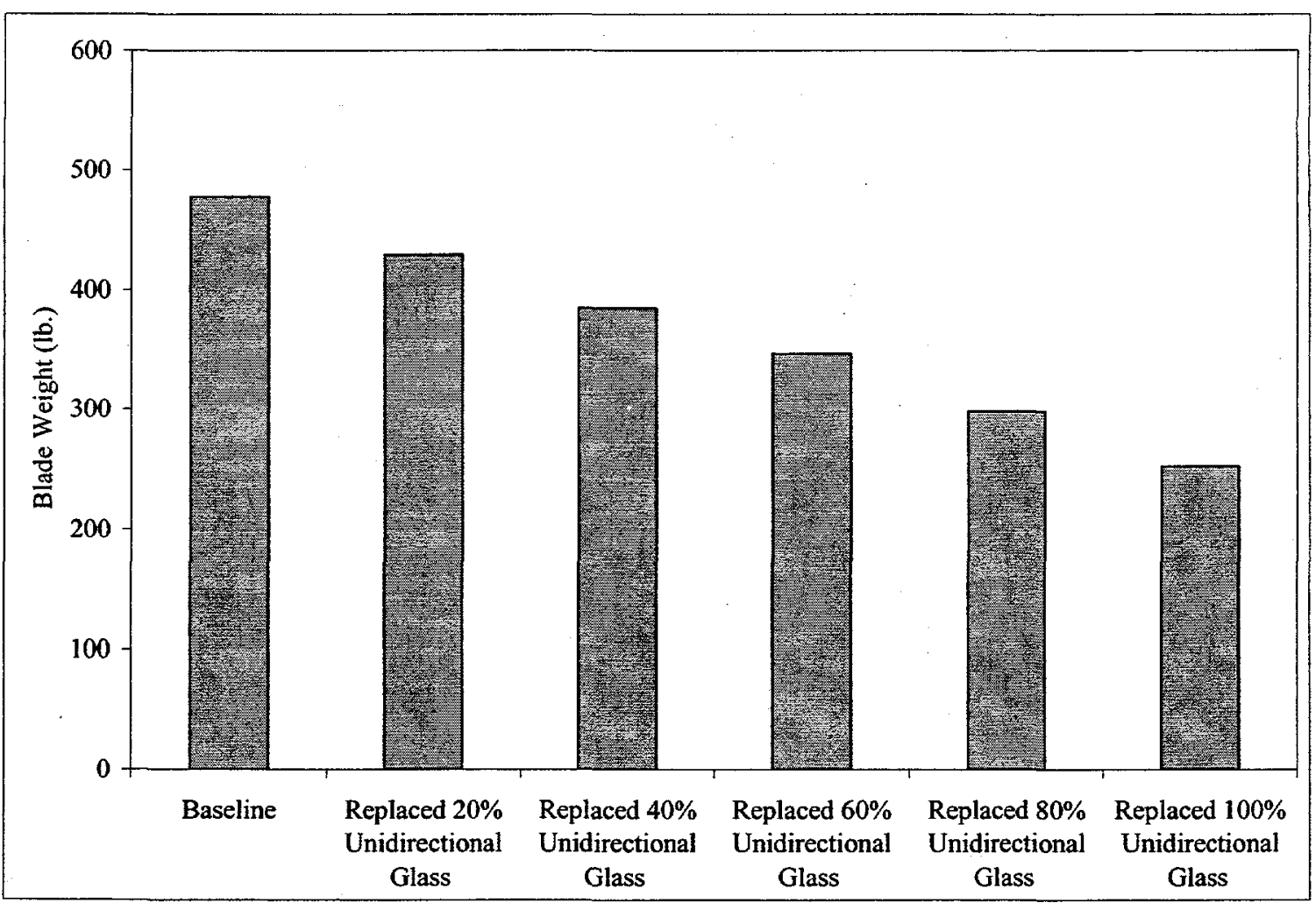

Figure 3.4 Reduction in Total Blade Weight as More Carbon Fibers are used 


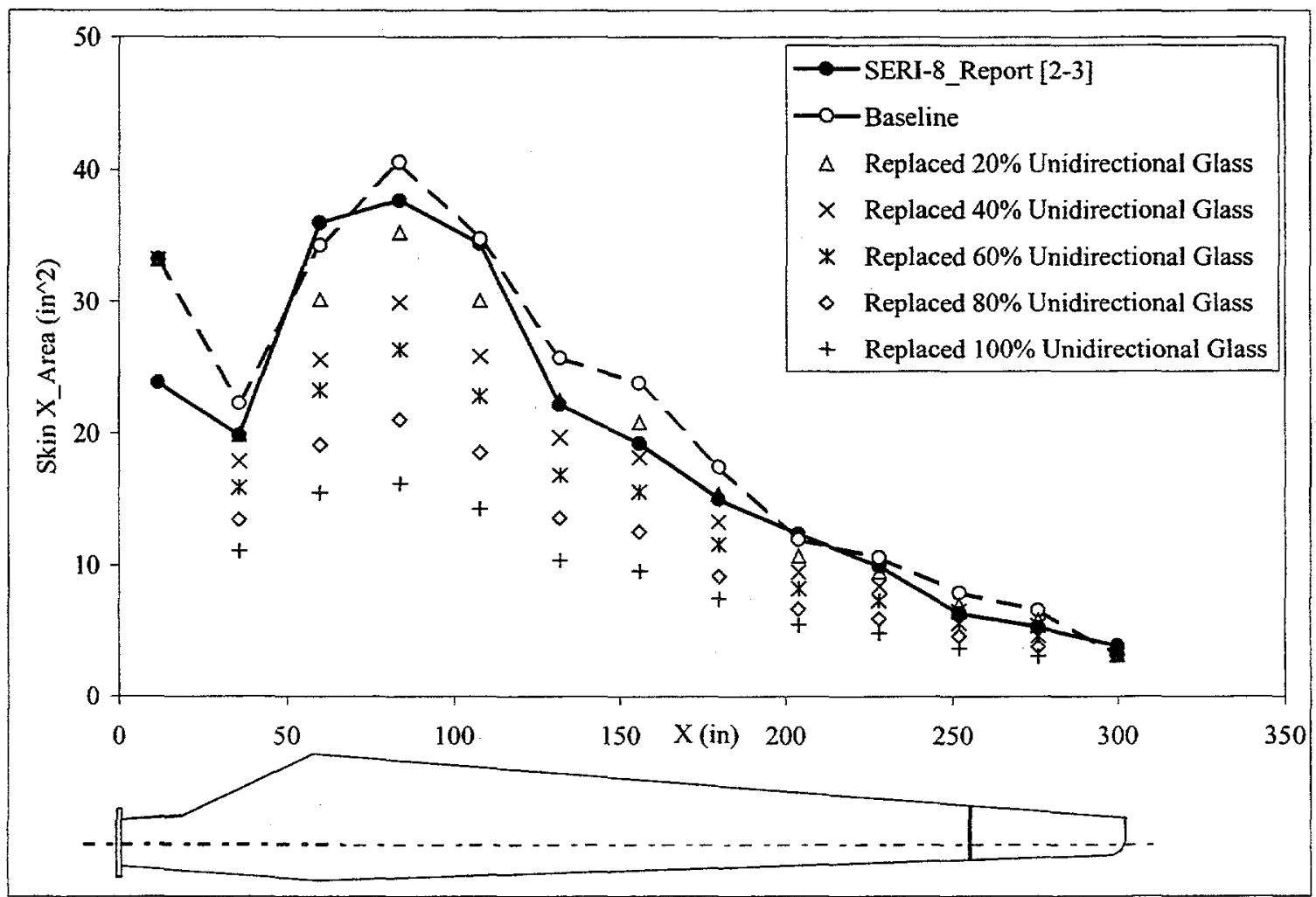

Figure 3.5 Skin Cross-section Area Distribution for Various Configurations

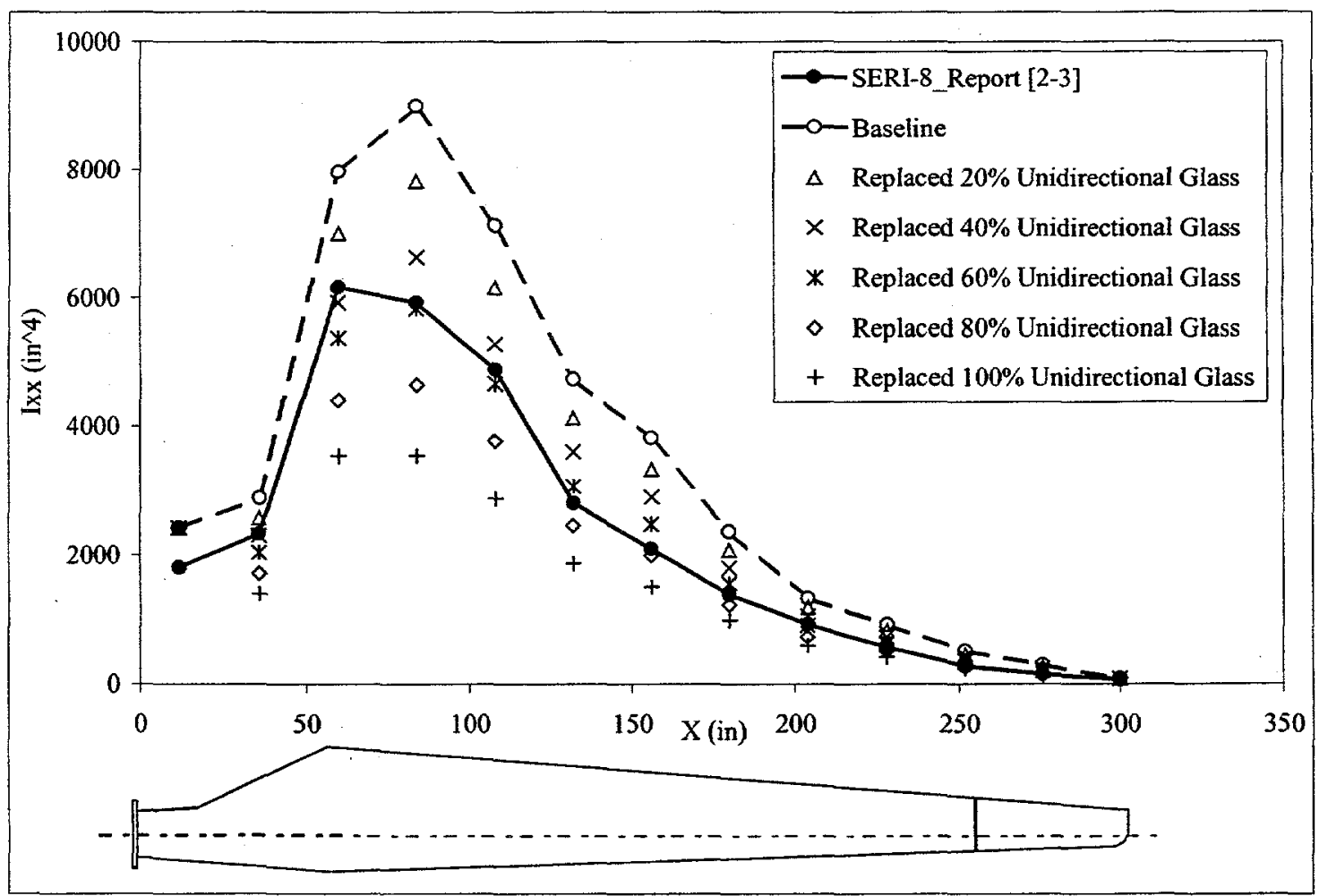

Figure 3.6 $\quad I_{x x}$ Distribution for Various Configurations 


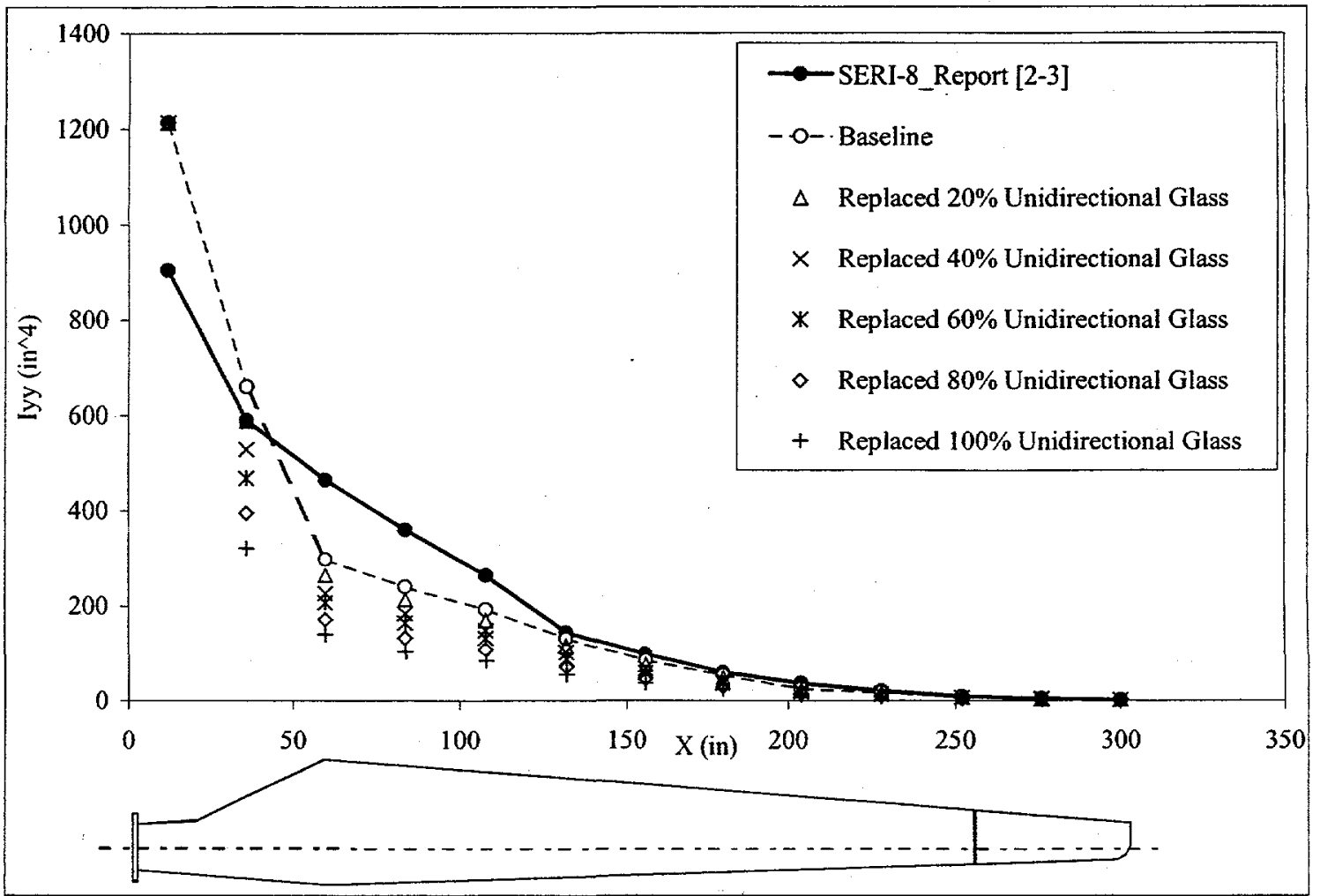

Figure 3.7 $I_{y y}$ Distribution for Various Configurations

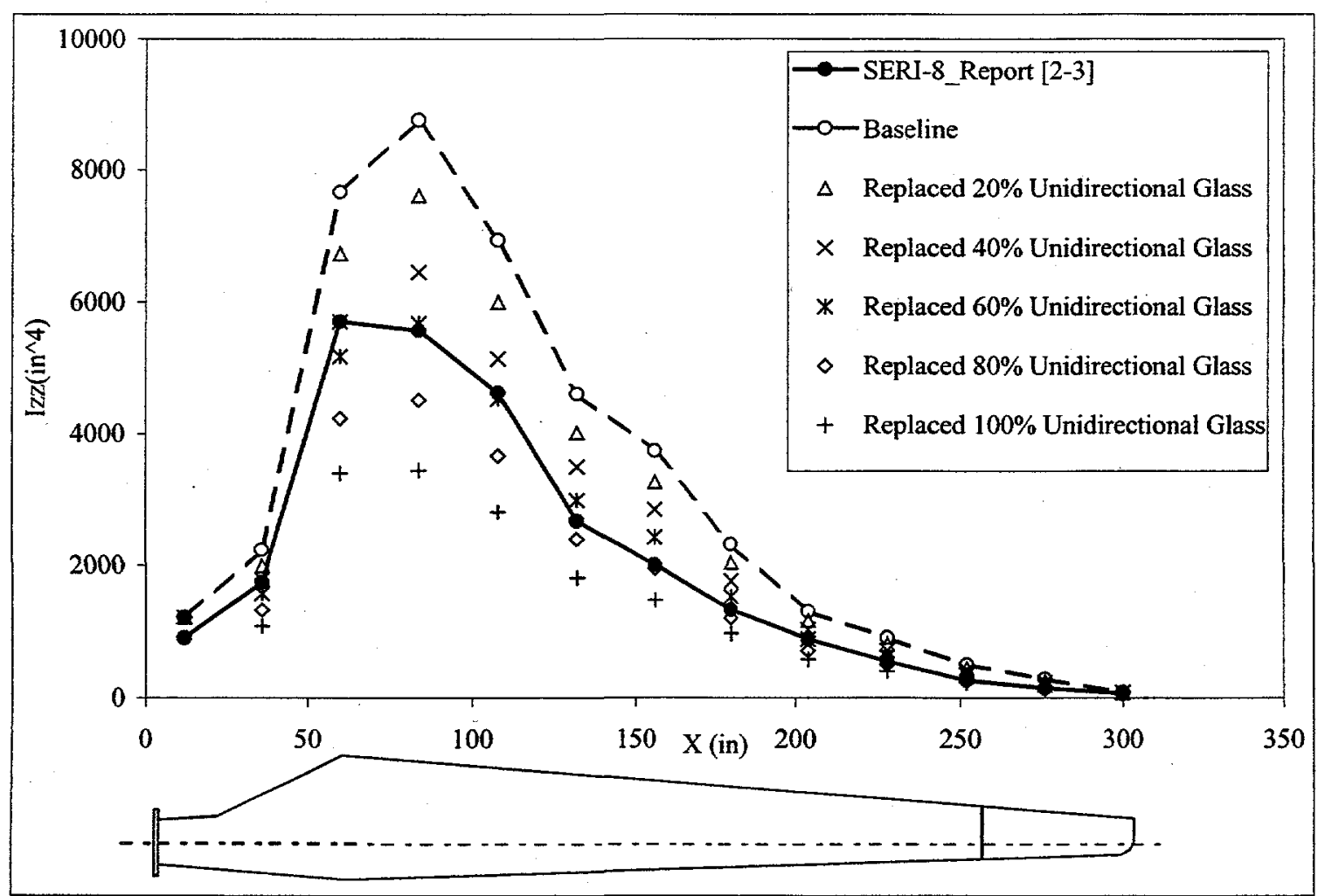

Figure $3.8 \quad I_{\mathrm{zz}}$ Distribution for Various Configurations 


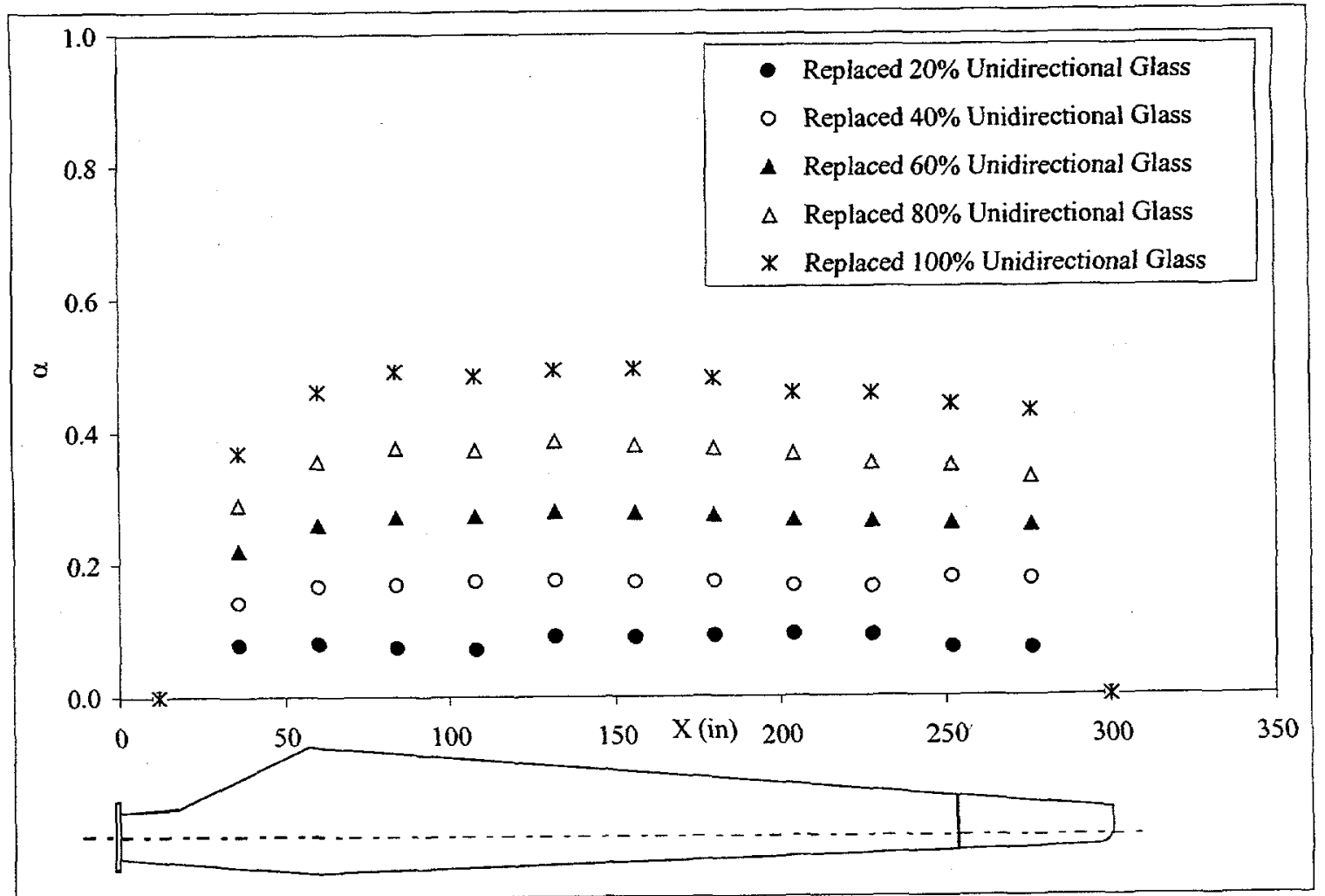

Figure 3.9 $\alpha$ Distribution for Various Configurations with Bend-Twist Coupling 


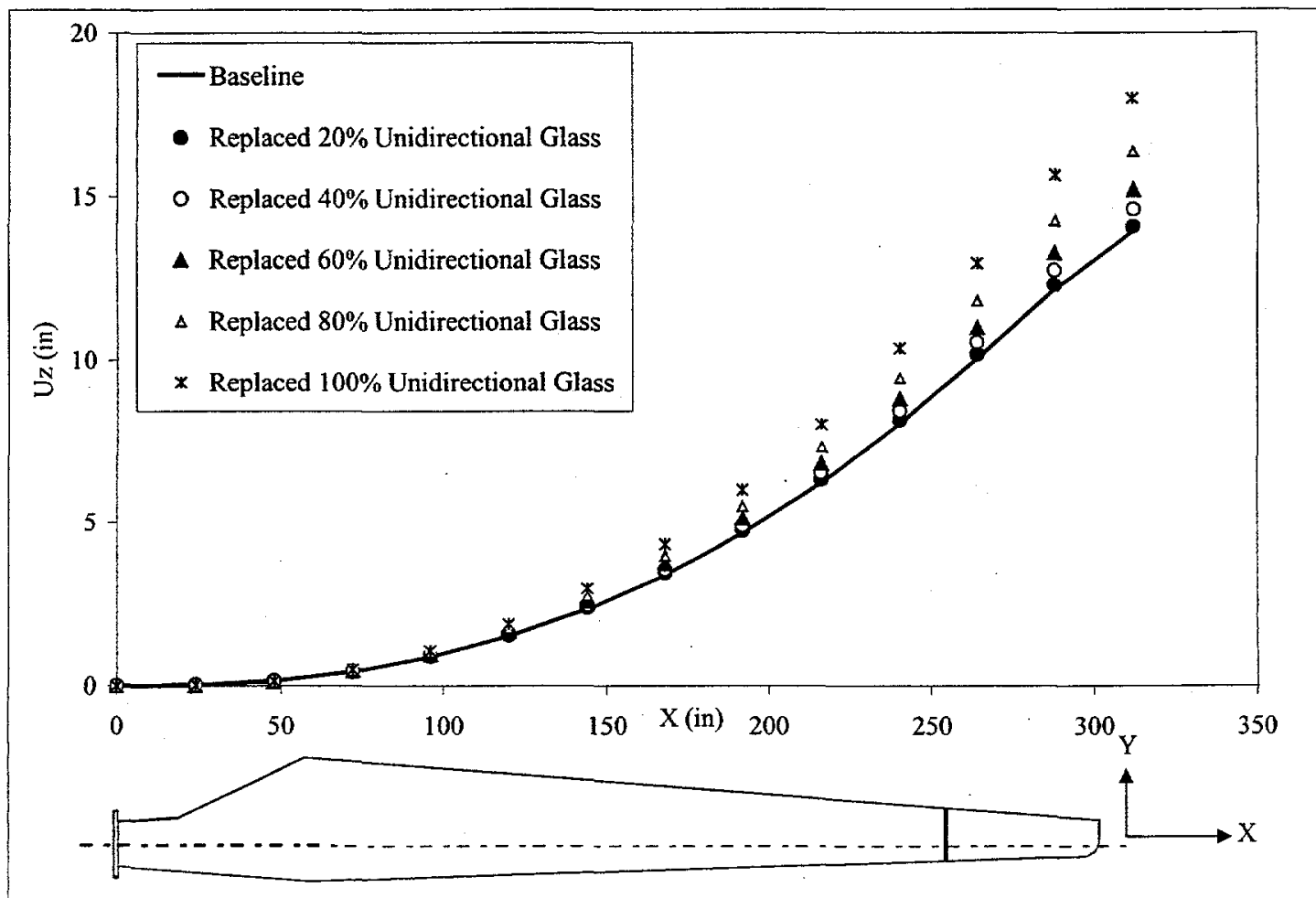

Figure 3.10 Vertical Deflection along the Blade for Various Configurations with Bend-Twist Coupling. Wind Load is $70 \mathrm{~m} / \mathrm{s}$ and $C_{d}$ is 1.7 .

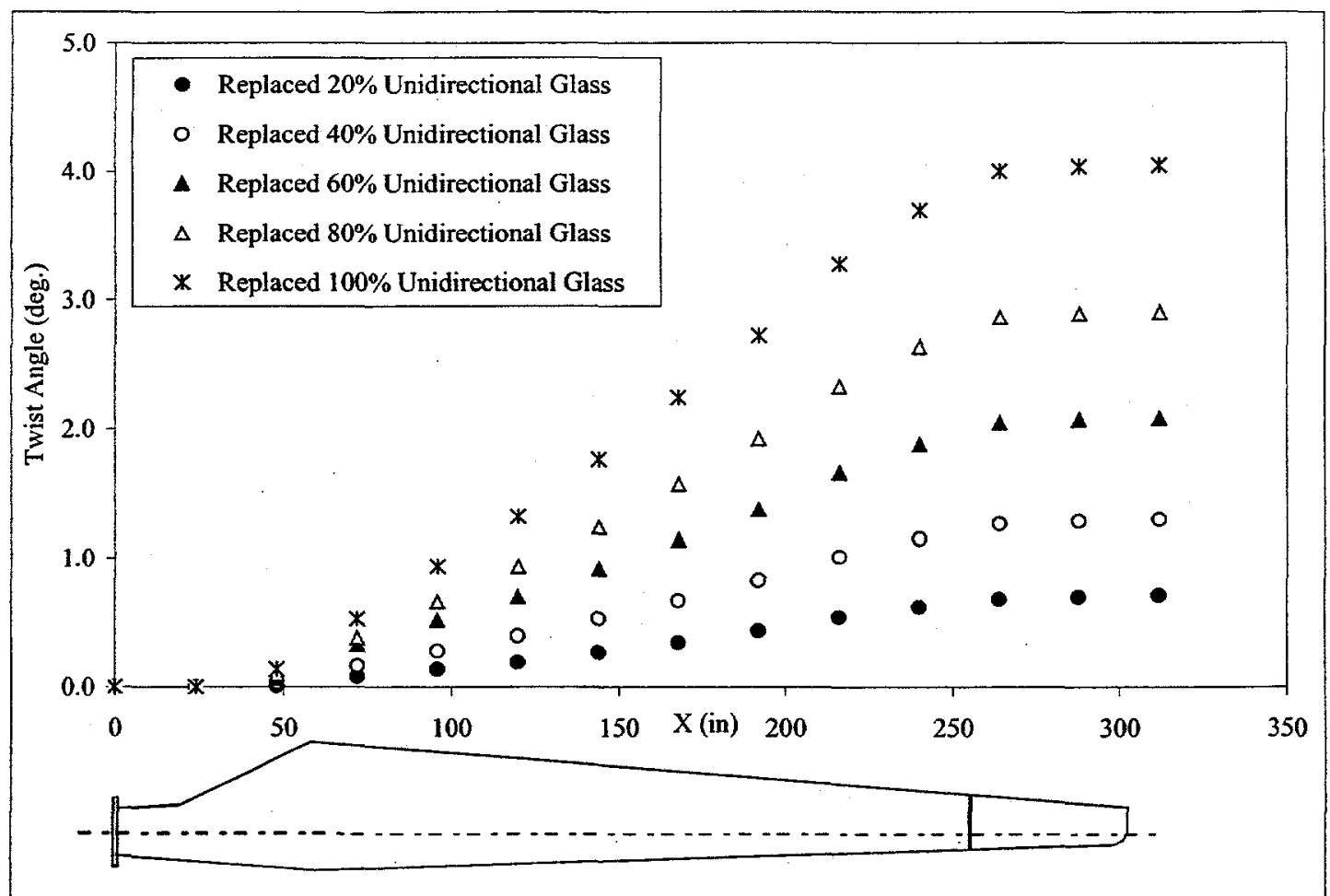

Figure 3.11 Bend-induced Twist along the Blade for Various Configurations with Bend-Twist Coupling. Wind Load is $70 \mathrm{~m} / \mathrm{s}$ and $C_{d}$ is 1.7 . 


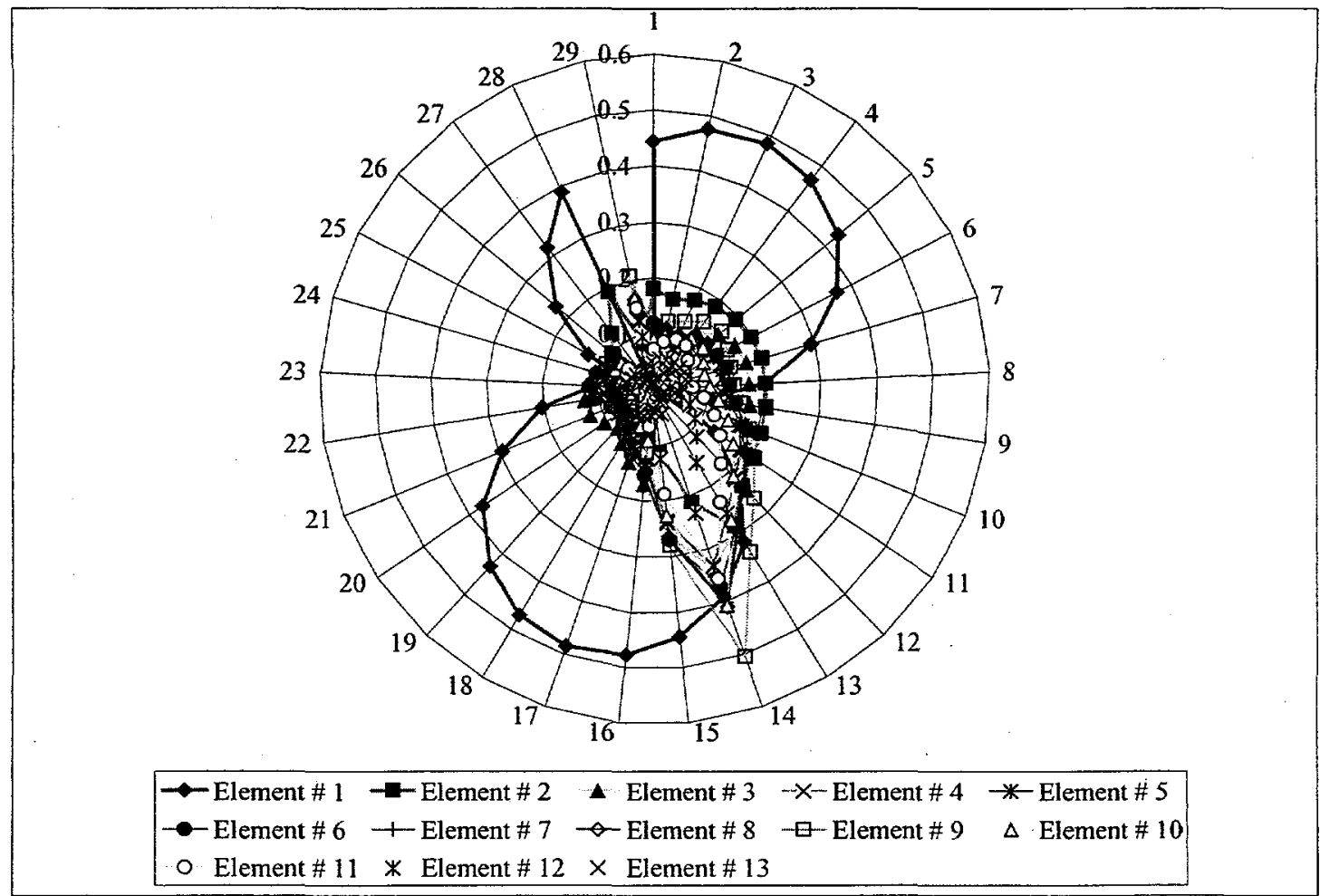

Figure 3.12 Failure Index along the "Brick Elements" for the Respective Blade Element (Baseline Configuration)

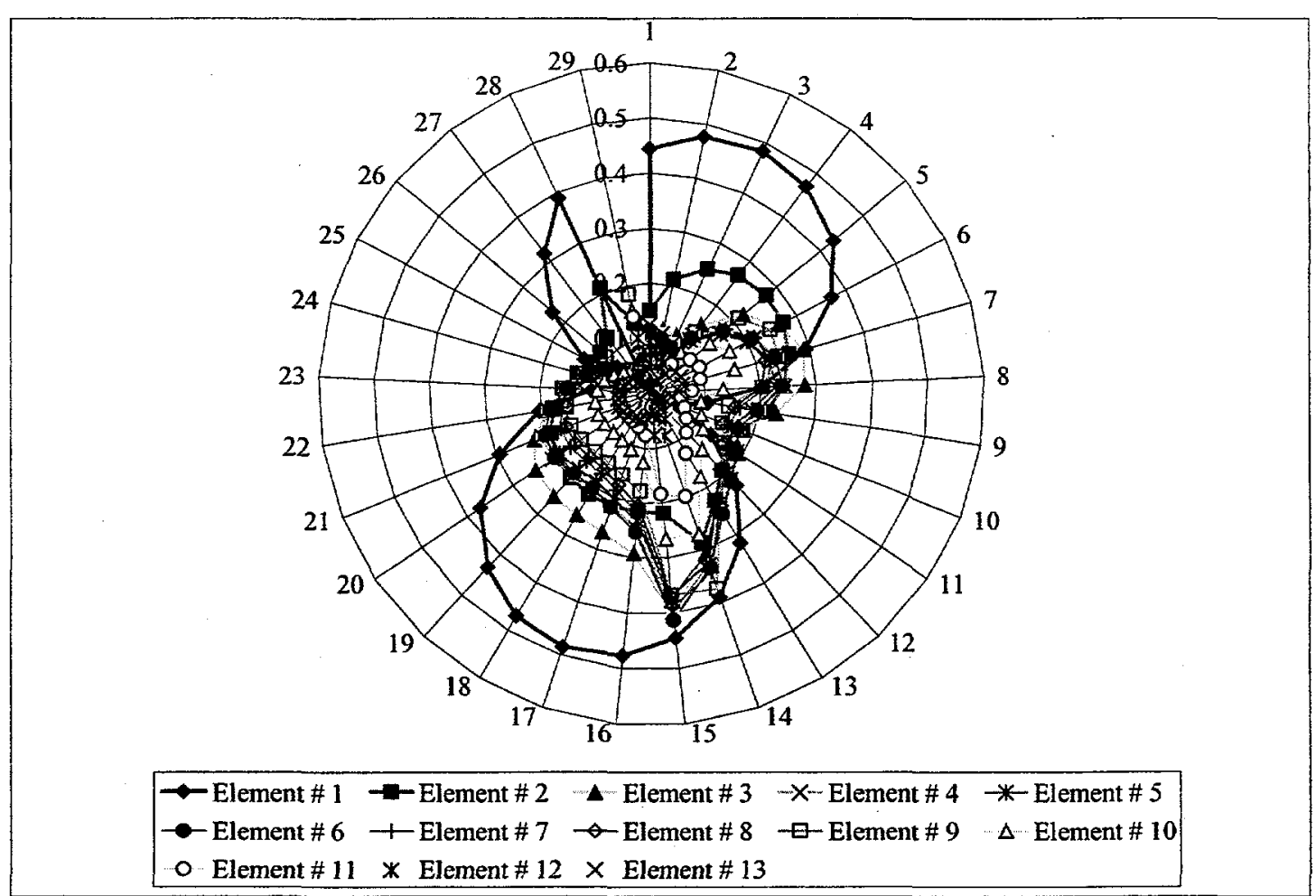

Figure 3.13 Failure Index along the "Brick Elements" for the Respective Blade Element (Twist-to-Feather; 100\% Unidirectional Glass Replacement) 


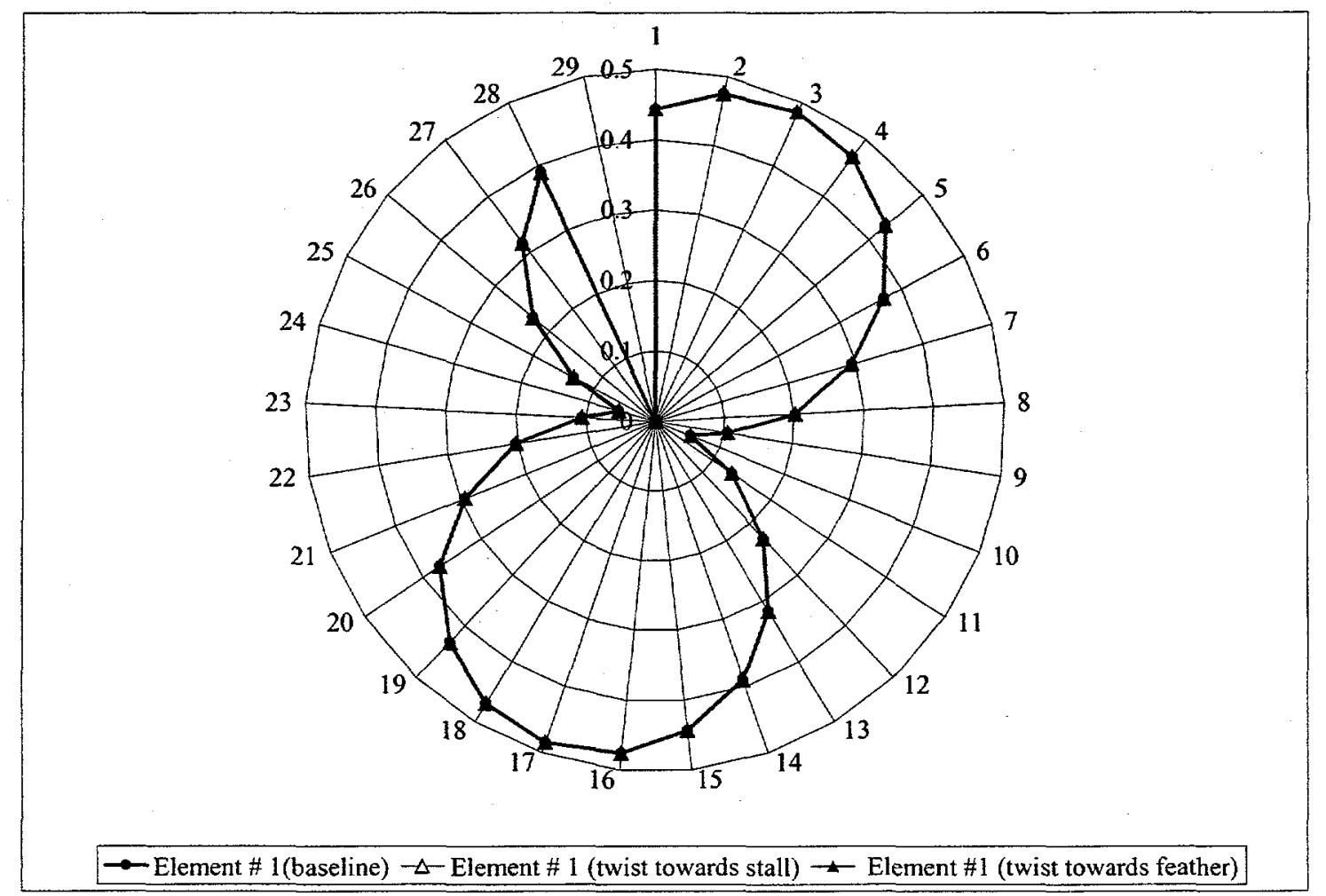

$-10$

$-5$

0

5

10

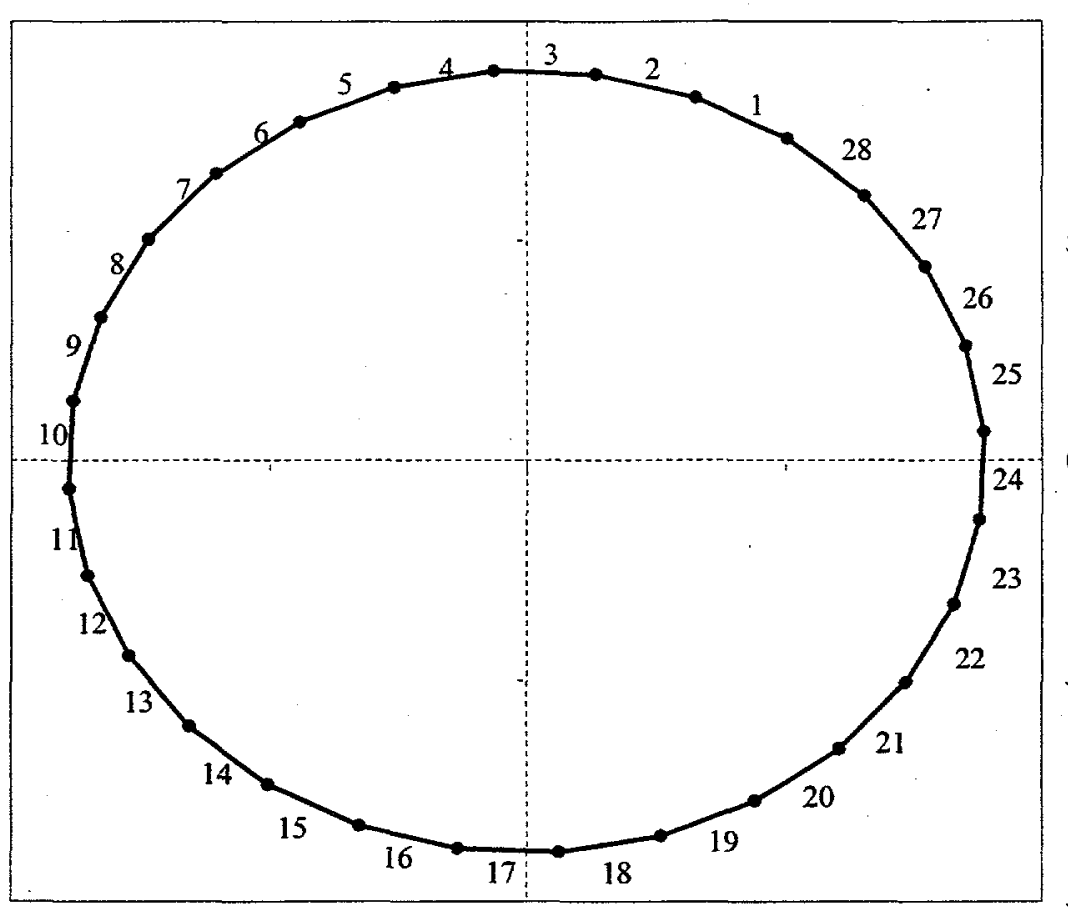

10

5

10

Figure 3.14 Top:

Failure Index along the "Brick Elements" for Blade Element No. 1 (Station 0 - 24) for the Baseline Configuration and Configuration with $100 \%$ Unidirectional Glass Replacement (Wind Load is $70 \mathrm{~m} / \mathrm{s} ; C_{d}$ is 1.7 ).

Bottom: Brick Element Numbering for Blade Element No. 1. 


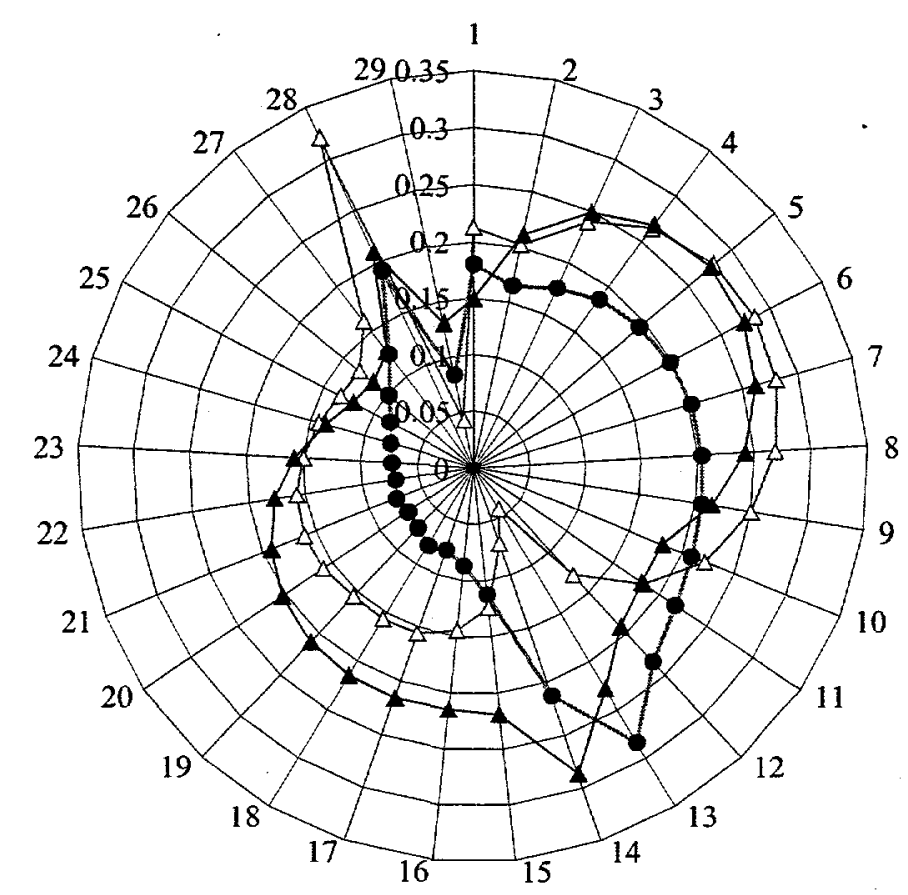

- Element \# 2 (baseline) $\triangle-$ Element \# 2 (twist towards stall) $\rightarrow-$ Element \#2 (twist towards feather)

$\begin{array}{lllllll}-10 & -5 & 0 & 5 & 10 & 15 & 20\end{array}$

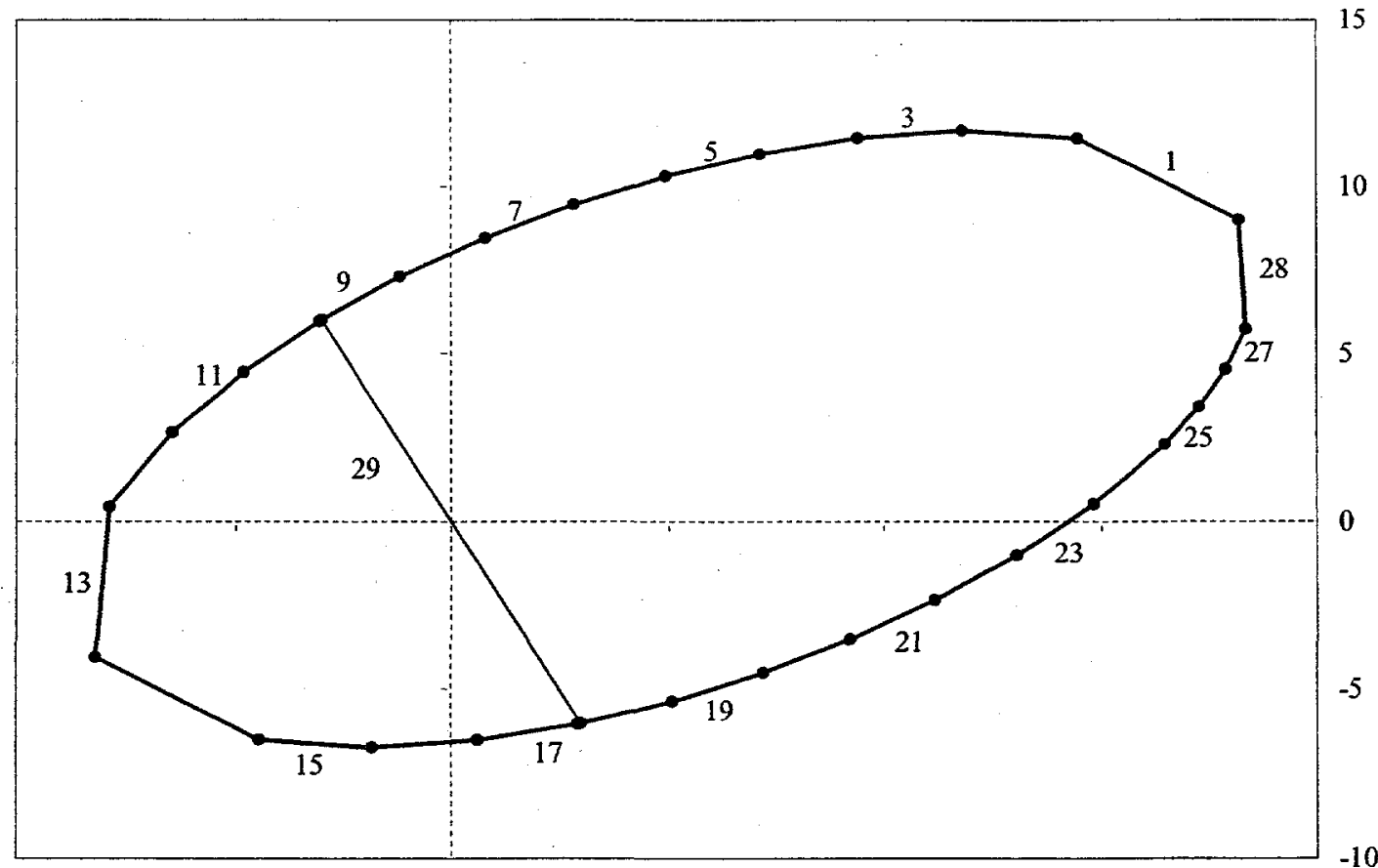

Figure 3.15 Top:

Failure Index along the "Brick Elements" for Blade Element No. 2 (Station 24 - 48) for the Baseline Configuration and Configuration with $100 \%$ Unidirectional Glass Replacement (Wind Load is $70 \mathrm{~m} / \mathrm{s} ; \mathrm{C}_{\mathrm{d}}$ is 1.7 ).

Bottom: $\quad$ Brick Element Numbering for Blade Element No. 2. 

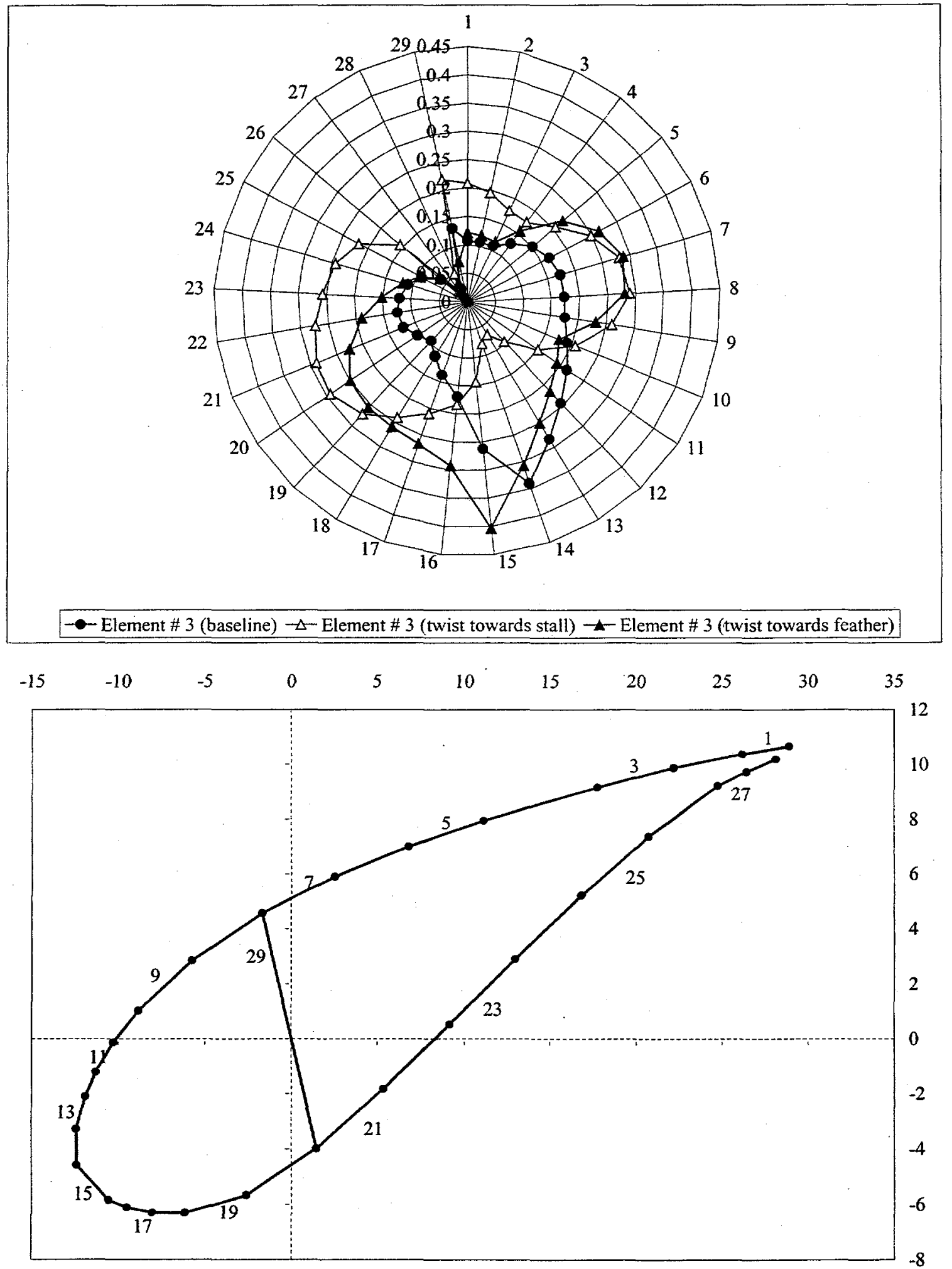

Figure 3.16 Top: Failure Index along the "Brick Elements" for Blade Element No. 3 (Station 48 - 72) for the Baseline Configuration and Configuration with $100 \%$ Unidirectional Glass Replacement (Wind Load is $70 \mathrm{~m} / \mathrm{s} ; \mathrm{C}_{\mathrm{d}}$ is 1.7 ).

Bottom: Brick Element Numbering for Blade Element No. 3. 


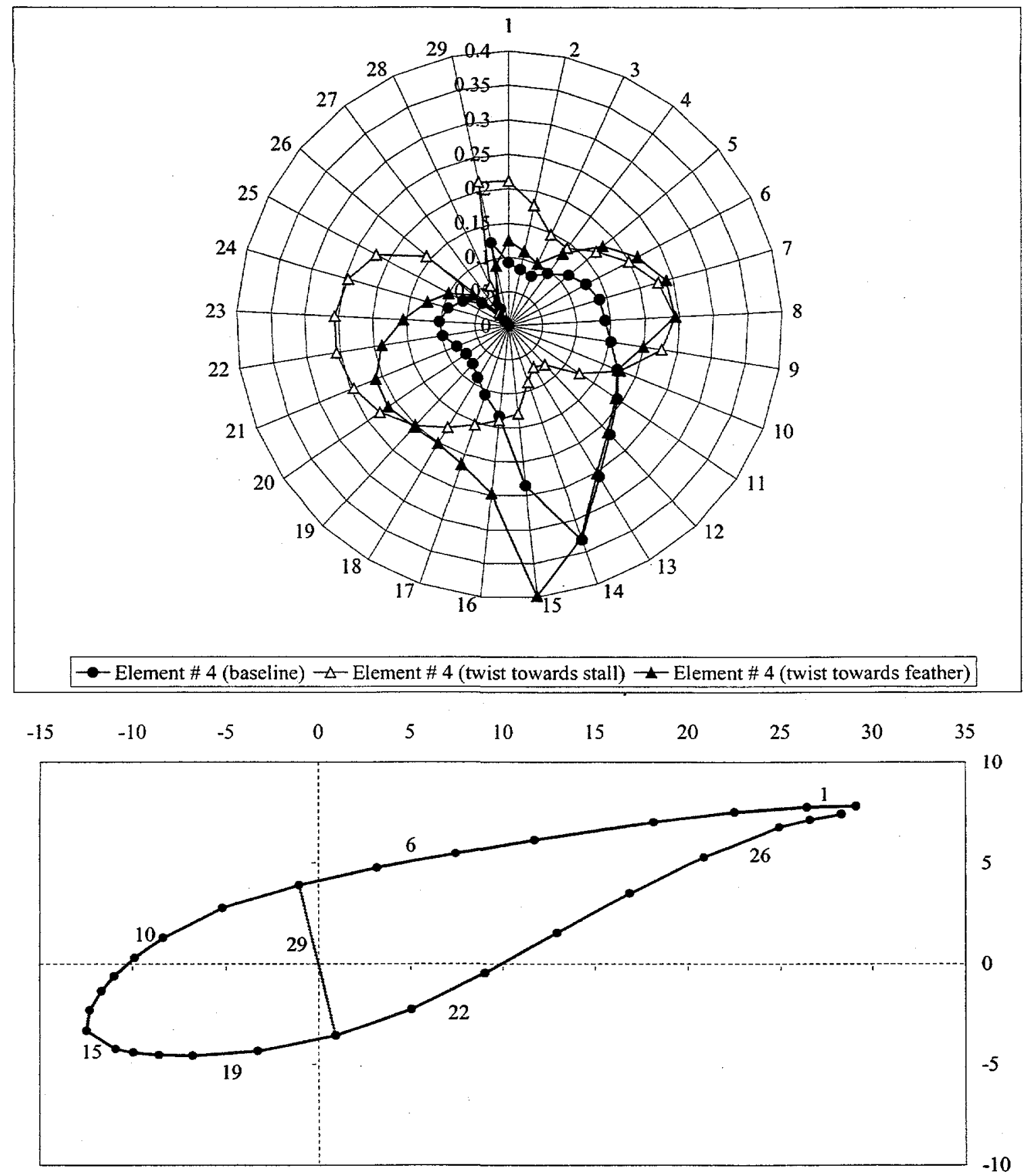

Figure 3.17 Top: Failure Index along the "Brick Elements" for Blade Element No. 4 (Station 72 - 96) for the Baseline Configuration and Configuration with $100 \%$ Unidirectional Glass Replacement (Wind Load is $70 \mathrm{~m} / \mathrm{s} ; \mathrm{C}_{\mathrm{d}}$ is 1.7 ).

Bottom: Brick Element Numbering for Blade Element No. 4. 

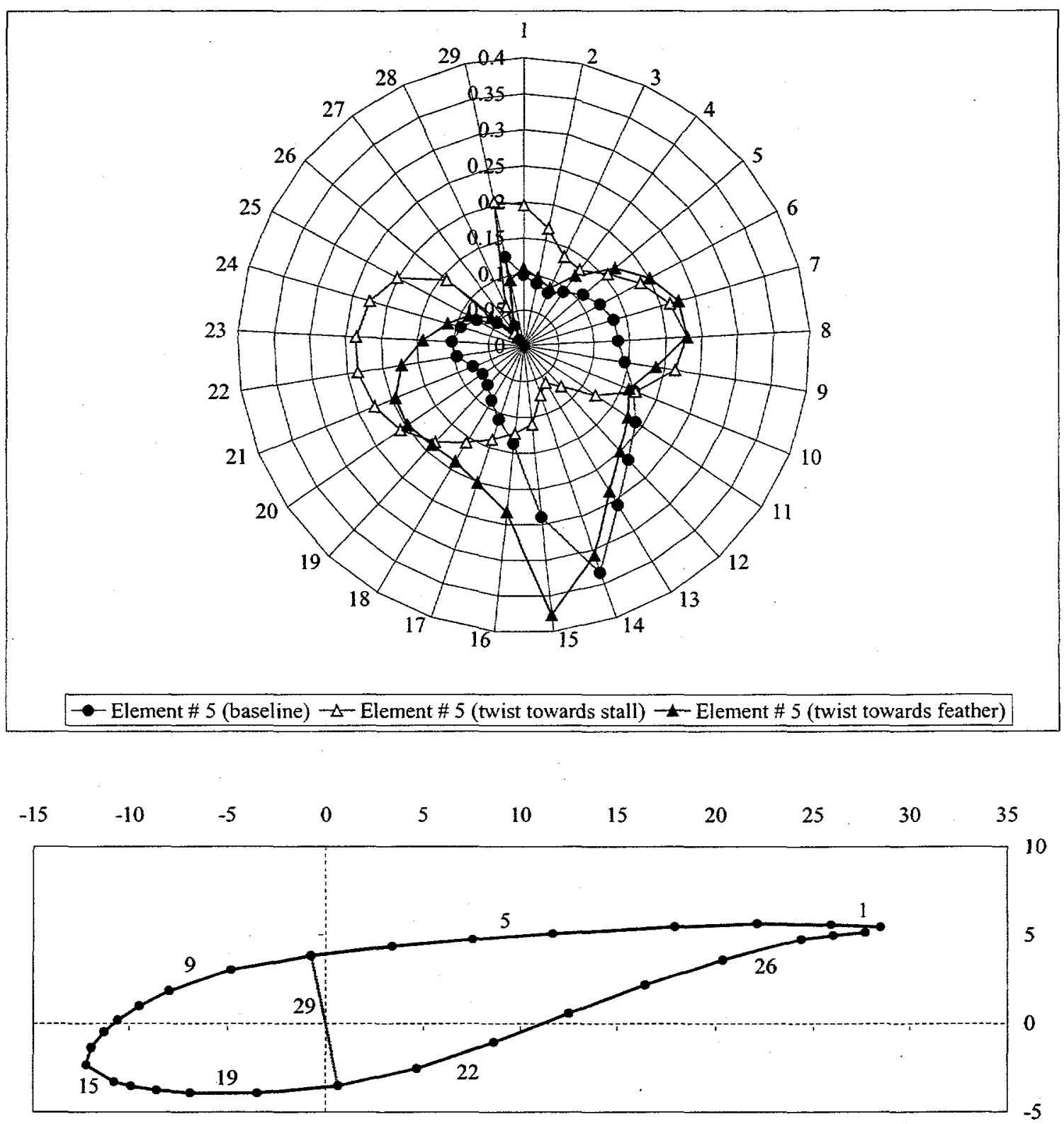

Figure 3.18 Top: Failure Index along the "Brick Elements" for Blade Element No. 5 (Station 96 - 120) for the Baseline Configuration and Configuration with $100 \%$ Unidirectional Glass Replacement (Wind Load is $70 \mathrm{~m} / \mathrm{s} ; \mathrm{C}_{\mathrm{d}}$ is 1.7 ).

Bottom: Brick Element Numbering for Blade Element No. 5. 

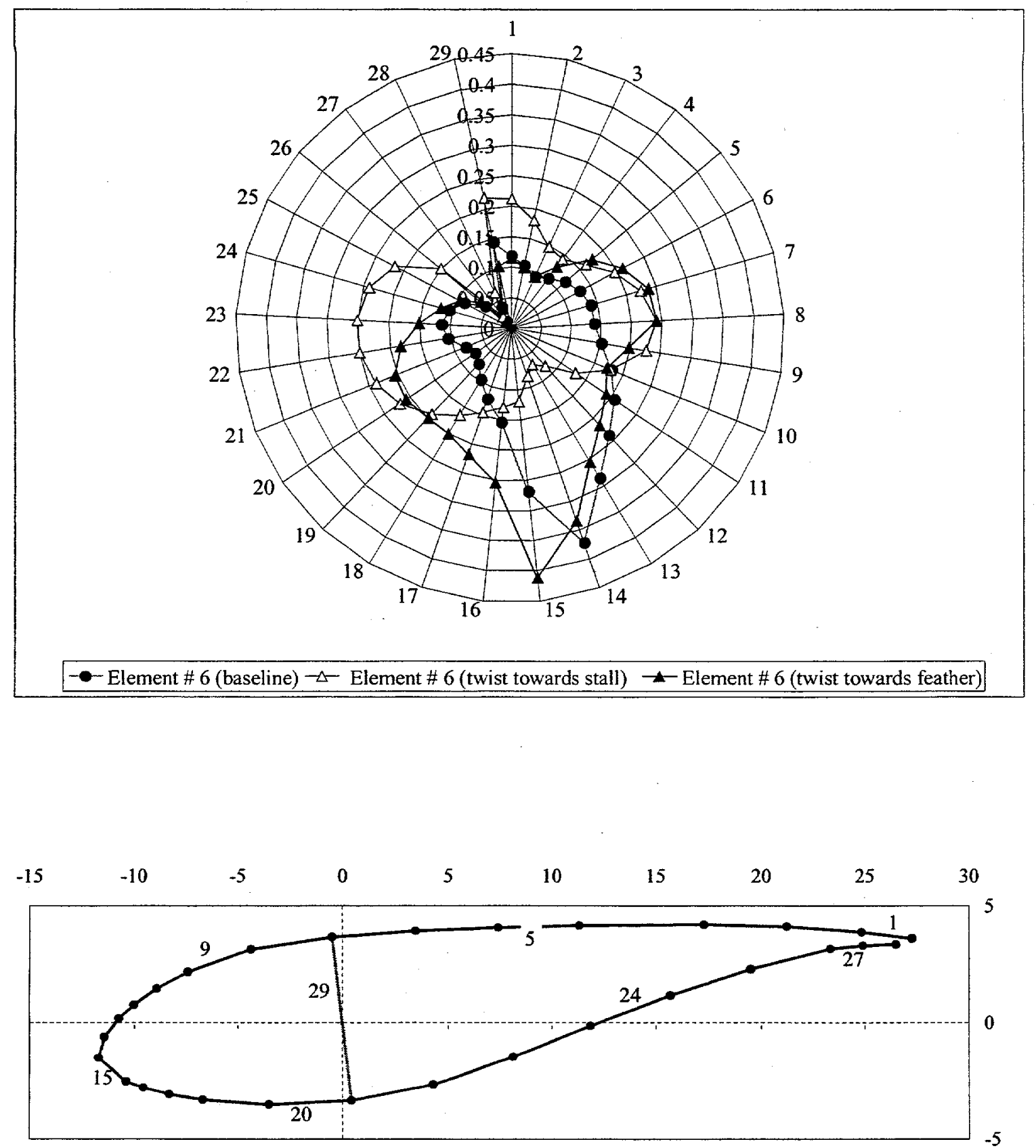

Figure 3.19 Top: Failure Index along the "Brick Elements" for Blade Element No. 6 (Station 120 - 144) for the Baseline Configuration and Configuration with $100 \%$ Unidirectional Glass Replacement (Wind Load is $70 \mathrm{~m} / \mathrm{s} ; \mathrm{C}_{\mathrm{d}}$ is 1.7 ).

Bottom: Brick Element Numbering for Blade Element No. 6. 


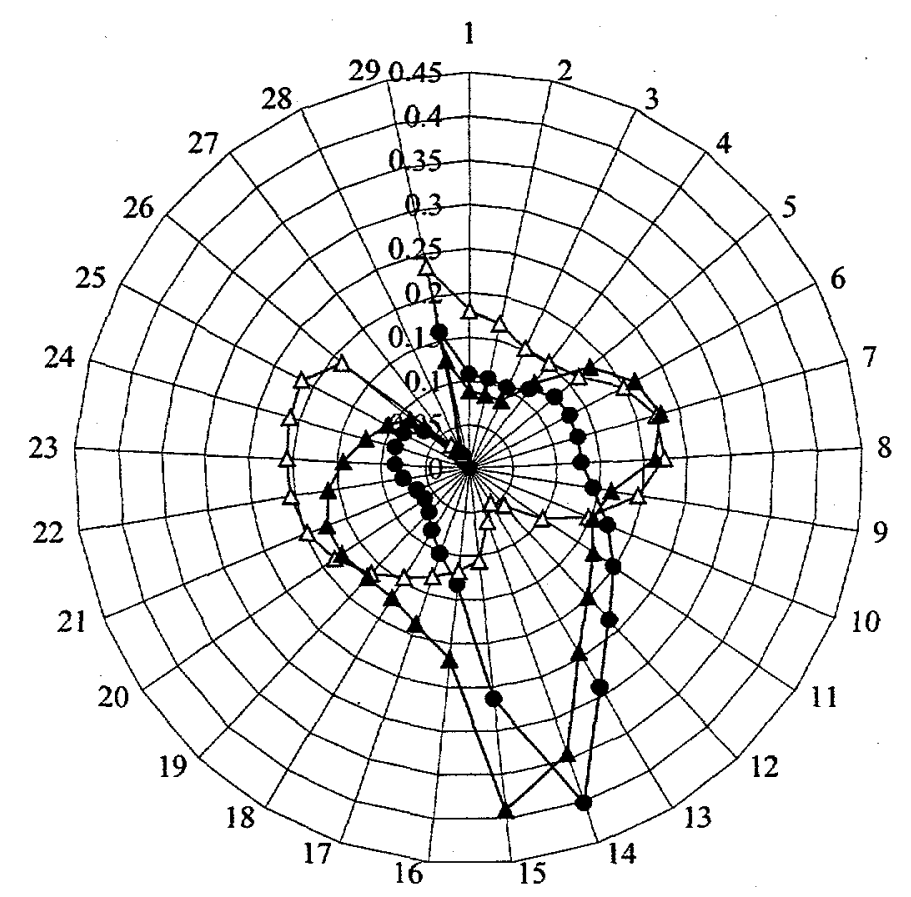

$\rightarrow$ Element \# 7 (baseline) $-\Delta$-Element \# 7 (twist towards stall) $-\downarrow$ Element \# 7 (twist towards feather)

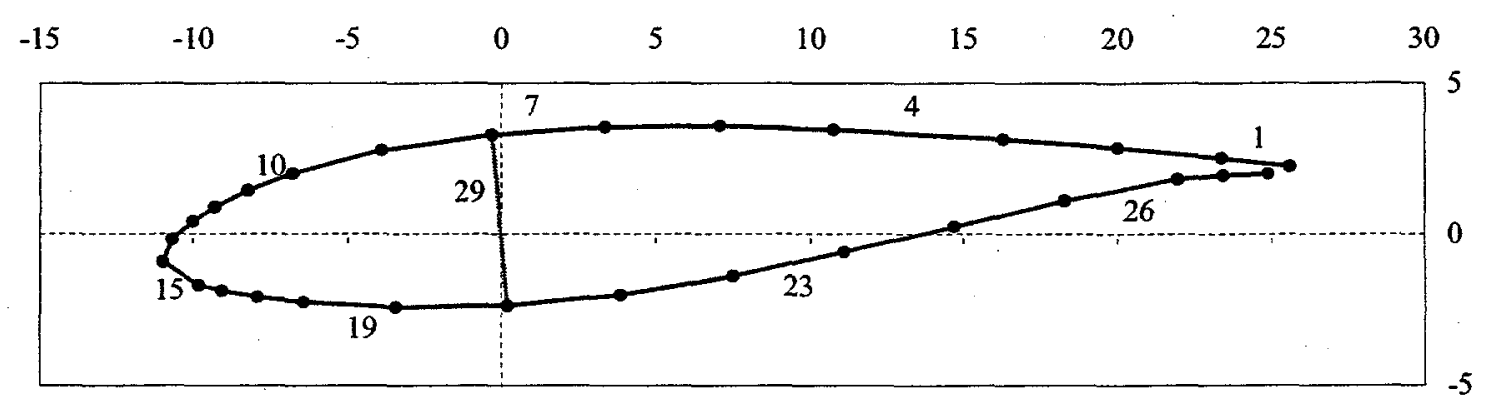

Figure 3.20 Top: Failure Index along the "Brick Elements" for Blade Element No. 7 (Station 144 - 168) for the Baseline Configuration and Configuration with $100 \%$ Unidirectional Glass Replacement (Wind Load is $70 \mathrm{~m} / \mathrm{s} ; \mathrm{C}_{\mathrm{d}}$ is 1.7 ).

Bottom: Brick Element Numbering for Blade Element No. 7. 


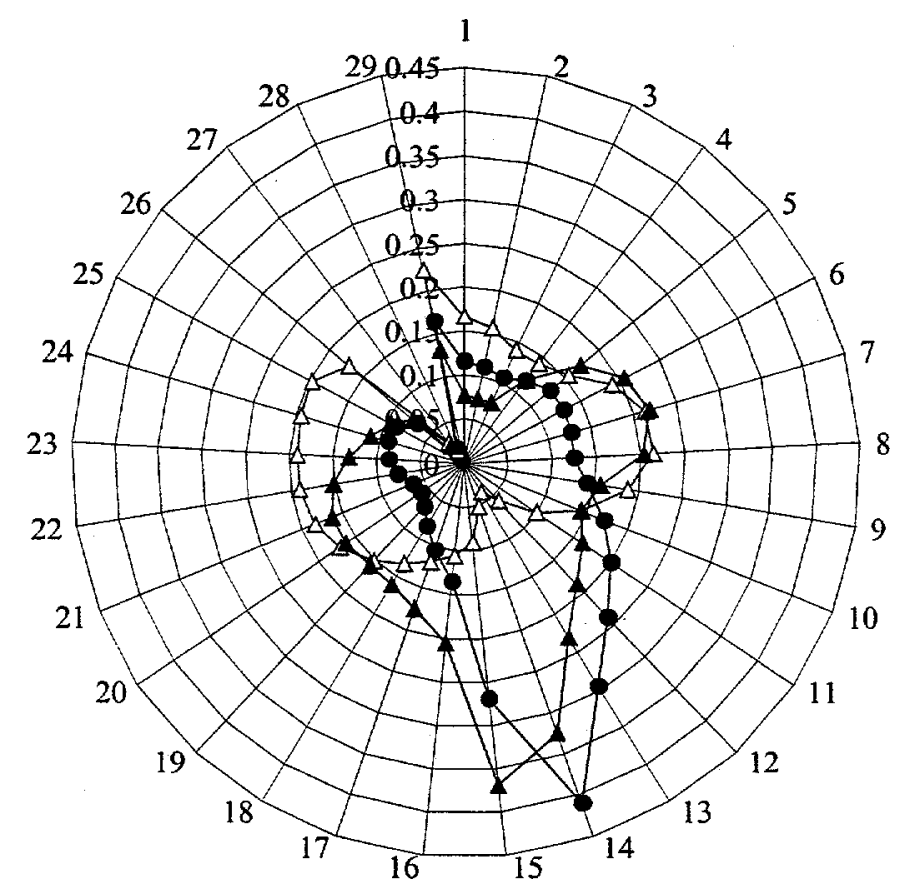

Element \# 8 (baseline) $\triangle-$ Element \# 8 (twist towards stall) $\rightarrow-$ Element \# 8 (twist towards feather)

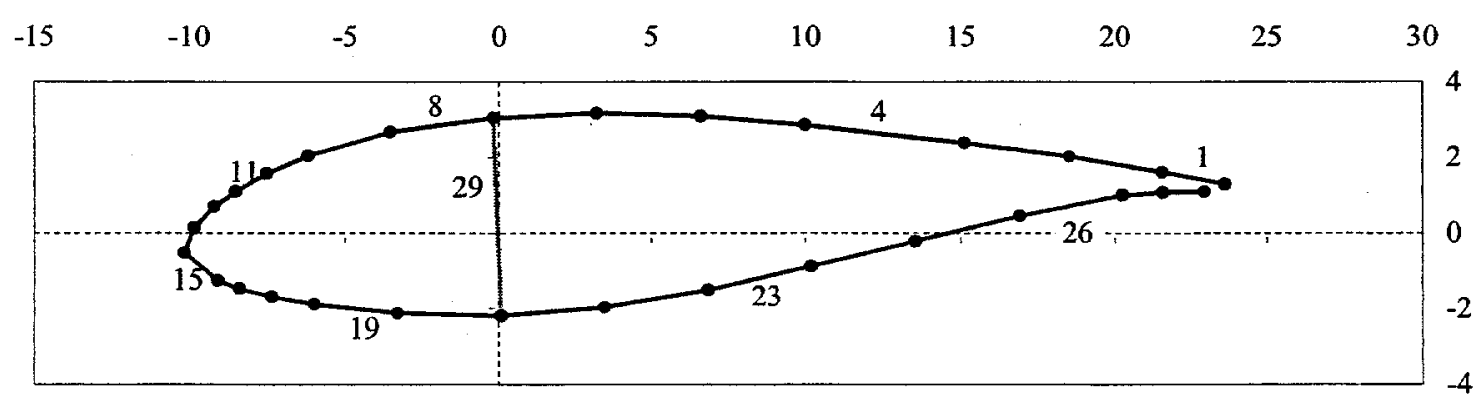

Figure 3.21 Top: Failure Index along the "Brick Elements" for Blade Element No. 8 (Station 168 - 192) for the Baseline Configuration and Configuration with $100 \%$ Unidirectional Glass Replacement (Wind Load is $70 \mathrm{~m} / \mathrm{s} ; C_{d}$ is 1.7 ).

Bottom: Brick Element Numbering for Blade Element No. 8. 


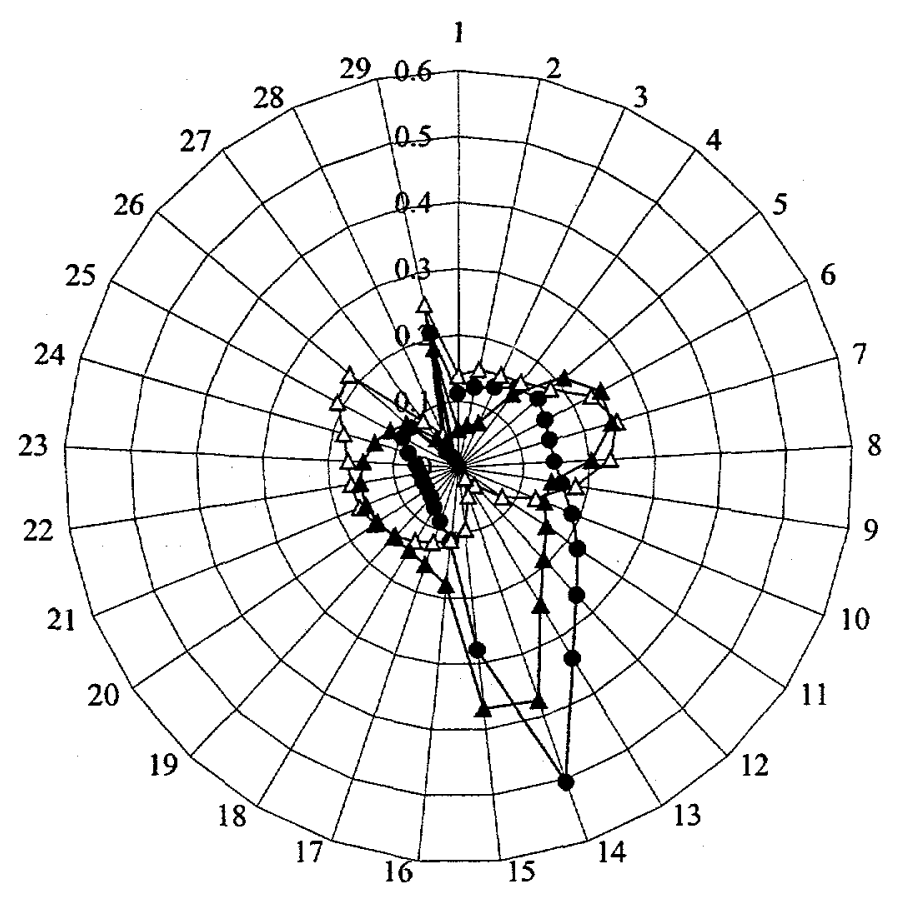

Element \# 9 (baseline) $\rightarrow-$ Element \# 9 (twist towards stall) $₫-$ Element \# 9 (twist towards feather)

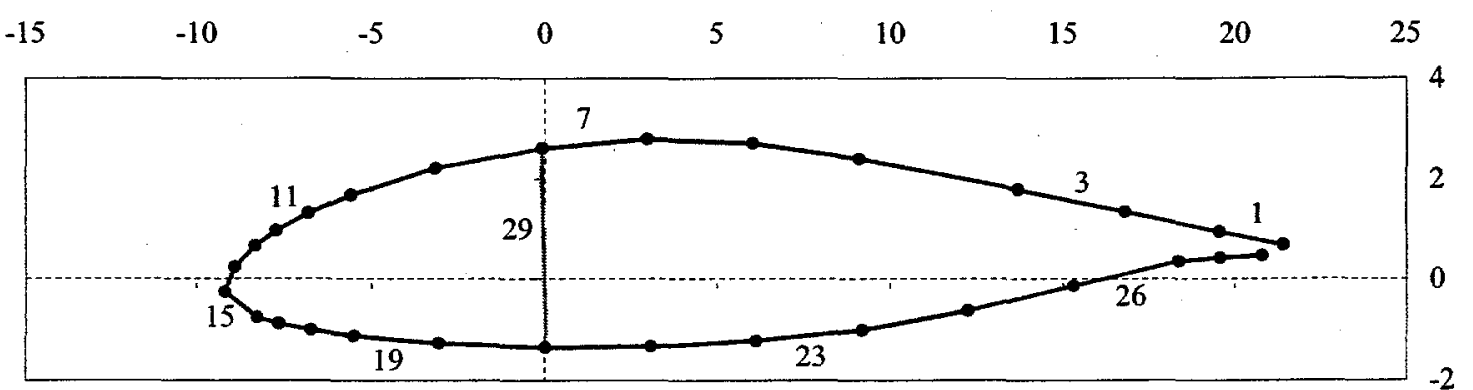

Figure 3.22 Top: Failure Index along the "Brick Elements" for Blade Element No. 9 (Station 192 - 216) for the Baseline Configuration and Configuration with $100 \%$ Unidirectional Glass Replacement (Wind Load is $70 \mathrm{~m} / \mathrm{s} ; \mathrm{C}_{\mathrm{d}}$ is 1.7 ).

Bottom: Brick Element Numbering for Blade Element No. 9. 

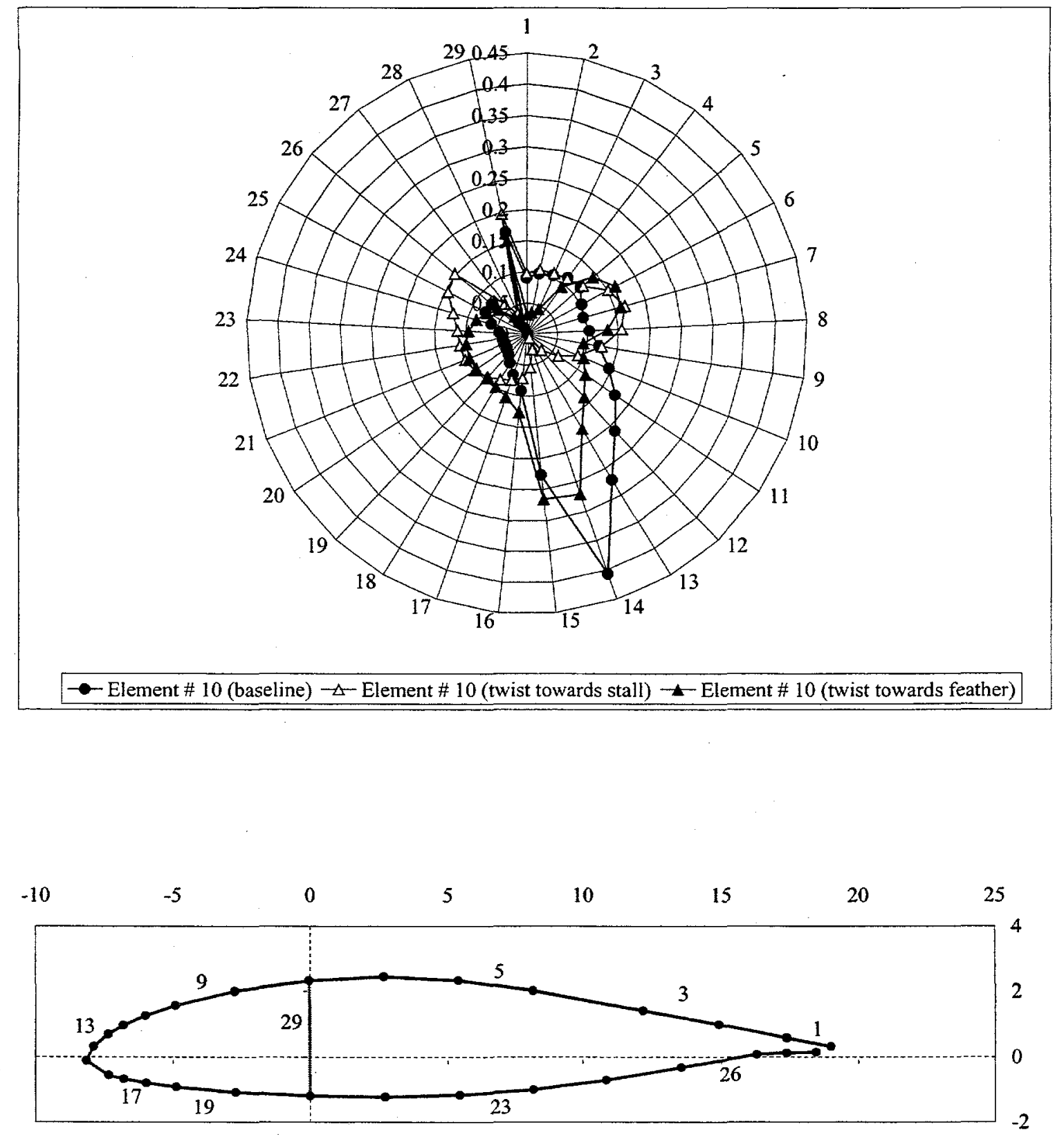

Figure 3.23 Top: Failure Index along the "Brick Elements" for Blade Element No. 10 (Station 216 - 240) for the Baseline Configuration and Configuration with $100 \%$ Unidirectional Glass Replacement (Wind Load is $70 \mathrm{~m} / \mathrm{s} ; \mathrm{C}_{d}$ is 1.7 ).

Bottom: $\quad$ Brick Element Numbering for Blade Element No. 10. 

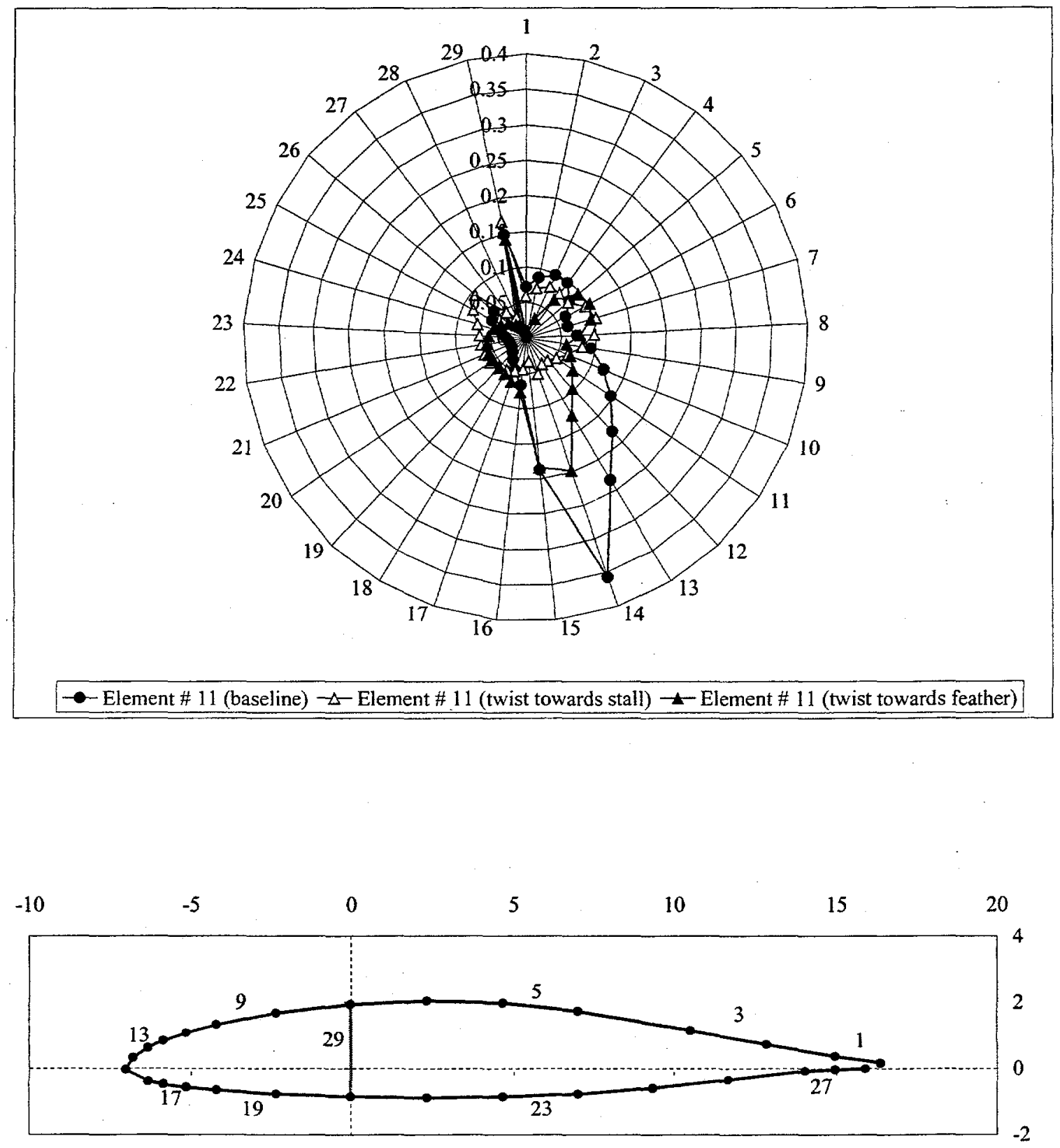

Figure 3.24 Top: Failure Index along the "Brick Elements" for Blade Element No. 11 (Station 240 - 264) for the Baseline Configuration and Configuration with $100 \%$ Unidirectional Glass Replacement (Wind Load is $70 \mathrm{~m} / \mathrm{s} ; C_{d}$ is 1.7 ).

Bottom: Brick Element Numbering for Blade Element No. 11. 

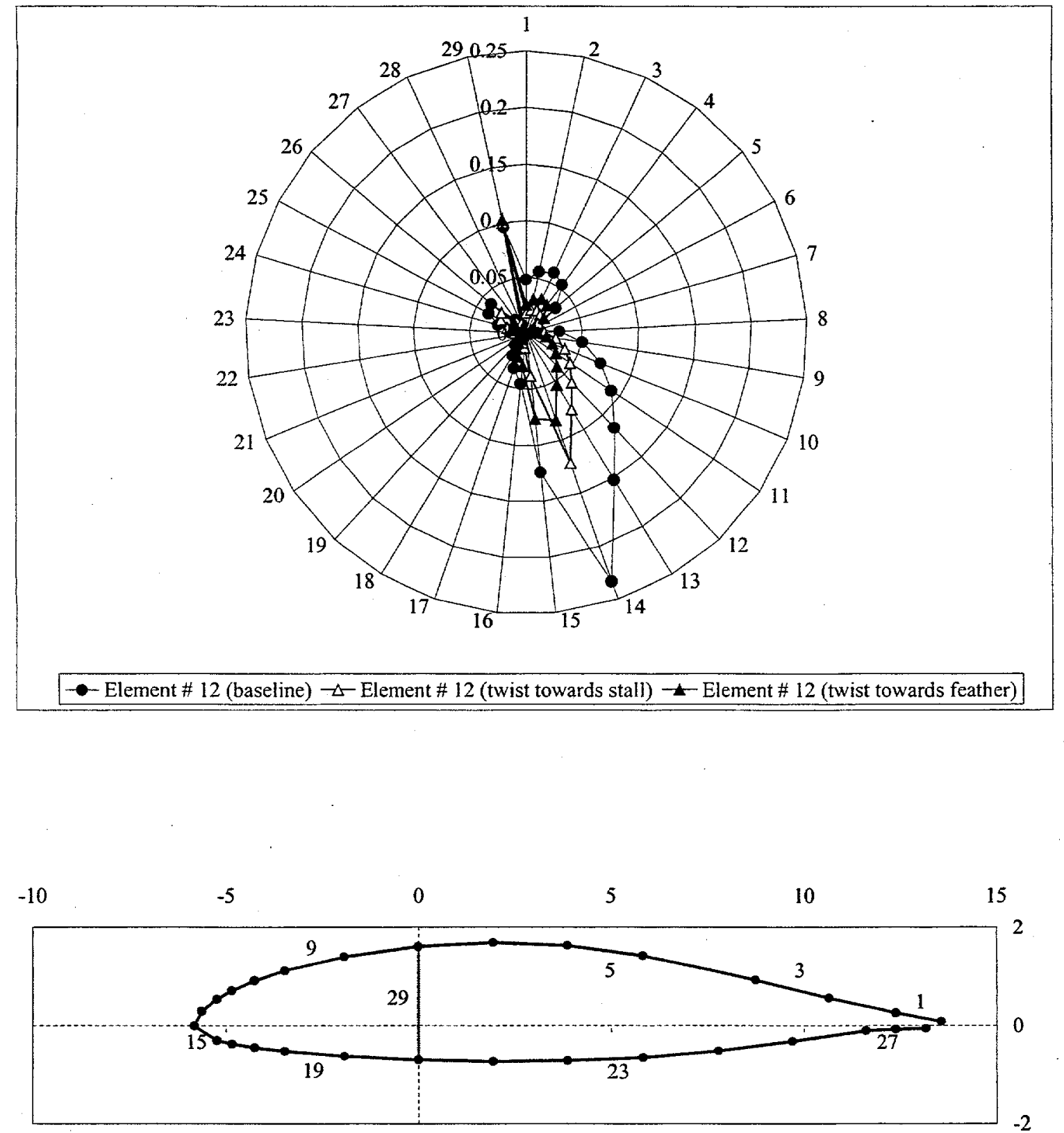

Figure 3.25 Top: Failure Index along the "Brick Elements" for Blade Element No. 12 (Station 264 - 288) for the Baseline Configuration and Configuration with $100 \%$ Unidirectional Glass Replacement (Wind Load is $70 \mathrm{~m} / \mathrm{s} ; \mathrm{C}_{d}$ is 1.7 ).

Bottom: Brick Element Numbering for Blade Element No. 12. 

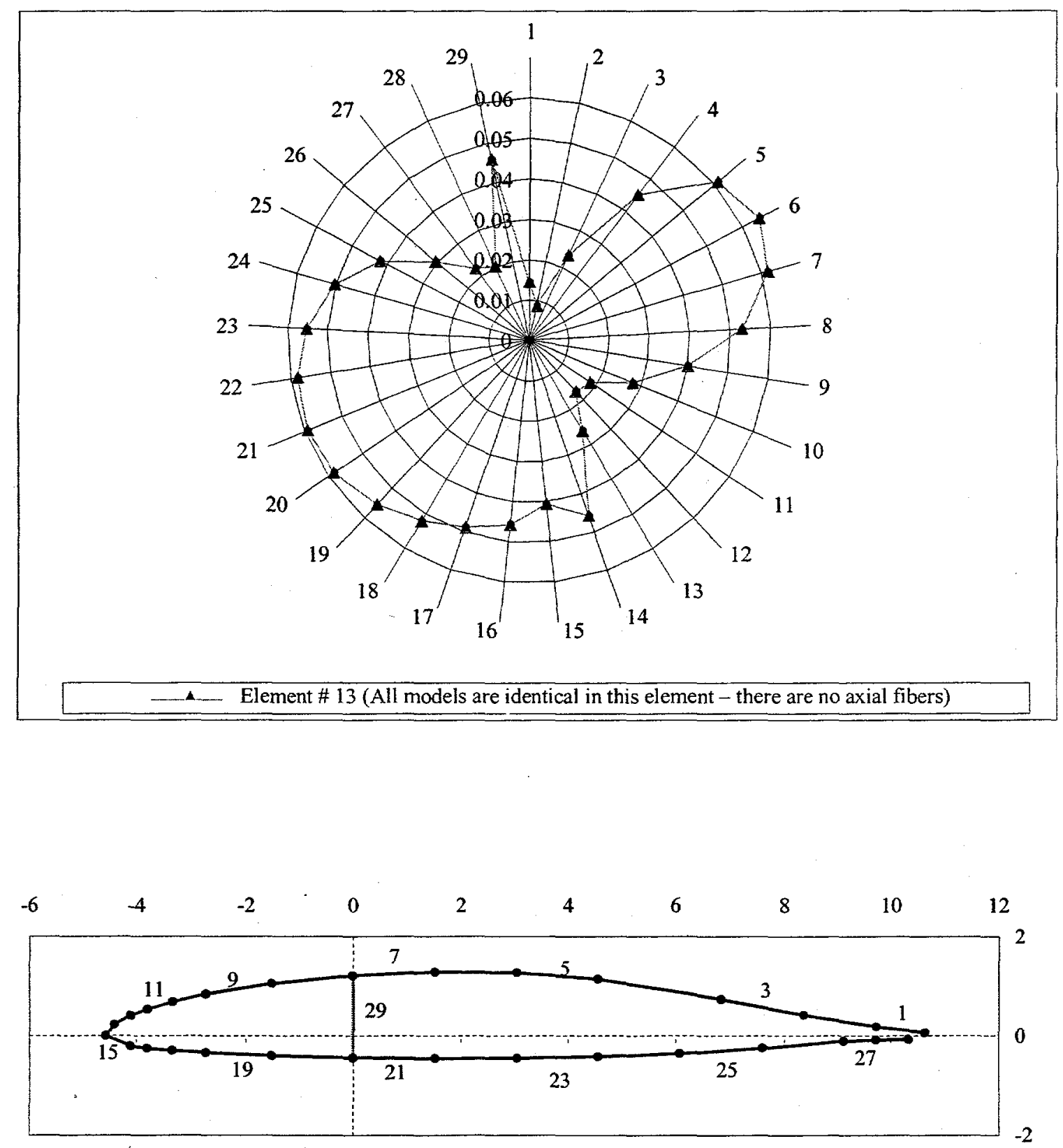

Figure 3.26 Top: Failure Index along the "Brick Elements" for Blade Element No. 13 (Station 288 - 312) for the Baseline Configuration, which is identical to the twist-coupled configurations at this element. (Wind Load is $70 \mathrm{~m} / \mathrm{s} ; C_{d}$ is 1.7 ).

Bottom: Brick Element Numbering for Blade Element No. 13. 


\section{Chapter 4}

\section{Cost Estimates for the SERI-8 Blade}

Cost has been a significant factor in composite designs and their manufacture. Cost reduction can be achieved by improving the design, manufacturing processes, equipment, and materials systems.

Glass fibers are the traditional basis material used in wind turbine blade design and manufacturing. As discussed in previous chapters, tremendous improvements in blade performance (such as reduction in weight, skin thickness, higher bend-twist coupling) can be achieved, if carbon fibers are introduced. However, carbon fibers generally cost at least ten times more than glass fibers. The perception that high material cost will lead to an increase in total cost keeps blade manufacturers from using carbon fibers. However, there is often a net cost savings in spite of the high carbon fiber material cost because the labor cost is reduced in laminating when fewer fibers are required.

In evaluating manufacturing costs for wind turbine blades, we looked at recurring costs, those associated with all elements in manufacturing a part. These costs are linked closely to design and manufacturing processes and provide criteria for evaluating cost effectiveness of these parameters. Recurring costs include factory fabrication labor, support labor functions for engineering, quality control, tooling, manufacturing engineering, and graphic services; production and support material; indirect charges such as labor and material overhead and general and administrative costs [8], illustrated in Figure 4.1. This particular recurring cost structure was developed by an aerospace manufacturer, Northrop Corporation, and so not all fabrication functions are applicable to blade manufacturing. We focus here on material cost and factory fabrication labor cost.

Factory fabrication labor is the direct effort required to transform raw material into the final composite part, and has four major steps: lay-up, core operation, part consolidation, and finishing.

In a comparison between glass composite and hybrid (carbon and glass fibers) composite, we looked at three cases: (a) material only for a general composite part, (b) 
material and labor costs for a general composite part, and (c) the estimate for a SERI-8 blade.

\subsection{Cost Estimate I (Materials Only)}

The criterion for comparing costs between a hybrid and glass composite is to maintain the same axial stiffness (it is easy to derive some ratio parameters using this criterion). We assume that glass fibers cost $\$ 1.2 / \mathrm{lb}$., carbon fibers cost $\$ 13 / \mathrm{lb}$, and the labor rate is assumed to be $\$ 65 /$ hour [9]. The material properties for glass and carbon prepreg materials are given in Table 2.1 and 3.1 respectively. Two important ratios, weight ratio and cost ratio, can be derived.

The weight ratio is defined as the weight of the hybrid composite divided by that of an all-glass composite. The weight ratio is given by

$$
\text { Weight_Ratio }=\frac{1+\mathrm{Vol}_{\mathrm{c} / \mathrm{g}} \bullet \mathrm{S}_{\mathrm{c}} / \mathrm{S}_{\mathrm{g}}}{1+\mathrm{Vol}_{\mathrm{c} / \mathrm{g}} \bullet \mathrm{E}_{\mathrm{c}} / \mathrm{E}_{\mathrm{g}}}
$$

The parameters in Equation (4.1) are defined as follows: S, specific gravity; E, axial modulus; subscript 'g', glass; subscript ' $c$ ', carbon; and $\mathrm{Vol}_{\mathrm{c} / \mathrm{g}}$, carbon/glass volume ratio.

The cost ratio is the ratio of the cost of the hybrid composite to the all-glass composite to provide the same axial stiffness. This is given by

$$
\text { Cost_Ratio_I }=\frac{1+\mathrm{Vol}_{\mathrm{c} / \mathrm{g}} \bullet \mathrm{S}_{\mathrm{c}} / \mathrm{S}_{\mathrm{g}} \cdot \mathrm{S}_{\mathrm{c}} / \$_{\mathrm{g}}}{1+\mathrm{Vol}_{\mathrm{c} / \mathrm{g}} \bullet \mathrm{E}_{\mathrm{c}} / \mathrm{E}_{\mathrm{g}}}
$$

The additional parameter, $\$$, is cost per unit weight.

The two variables in the cost and weight ratios are the volume ratio, $\mathrm{Vol}_{\mathrm{c} / \mathrm{g}}$, and material cost ratio. If we assume that the material cost ratio is about 10 to $1(\$ 13 / 1 b$ for carbon and $\$ 1.2 / \mathrm{lb}$ for glass), then we can tabulate both the cost ratio and weight ratio as a function of volume ratio of a hybrid composite (see Table 4.1). Thus, an all-carbon fiber composite costs 2.4 times more than an all-glass fiber composite to provide the same axial stiffness at a weight savings of $78 \%$. When a $50 / 50$ glass/carbon hybrid 
composite is used, however, the calculated cost ratio is about 2.1 and the weight savings is $62 \%$.

\subsection{Cost Estimate II (Material and Labor Costs)}

In Cost Estimate I, we assume no or negligible labor costs. This assumption ultimately limits the use of carbon fibers in any composite part design and fabrication if cost is the only design parameter. In fact, we can't produce any composite part without incurring labor costs, which are the labor hours required to produce a composite part and labor rate ( $\$$ /hour, $\$ 65 /$ hour is assumed here). The hours depend on the types of manufacturing processes involved. Processes such as pultrusion, filament winding and automatic tape layup reduce the recurring labor hours significantly, although capital investment is huge. Thus, one major strategy to reduce the cost of advanced composites is to automate the labor-intensive activities. In this discussion, we focus on the hand lay-up process, which dominates in blade manufacturing.

The cost ratio, which includes both material and labor costs, is the ratio of the cost of the hybrid composite to the all-glass composite with the same axial stiffness. It is given by

Cost_Ratio_II $=\frac{\mathrm{L}_{\mathrm{h}}+\mathrm{M}_{\mathrm{h}}}{\mathrm{L}_{\mathrm{g}}+\mathrm{Mg}}=\frac{\mathrm{L}_{\mathrm{h} / \mathrm{L}_{\mathrm{g}}} \cdot \mathrm{L}_{\mathrm{g}} / \mathrm{M}_{\mathrm{g}}+{ }^{\mathrm{M}_{\mathrm{h}} / \mathrm{M}_{\mathrm{g}}}}{\mathrm{L}_{\mathrm{g}} / \mathrm{M}_{\mathrm{g}}+1}$

The parameters in Equation (4.3) are defined as follows: L, labor cost; M, material cost; and subscript ' $\mathrm{h}$ ', hybrid composite. The ratio, $\mathrm{M}_{\mathrm{h}} / \mathrm{M}_{\mathrm{g}}$, is similar to the Cost_Ratio_I as defined in Equation (4.2). $\mathrm{L}_{\mathrm{g}} / \mathrm{M}_{\mathrm{g}}$ is the ratio of labor cost to the material cost of the all-glass composite. $\mathrm{L}_{\mathrm{h}} / \mathrm{L}_{\mathrm{g}}$ is the ratio of the labor cost of the hybrid composite to the all-glass composite to provide the same axial stiffness. In the hand lay-up process, the labor cost is a function of labor rate, lay-up hours per layer, and total number of layers of plies. We further assume that the labor rate and the lay-up hours per layer are the same regardless of the types of materials used, and that the thickness of the ply layers is equal for glass and carbon fibers (see Table 2.1). The labor cost ratio is then given by 


$$
\text { Labor_Cost_Ratio }=\frac{\mathrm{L}_{\mathrm{h}}}{\mathrm{L}_{\mathrm{g}}}=\frac{1+\mathrm{Vol}_{\mathrm{c} / \mathrm{g}}}{1+\mathrm{Vol}_{\cdot \mathrm{c} / \mathrm{g}} \bullet \mathrm{E}_{\mathrm{c}} / \mathrm{Eg}}
$$

If we substitute Equation (4.4) into (4.3), the two variables in the Cost_Ratio_II are the volume ratio, $\mathrm{Vol}_{\mathrm{c} / \mathrm{g}}$, and the labor/material cost ratio. We assume that the material cost ratio is about 10 to 1 ( $\$ 13 / \mathrm{lb}$ for carbon and $\$ 1.2 / \mathrm{lb}$ for glass); we tabulate a cost matrix in terms of volume ratio of the hybrid composite and labor/material cost ratio of the all-glass composite (see Table 4.2). Thus, an all-carbon fiber composite still costs 2.4 times more than an all-glass fiber composite when material cost is the only element to provide the same axial stiffness at a weight savings of $78 \%$. However, the all-carbon fiber composite will cost four times less than the all-glass fiber composite when labor cost is the only element. A cost savings (shown as italic print in Table 4.2) is achievable for a hybrid composite with any carbon/glass volume ratio if the labor cost is about $70 \%$ and the material cost is about $30 \%$ of the total (material and labor).

\subsection{Cost Estimate of SERI-8 Enhanced Blade Models}

Sections 4.1 and 4.2 described two simple methods to compare the cost ratio of a hybrid composite to an all-glass composite to maintain the same axial stiffness. The cost ratios are functions of parameters such as labor/material in the all-glass composite, the material in the hybrid composite and the all-glass composite, etc. The cost ratios do not reflect absolute production costs, which are driven by design, production volume, and how the process is run.

To estimate the absolute cost of the SERI- 8 blade, we utilized some functions of the cost model developed for advanced composites manufacturing for the aerospace industry by Northrop Corporation [8] for the Air Force. The cost structure for the model is shown in Figure 4.1; however, not all the elements are applicable to a blade manufacturing process. We used two elements, direct material cost and direct labor cost for factory fabrication, to evaluate the multiple design options for the SERI-8 enhanced models. As mentioned earlier, the factory fabrication process has four steps but because the SERI-8 models do not include core as one of the design variables, core operation is not evaluated here. Part consolidation and finishing costs, which are related to the size of 
the composite part, are applicable to all the SERI- 8 models, since all models have the same external dimensions.

The estimated factory labor hours to ensure various SERI-8 enhanced models have the same flapping stiffness for all models are shown in Figure 4.2. The estimated factory labor hour for the baseline all-glass model is about 400 hours, and the estimated factory labor hour for the configuration with $100 \%$ unidirectional fiber glass replacement to carbon fibers (about 65\% carbon content, see Table 4.3) is about 140 hours. The cost ratio reference to the baseline model is about 1 to 3 ; this ratio assumed that labor is the only element in total cost and assumed a fixed labor rate. The cost ratio (1/3) is close to the estimated value of 1/4, which is for an all-carbon composite using Equation 4.4.

We found out from TPI, a blade manufacturer, that their estimate of labor hour would be about 40 hours. In order to reflect TPI's estimated hours for fabricating a blade, we scaled the estimated lay-up hours by a factor of 10 for the baseline and all enhanced models. The scaling results in reduction of factory labor for the all-glass SERI- 8 blade from 400 hours to 45 hours (there is no scaling applied to the hours for consolidation and finish operations), which is close to TPI's estimate. Although the labor scaling does not affect the cost ratio, it affects the ratio of labor cost to material cost. Before the adjustment, the labor for the all-glass SERI-8 blade (baseline model) was the major cost as compared to the material cost. Thus, we see a huge cost reduction for all SERI-8 enhanced models, as shown in Figure 4.4. The adjustment effectively reduces the labor cost by a factor of 10 and makes material a significant cost parameter. Consequently, not all enhanced models reduce fabrication cost. The enhanced models that cost less than the all-glass model have less than 15\% volume of carbon (see Table 4.3 and Figure 4.5 ) in the blade design.

In private correspondence with James Tangler, the originator of the SERI blade series, we obtained some previously unpublished blade-cost information. The information shown in Table 4.4, is for fabricating a SERI 9.7 meter blade, which is very similar to the SERI-8 blade. Tangler indicated that the cost ratio of labor to material for an all-glass blade should be about 50/50 (for SERI-9.7 meter blade, the ratio is about $40 / 60$ as shown in Table 4.4). Therefore, there is no cost advantage for carbon fibers in a blade design with this labor to material cost ratio, as indicated in Table 4.2. Tangler also stated that the 
labor hours were 84 hours. He does not have an exact labor rate but his reasonable guess would be about $\$ 10$ an hour which results in about 84 hours of labor. We used labor rate of $\$ 65 /$ hour [9] in the cost study. If a labor rate of $\$ 65 /$ hour were used for the estimate, the cost ratio of labor to material for the SERI 9.7 meter blade would be $80 / 20$; and we would have different deduction on cost advantage of fabrication of a hybrid blade.

In summary, labor and materials are two main elements in total cost. The proportion of labor to material in the total cost affects the volume of carbon fibers allowed in a wind turbine blade design if cost is the only design variable. 
Table 4.1 The Ratios of Carbon-Enhanced/Baseline Blade Weight and Cost as a Function of Volume Ratio of Glass and Carbon when only Material Costs are Considered

\begin{tabular}{|c|c|c|c|}
\hline Glass_Vol./Carbon_Vol. & Weight_Ratio & Weight_Saving & Cost_Ratio \\
\hline $0 / 100$ & 0.22 & $77.8 \%$ & 2.41 \\
\hline $10 / 90$ & 0.24 & $75.7 \%$ & 2.37 \\
\hline $20 / 80$ & 0.27 & $73.2 \%$ & 2.32 \\
\hline $30 / 70$ & 0.30 & $70.3 \%$ & 2.27 \\
\hline $40 / 60$ & 0.33 & $66.7 \%$ & 2.21 \\
\hline $50 / 50$ & 0.38 & $62.2 \%$ & 2.13 \\
\hline $60 / 40$ & 0.43 & $56.6 \%$ & 2.02 \\
\hline $70 / 30$ & 0.51 & $49.1 \%$ & 1.89 \\
\hline $80 / 20$ & 0.61 & $38.9 \%$ & 1.70 \\
\hline $90 / 10$ & 0.76 & $23.9 \%$ & 1.43 \\
\hline $100 / 0$ & 1.00 & $0.0 \%$ & 1.00 \\
\hline
\end{tabular}


Table 4.2 Estimated Total Cost Ratios for a Matrix of Labor/Material Cost Splits and Glass/Carbon Fiber Content

\begin{tabular}{|c|c|c|c|c|c|c|c|c|c|c|c|c|}
\hline & & \multicolumn{11}{|c|}{ Glass_Vol. / Carbon_Vol. } \\
\hline & & $100 / 0$ & $90 / 10$ & $80 / 20$ & $70 / 30$ & $60 / 40$ & $50 / 50$ & $40 / 60$ & $30 / 70$ & $20 / 80$ & $10 / 90$ & $0 / 100$ \\
\hline \multirow{11}{*}{ 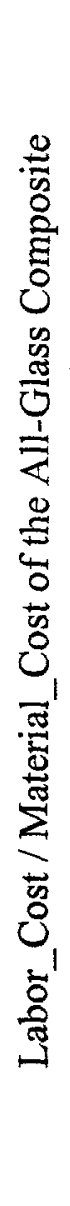 } & $0 / 100$ & 1.00 & 1.43 & 1.70 & 1.89 & 2.02 & 2.13 & 2.21 & 2.27 & 2.32 & 2.37 & 2.41 \\
\hline & $10 / 90$ & 1.00 & 1.37 & 1.60 & 1.75 & 1.87 & 1.95 & 2.02 & 2.08 & 2.12 & 2.16 & 2.19 \\
\hline & $20 / 80$ & 1.00 & 1.30 & 1.49 & 1.62 & 1.71 & 1.78 & 1.84 & 1.88 & 1.92 & 1.95 & 1.98 \\
\hline & $30 / 70$ & 1.00 & 1.23 & 1.38 & 1.48 & 1.55 & 1.61 & 1.65 & 1.69 & 1.72 & 1.74 & 1.76 \\
\hline & $40 / 60$ & 1.00 & 1.17 & 1.27 & 1.34 & 1.40 & 1.44 & 1.47 & 1.49 & 1.51 & 1.53 & 1.54 \\
\hline & $50 / 50$ & 1.00 & 1.10 & 1.16 & 1.21 & 1.24 & 1.26 & 1.28 & 1.30 & 1.31 & 1.32 & 1.33 \\
\hline & $60 / 40$ & 1.00 & 1.03 & 1.06 & 1.07 & 1.08 & 1.09 & 1.10 & 1.10 & 1.11 & 1.11 & 1.11 \\
\hline & $70 / 30$ & 1.00 & 0.97 & 0.95 & 0.94 & 0.93 & 0.92 & 0.91 & 0.91 & 0.90 & 0.90 & 0.90 \\
\hline & $80 / 20$ & 1.00 & 0.90 & 0.84 & 0.80 & 0.77 & 0.75 & 0.73 & 0.71 & 0.70 & 0.69 & 0.68 \\
\hline & $90 / 10$ & 1.00 & 0.84 & 0.73 & 0.66 & 0.61 & 0.57 & 0.54 & 0.52 & 0.50 & 0.48 & 0.47 \\
\hline & $100 / 0$ & 1.00 & 0.77 & 0.63 & 0.53 & 0.45 & 0.40 & 0.36 & 0.32 & 0.29 & 0.27 & 0.25 \\
\hline
\end{tabular}


Table 4.3 Averaged Volume of Carbon Fibers in Various SERI-8 Enhanced Models

\begin{tabular}{|c|c|l|}
\hline SERI-8 Enhanced Models & Averaged Carbon Volume & Remarks \\
\hline $\begin{array}{c}20 \% \text { Unidirectional Glass } \\
\text { Fiber Replacement }\end{array}$ & $5 \%$ & Reference to Table 3.2 \\
\hline $\begin{array}{c}40 \% \text { Unidirectional Glass } \\
\text { Fiber Replacement }\end{array}$ & $14 \%$ & Reference to Table 3.3 \\
\hline $\begin{array}{c}60 \% \text { Unidirectional Glass } \\
\text { Fiber Replacement }\end{array}$ & $25 \%$ & Reference to Table 3.4 \\
\hline $\begin{array}{c}80 \% \text { Unidirectional Glass } \\
\text { Fiber Replacement }\end{array}$ & $40 \%$ & Reference to Table 3.5 \\
\hline $\begin{array}{c}100 \% \text { Unidirectional Glass } \\
\text { Fiber Replacement }\end{array}$ & $65 \%$ & Reference to Table 3.6 \\
\hline
\end{tabular}


Table 4.4 Breakdown of Cost Elements of a SERI 9.7-meter Blade

\begin{tabular}{|l|c|}
\hline \multicolumn{1}{|c|}{ Description } & Cost \\
\hline Labor & $\$ 840$ \\
\hline Raw Materials (fibers and resin) & $\$ 1200$ \\
\hline Flanges and Root Units & $\$ 800$ \\
\hline Spoiler Tip Mechanism & $\$ 1000$ \\
\hline Overhead & $\$ 875$ \\
\hline \multicolumn{2}{r|}{ Total } \\
\cline { 2 - 3 }
\end{tabular}




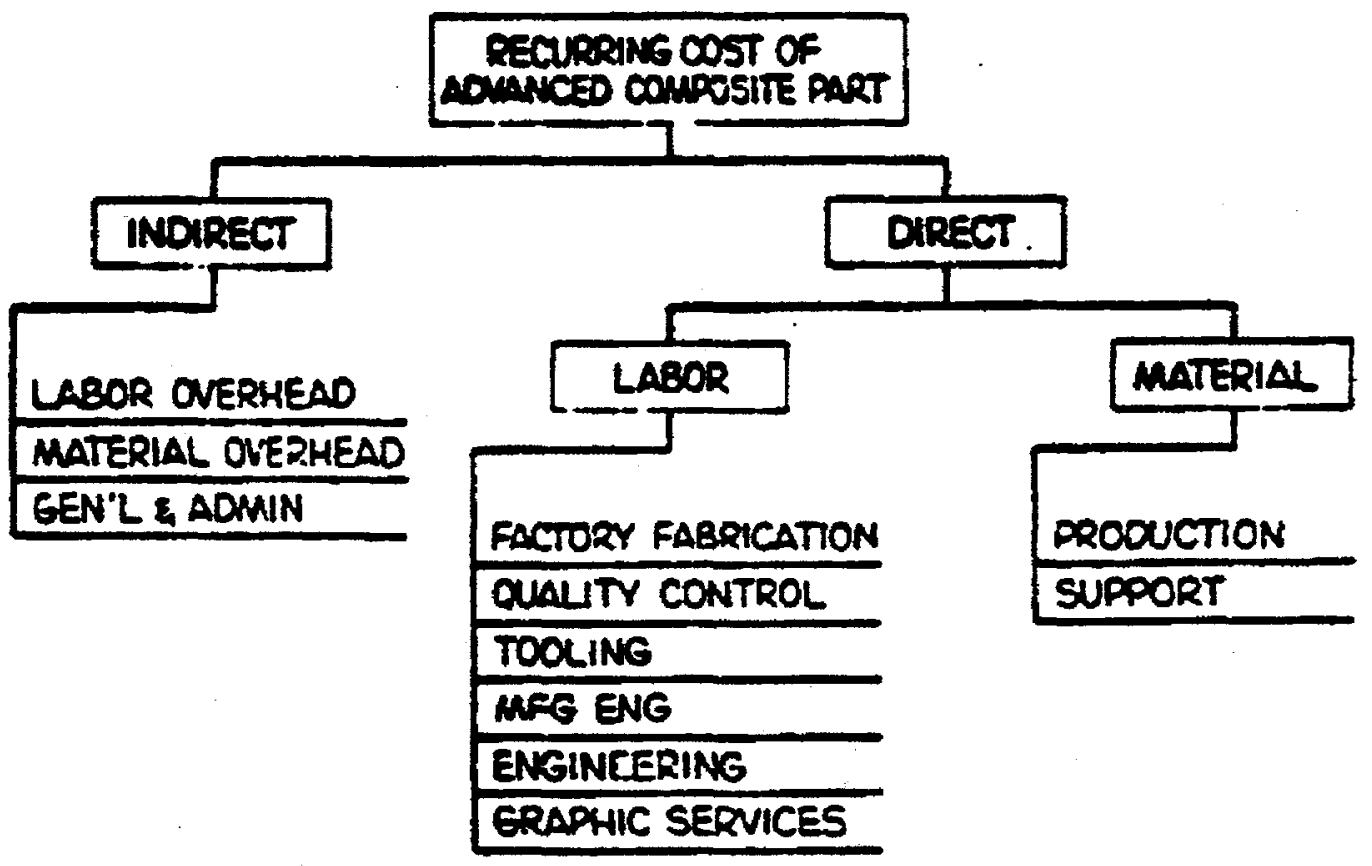

Figure 4.1 Recurring Cost of Advanced Composite Part [8] 


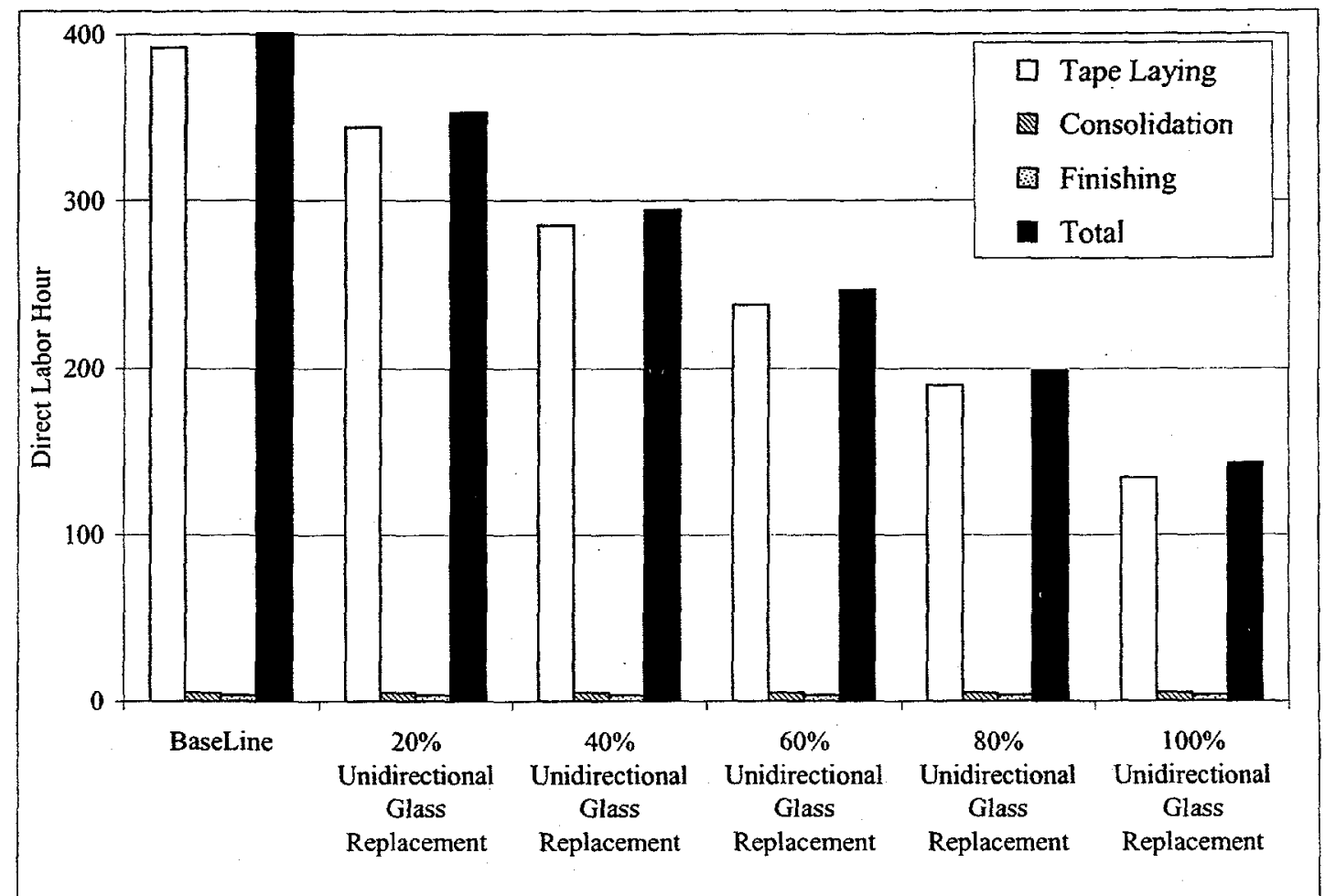

Figure 4.2 Factory Labor Hours for Various SERI-8 Enhanced Model Configurations Estimated by Northrop's Model [8]

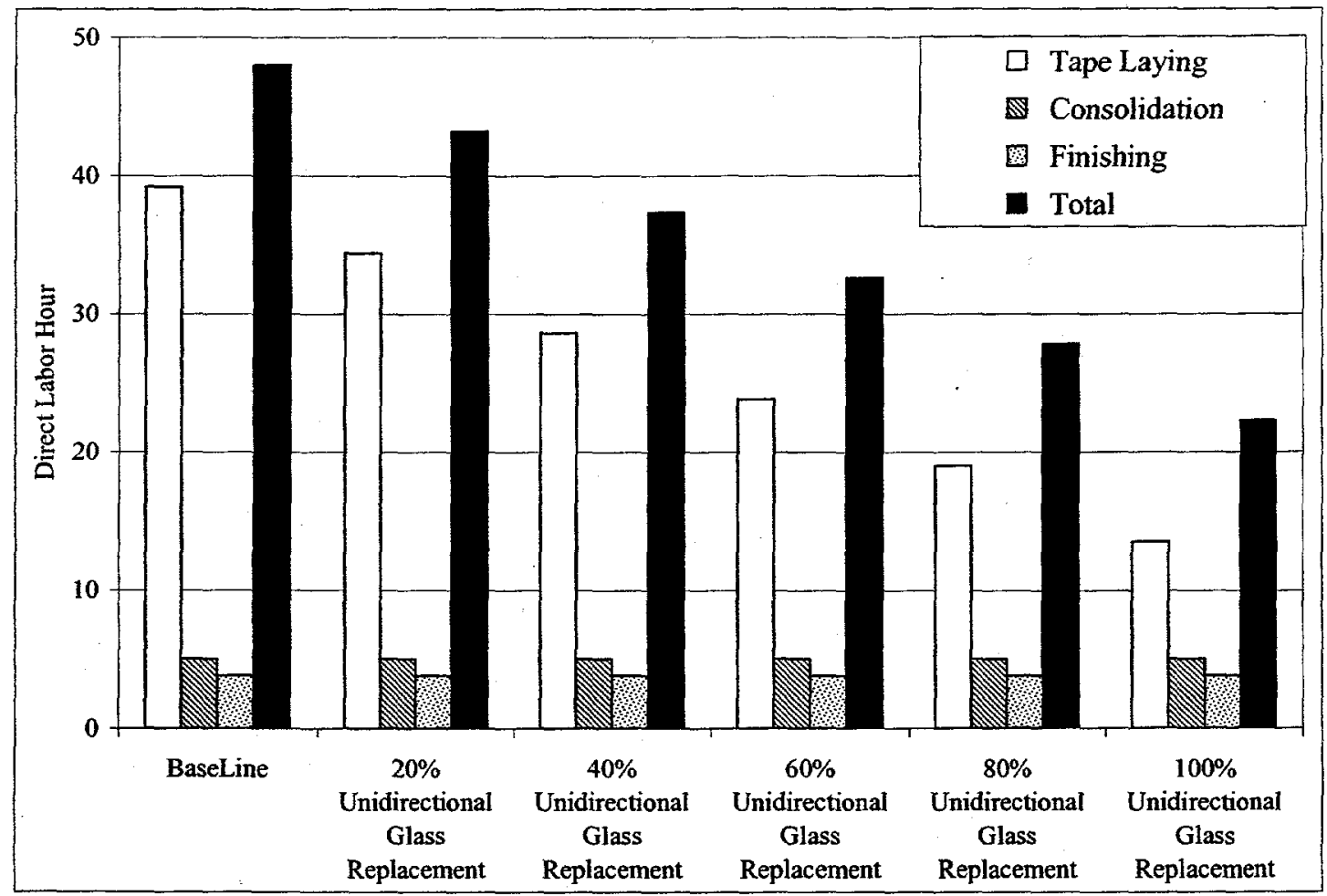

Figure 4.3 Scaled Factory Labor Hours for Various SERI-8 Enhanced Model Configurations after Applying Scale Factor of 10 to Layup Hours to Reflect TPIs Blade Fabrication Hours for All-Glass Blade 


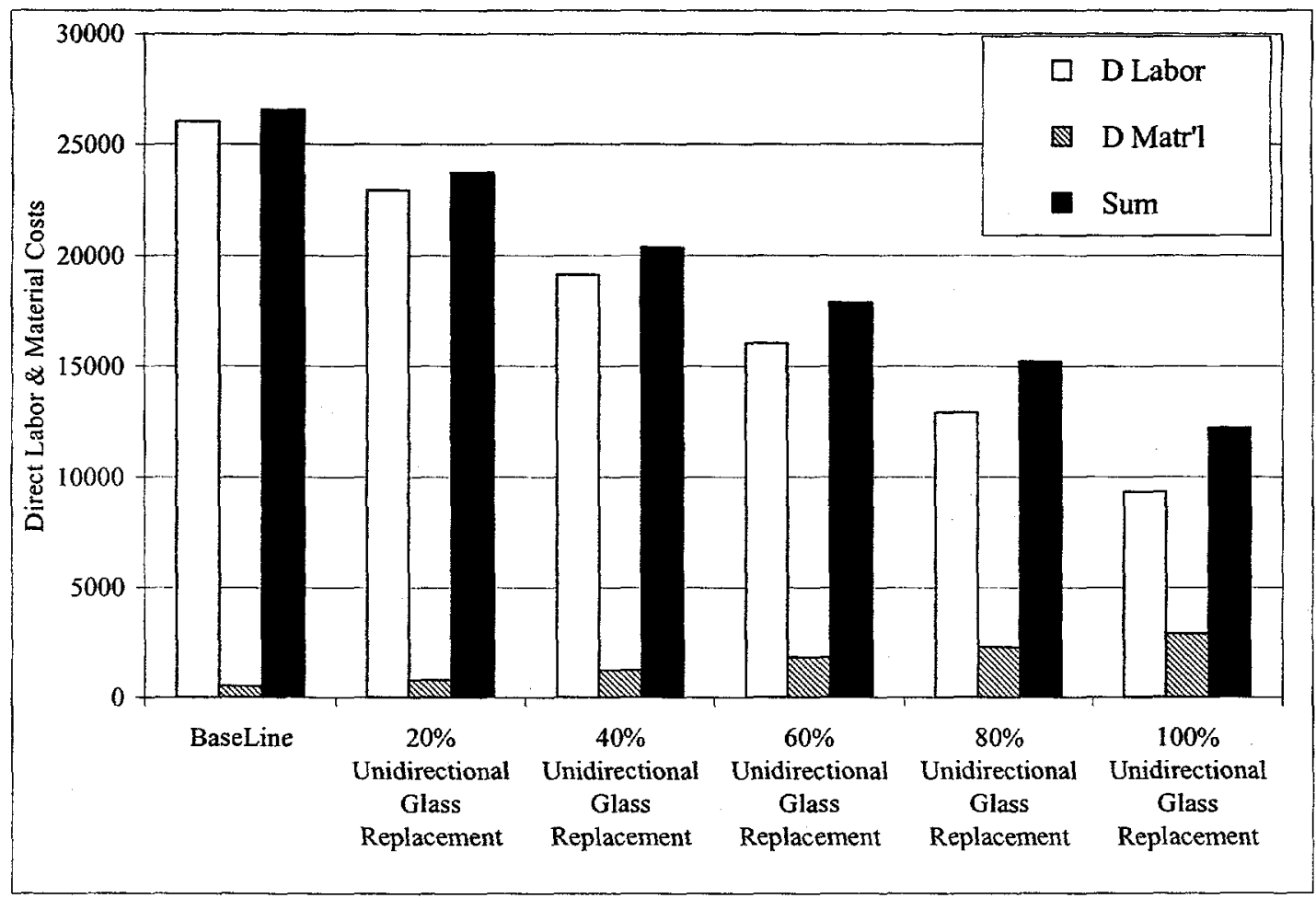

Figure 4.4 Factory Labor, Material and Total Costs for Various SERI-8 Enhanced Model Configurations Based Only on the Northrop Model

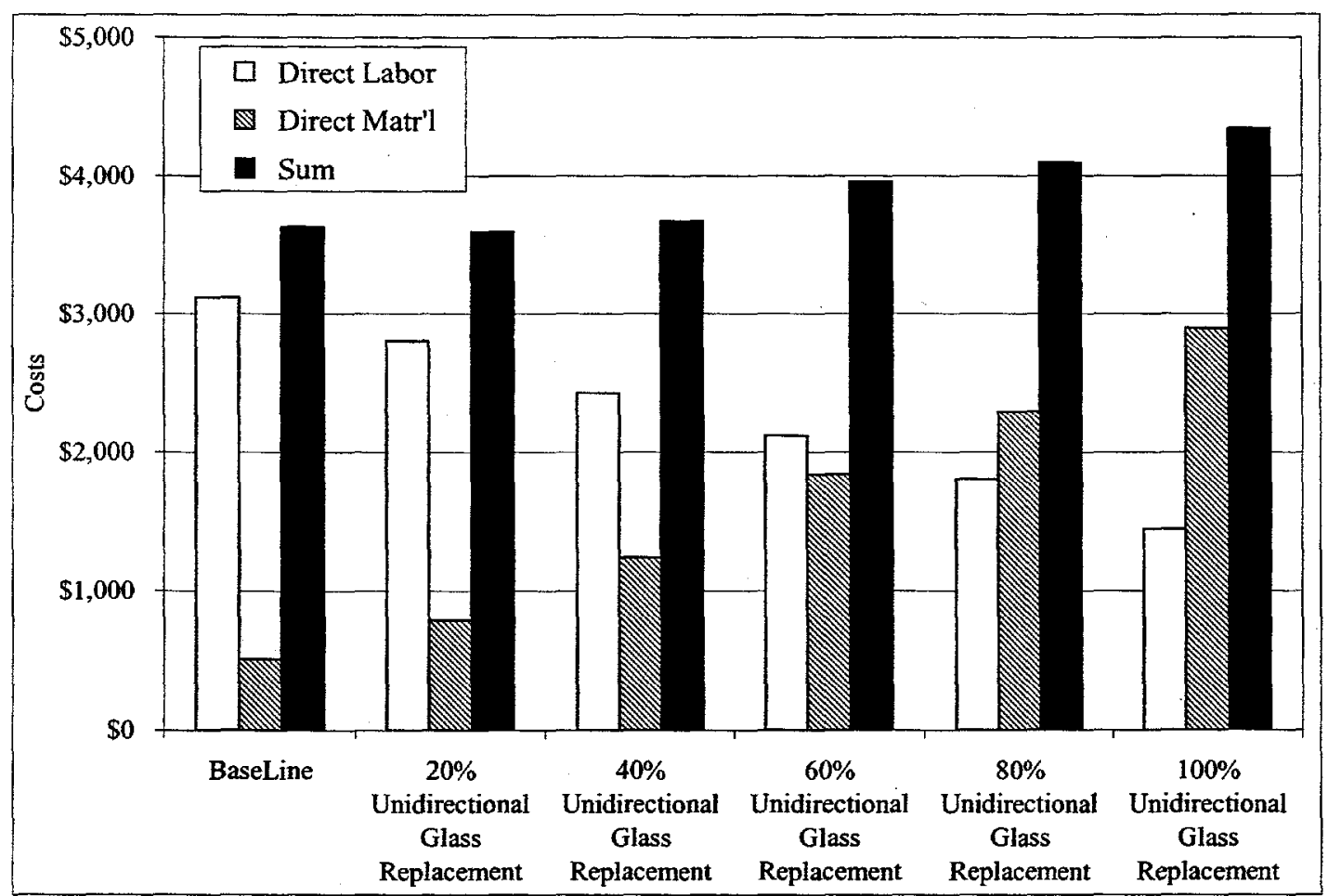

Figure 4.5 Factory Labor, Material and Total Costs for Various SERI-8 Enhanced Model Configurations after Applying Scale Factor of 10 to Layup Hours to Reflect TPI's Blade Fabrication Hours for All-Glass Blade 


\section{Chapter 5}

\section{Conclusions}

We generated a baseline model of the SERI-8 blade validated it against an available database and test results. The validation is satisfactory. Enhanced models that incrementally replaced unidirectional glass fibers with carbon fibers were designed to study the cost and structural performance if carbon fibers were used in wind turbine blade design. The criterion used for all the enhanced models, which have options with and without bend-twist-coupled design, was to have the same flapping stiffness as the baseline model. The study indicates that increased use of carbon fibers in blade design improves blade performance because of reducing weight and skin thickness. A factor of safety of 2 is still achieved for an enhanced model with all unidirectional glass fibers replaced by $20^{\circ}$ off-axis carbon fibers subjected to severe wind speed of 70 meters/second.

In this study, a hand lay-up process was chosen to evaluate a cost comparison between the hybrid blade and the all-glass blade. If material is the sole element used in total cost, it is expensive to produce an all-carbon blade. However, in the other extreme where labor is the main element, there is tremendous savings in using carbon fibers in blade design. Northrop's model for the SERI-8 blade, after applying a scale factor of 10 to the lay-up hours to be close to the labor hours estimated by TPI, indicates that the cost of some enhanced models is comparable to that of the all-glass model. For the specific design and manufacturing assumptions in this study, cost savings is achievable if the carbon volume is less than $15 \%$ (Figure 4.5). In general, the cost advantage or disadvantage of carbon fiber replacement will depend on the cost ratio of labor to materials as shown in Table 4.2. It was assumed that labor costs are proportional to the number of layers of plies and that glass and carbon laminate thickness are equal (Table 2.1). Generic conclusions can therefore not be drawn because of this dependence on the 
specifics of the design and manufacturing process. However, sufficient data are provided here to estimate the potential for carbon fibers use in a specific blade manufacturing application. 


\section{References}

1. J. Tangler, B. Smith, D. Jager, T. Olsen, "SERI Thin Airfoil Blade Atmospheric Performance Test: Final Results," Windpower '90 Proceedings, Washington D.C., September 1990, pp. 118-125.

2. Bob Keller \& Brian Smith, SERI 7.9 meter Thin Airfoil Blade Pitch Data Sheet, Solar Energy Research Institute; Golden, Colorado, April 1990.

3. Kevin Jackson, SERI 8 Meter Advanced Technology Wind Turbine Blade, HL-918129-1, Dynamic Design, Davis, California, 1989.

4. Scott M. Klingenstein, "Analytical Prediction and Experimental Verification of Blade Loads Experienced by Two, Three-Bladed, Fixed Pitch, Horizontal Axis Wind Turbines," Master Thesis, University of North Dakota, 1989.

5. S. Sinh, Composite Blade Model and Software, XAF-4-14076-01, Stanford University, September 1997.

6. Phil Mosher, Data Sheets from TPI on glass/epoxy, Tillison Pearson Incorporated, Warren, Rode Island, January 20, 1999.

7. C.H. Ong \& S.W. Tsai, Design, Manufacture and Testing of A Bend-Twist D-spar, SAND99-1324, Sandia National Laboratories, Albuquerque, New Mexico, June 1999.

8. Donald J. LeBlanc, Advanced Composites Cost Estimating Manual (ACCEM), AFFDL-TR-76-87, Northrop Corporation, Hawthorne, California, August 1976.

9. Timothy G. Gutowski, Advanced Composites Manufacturing, New York, John Wiley \& Sons, Inc., 1997. 


\section{DISTRIBUTION}

T. Almeida

TPI Inc.

225 Alexander Road

Portsmouth, RI 02871

H. Ashley

Dept. of Aeronautics and

Astronautics Mechanical Engr.

Stanford University

Stanford, CA 94305

B. Bell

Zond Energy Systems Inc.

13681 Chantico Road

P.O. Box 1970

Tehachapi, CA 93561

C. P. Butterfield

NREL

1617 Cole Boulevard

Golden, CO 80401

G. Bywaters

Northern Power Technology Co.

Box 999

Waitsfield,VT 05673

J. Cadogan

U.S. Department of Energy

Office of Geothermal \& Wind

Technology

EE-12

1000 Independence Avenue SW

Washington, DC 20585

D. Caims

Montana State University

Mechanical \& Industrial Engineering Dept.

Bozeman, MT 59717

S. Calvert

U.S. Department of Energy

Office of Geothermal \& Wind

Technology

EE-12

1000 Independence Avenue SW

Washington, DC 20585

J. Chapman

OEM Development Corp.

840 Summer St.

Boston, MA 02127-1533
C. Christenson

Zond Energy Systems Inc.

13681 Chantico Road

PO Box 19070

Tehachapi, CA 93561

R. N. Clark

USDA

Agricultural Research Service

P.O. Drawer 10

Bushland, TX 79012

J. Cohen

Princeton Economic Research, Inc.

1700 Rockville Pike

Suite 550

Rockville, MD 20852

C. Coleman

Northern Power Technology Co.

Box 999

Waitsfield, VT 05673

K. J. Deering

The Wind Turbine Company

515 116th Avenue NE

No. 263

Bellevue, WA 98004

A. J. Eggers, Jr.

RANN, Inc.

744 San Antonio Road, Ste. 26

Palo Alto, CA 94303

P. R. Goldman

Director

Office of Geothermal and

Wind Technology

EE-12

U.S. Department of Energy

1000 Independence Avenue

Washington, DC 20585

G. Gregorek

Aeronautical \& Astronautical Dept.

Ohio State University

2300 West Case Road

Columbus, $\mathrm{OH} 43220$

C. Hansen

Windward Engineering

4661 Holly Lane

Salt Lake City, UT 84117 
C. Hiel

W. Brandt Goldsworthy \& Assoc. 23930-40 Madison Street

Torrance, CA 90505

S. Hock

Wind Energy Program

NREL

1617 Cole Boulevard

Golden, CO 80401

K. Jackson

Dynamic Design

123 C Street

Davis, CA 95616

G. James

University of Houston

Dept. of Mechanical Engineering 4800 Calhoun

Houston, TX 77204-4792

M. Kramer

Foam Matrix, Inc.

PO Box 6394

Malibu, CA 90264

A. Lucero

Librarian

National Atomic Museum

Albuquerque, NM 87185

R. Lynette

Springtyme Co.

212 Jamestown Beach Lane

Sequim, WA 98382

D. Malcolm

Global Energy Concepts, LLC

5729 Lakeview Drive NE

Suite 100

Kirkland, WA 98033

\section{J. F. Mandell}

Montana State University

302 Cableigh Hall

Bozeman, MT 59717

T. McCoy

Global Energy Concepts, LLC

5729 Lakeview Drive NE

Suite 100

Kirkland, WA 98033
R. N. Meroney

Dept. of Civil Engineering

Colorado State University

Fort Collins, CO 80521

P. Migliore

NREL

1617 Cole Boulevard

Golden, CO 80401

A. Mikhail

Zond Energy Systems, Inc.

13681 Chantico Road

PO Box 1970

Tehachapi, CA 93561

E. Moroz

Zond Energy Systems, Inc.

13681 Chantico Road

PO Box 1970

Tehachapi, CA 93561

W. Musial

NREL

1617 Cole Boulevard

Golden, CO 80401

NWTC Library (5)

NREL

1617 Cole Boulevard

Golden, CO 80401

V. Nelson

Department of Physics

West Texas State University

WT P.O. Box 60248

Canyon, TX 79016

Cheng-Huat Ong

Stanford University

Dept. of Aeronautics \& Astronautics

Stanford CA 94305-4035

L. Pratsch

U.S. Department of Energy

Office of Geothermal \& Wind Technology

EE-12

1000 Independence Avenue SW

Washington, DC 20585

R. G. Rajagopalan Aerospace Engineering Department

Iowa State University

404 Town Engineering Bldg.

Ames, IA 50011 
Michael Robinson

NREL

1617 Cole Boulevard

Golden, CO 80401

D. Sanchez

U.S. Dept. of Energy

Albuquerque Operations Office

P.O. Box 5400

Albuquerque, NM 87185

L. Schienbein

CWT Technologies, Inc.

4006 S. Morain Loop

Kennewick, WA 99337

R. Sherwin

Atlantic Orient

PO Box 1097

Norwich, VT 05055

Brian Smith

NREL

1617 Cole Boulevard

Golden, CO 80401

K. Starcher

AEI

West Texas State University

WT P.O. Box 60248

Canyon, TX 79016

\section{F. S. Stoddard}

Dynamic Design

P.O. Box 1373

Amherst, MA 01004

A. Swift

University of Texas at El Paso

Department of Mech. \& Ind. Engineering

El Paso, TX 79968

R. W. Thresher

NREL

1617 Cole Boulevard

Golden, CO 80401

S. Tsai

Stanford University

Dept. of Aeronautics \& Astronautics

Stanford University

Stanford, CA 94305-4035
W. A. Vachon

W. A. Vachon \& Associates

P.O. Box 149

Manchester, MA 01944

B. Vick

USDA, Agricultural Research Service

P.O. Drawer 10

Bushland, TX 79012

L. Wendell

2728 Enterprise Dr.

Richland, WA 99352

R. E. Wilson

Mechanical Engineering Dept.

Oregon State University

Corvallis, OR 97331

S. R. Winterstein

Civil Engineering Department

Stanford University

Stanford, CA 94305

M. Zuteck

MDZ Consulting

931 Grove Street

Kemah, TX 77565 
M.S. 0555

M.S. 0557

M.S. 0557

M.S. 0708

M.S. 0708

M.S. 0708

M.S. 0708

M.S. 0708

M.S. 0708

M.S. 0708

M.S. 0708

M.S. 0708

M.S. 0847

M.S. 0847

M.S. 0612

M.S. 0899

M.S. 9018
B. Hansche, 9122

T. J. Baca, 9125

T. G. Carne, 9124

H. M. Dodd, 6214 (25)

T. D. Ashwill, 6214

D. E. Berg, 6214

P. L. Jones 6214

D. L. Laird, 6214

M. A. Rumsey, 6214

H. J. Sutherland, 6214

P. S. Veers, 6214

J. R. Zayas, 6214

D. W. Lobitz, 9125

D. R. Martinez, 9124

Review \& Approval Desk, 4912

Technical Library, 4916

(2)

Central Technical Files, 8940-2 